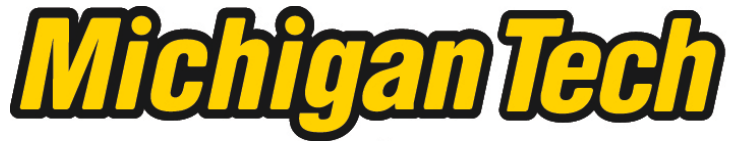 \\ Michigan Technological University Create the Future Digital Commons @ Michigan Tech
}

Dissertations, Master's Theses and Master's Reports - Open

Dissertations, Master's Theses and Master's

Reports

2010

\section{Post-project assessment and follow-up support for community managed rural water systems in Panama}

Ryu Suzuki

Michigan Technological University

Follow this and additional works at: https://digitalcommons.mtu.edu/etds

Part of the Civil and Environmental Engineering Commons

Copyright 2010 Ryu Suzuki

\section{Recommended Citation}

Suzuki, Ryu, "Post-project assessment and follow-up support for community managed rural water systems in Panama ", Master's report, Michigan Technological University, 2010.

https://doi.org/10.37099/mtu.dc.etds/515

Follow this and additional works at: https://digitalcommons.mtu.edu/etds

Part of the Civil and Environmental Engineering Commons 


\title{
POST-PROJ ECT ASSESSMENT AND FOLLOW-UP SUPPORT FOR COMMUNITY MANAGED RURAL WATER SYSTEMS IN PANAMA
}

By

Ryu Suzuki

\author{
A REPORT \\ Submitted in partial fulfillment of the requirements for the degree of \\ MASTER OF SCIENCE \\ ENVIRONMENTAL ENGINEERING \\ MICHIGAN TECHNOLOGICAL UNIVERSTIY \\ 2010
}


This report, "Post-Project Assessment and Follow-Up Support for Community Managed Rural Water Systems in Panama" is hereby approved in partial fulfillment of the requirements for the degree of MASTER OF SICENCE IN ENVIRONMENTAL ENGINEERING.

Civil and Environmental Engineering

Master's International Program

Signatures:

Report Adviser

Dr. J ames R. Mihelcic

Department Chair

Dr. William Bulleit

Date 


\section{Table of Contents}

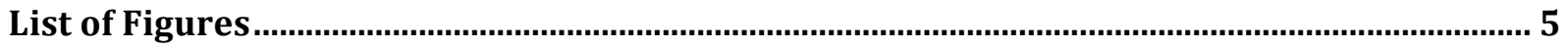

List of Tables

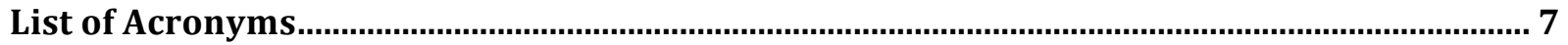

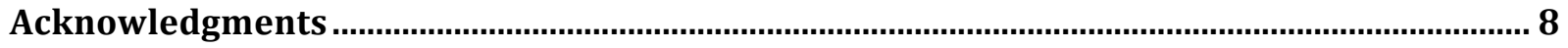

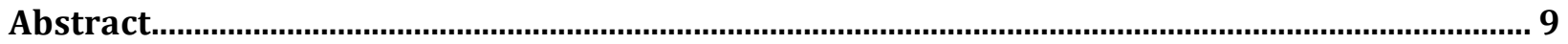

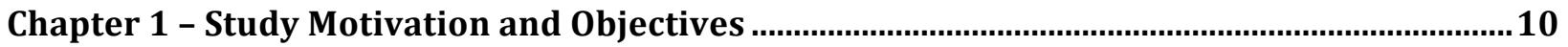

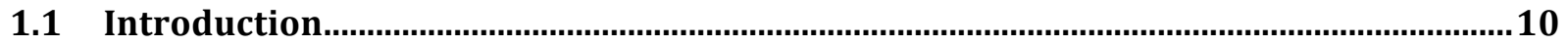

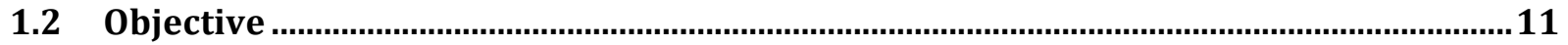

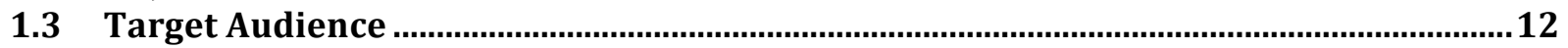

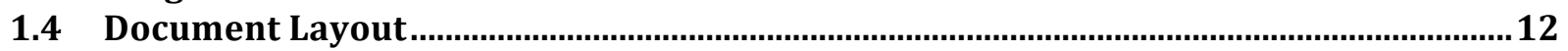

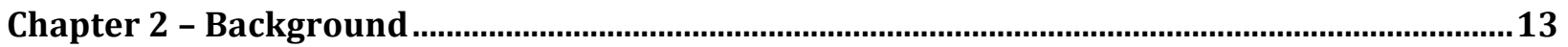

2.1 Community Management Model and its Limits .................................................................. 13

2.2 Evaluation and Monitoring of Rural Water Systems.......................................................15

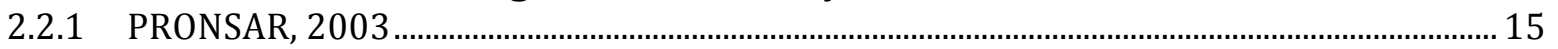

2.2.2 Methodology for Participatory Assessment, 2003 …............................................................ 17

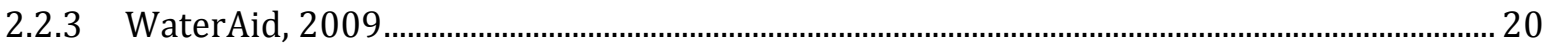

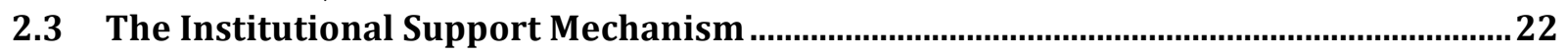

2.3.1 Technician in Operation and Maintenance Program in Honduras, 2001 ........................... 23

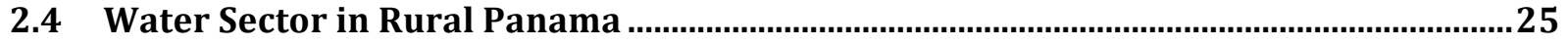

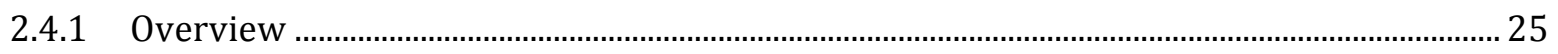

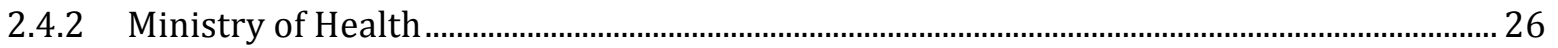

2.4.3 Community Managed Rural Water Systems in Panama ............................................................ 26

2.5 Peace Corps Panama - Environmental Health Program...................................................2

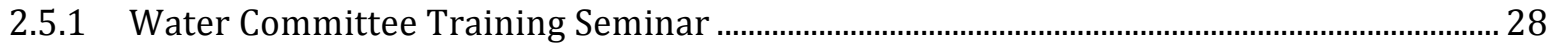

2.5.2 The Environmental Health Program Niche .............................................................................. 28

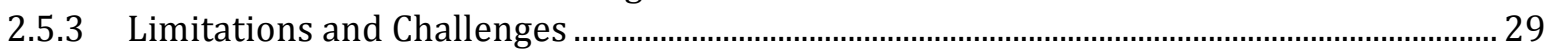

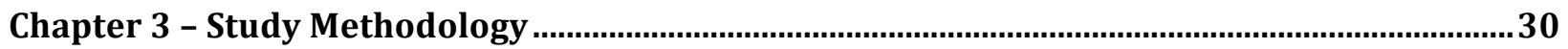

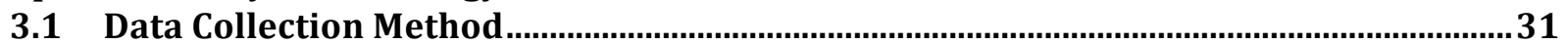

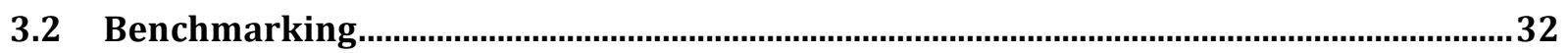

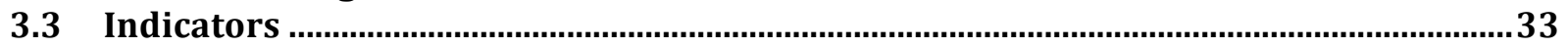

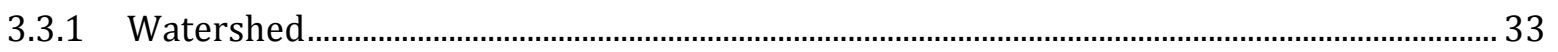

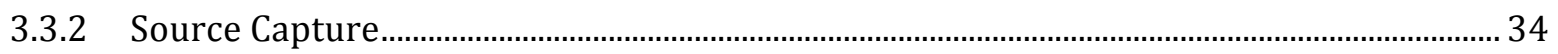

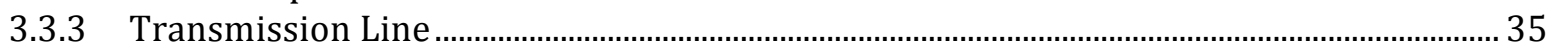

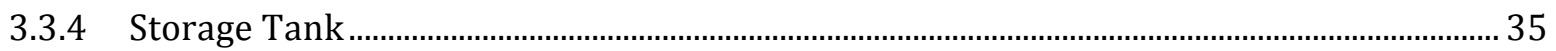

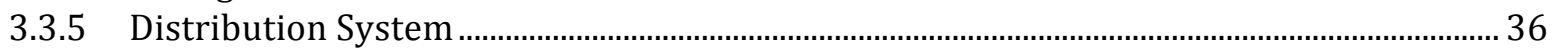

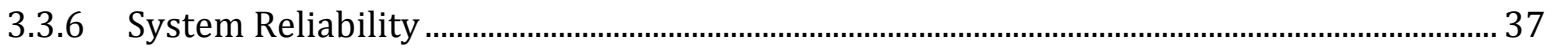

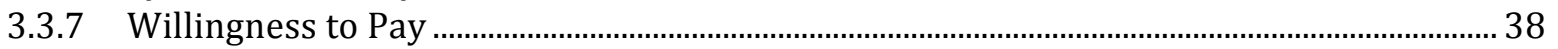

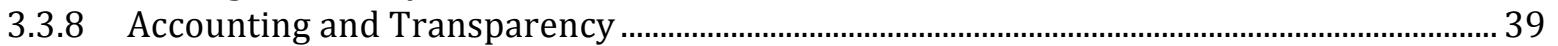

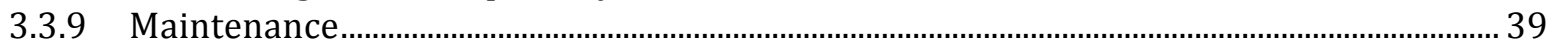

3.3.10 Number of Active Committee Members .............................................................................. 39

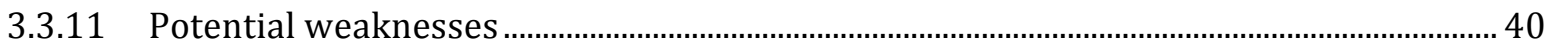

Chapter 4 - Post-Project Assessment of 28 Rural Water Systems ..............................................41

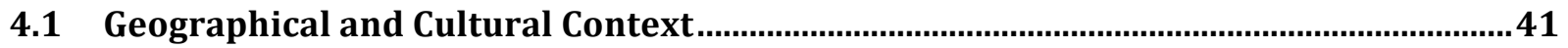

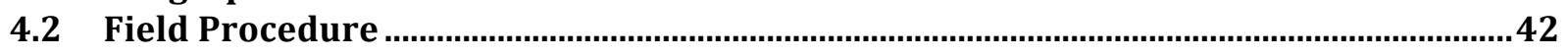

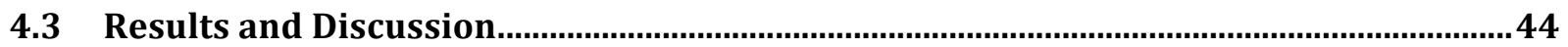




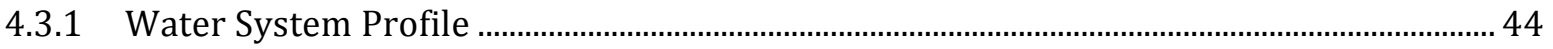

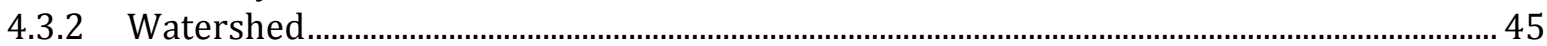

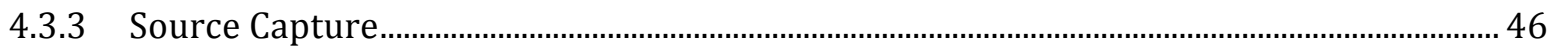

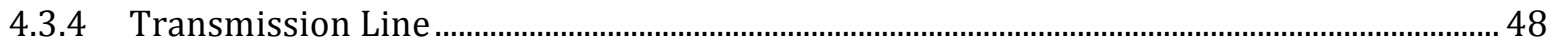

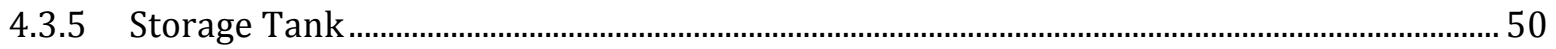

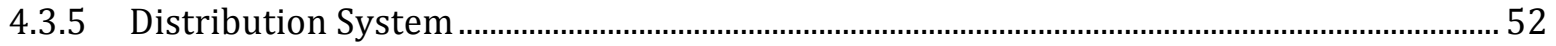

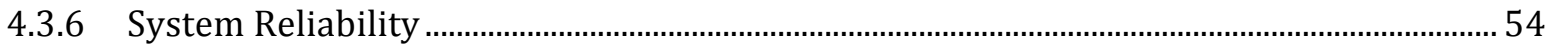

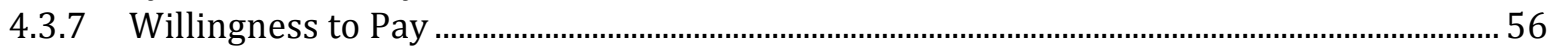

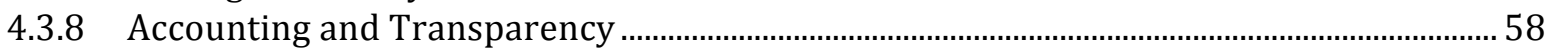

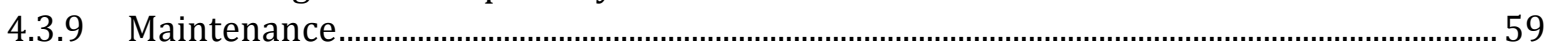

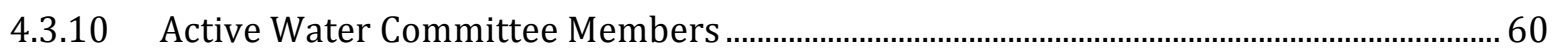

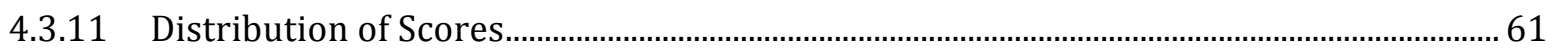

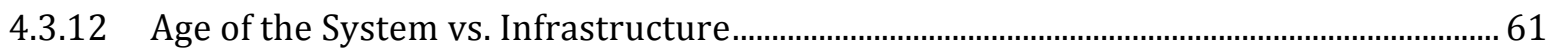

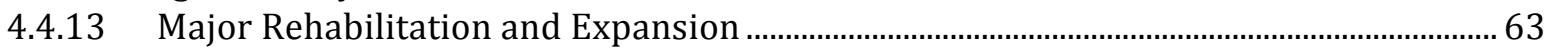

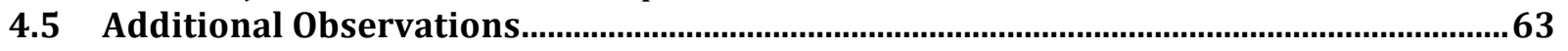

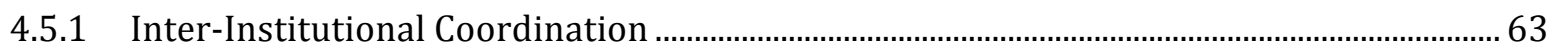

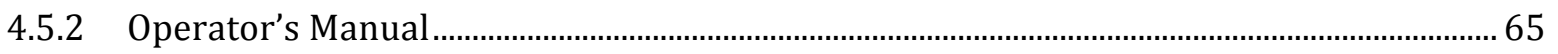

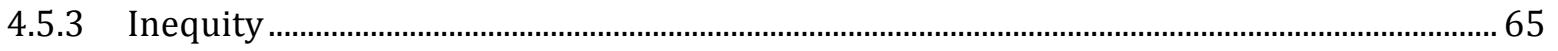

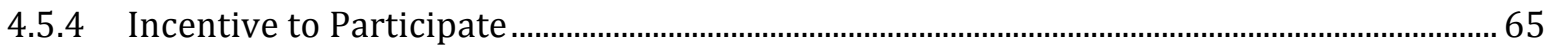

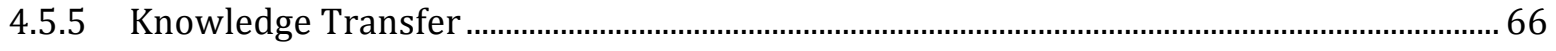

4.6 Request for Follow-Up Support

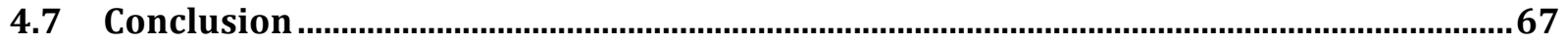

Chapter 5 - Incorporating Institutional Support Mechanism into the Environmental Health

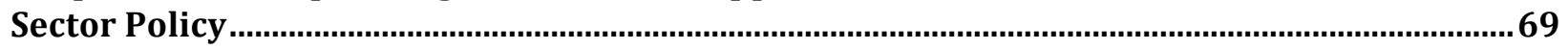

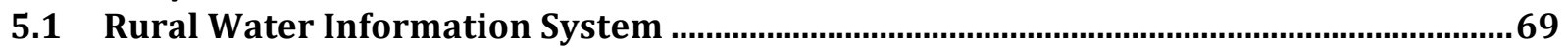

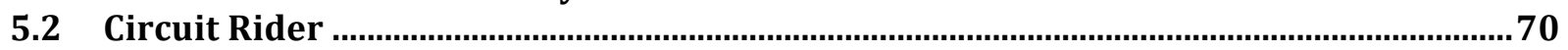

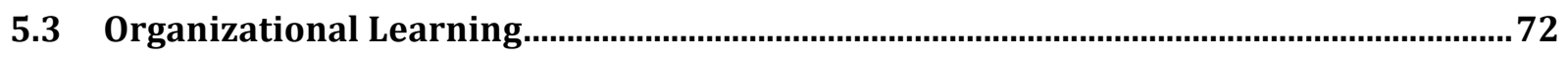

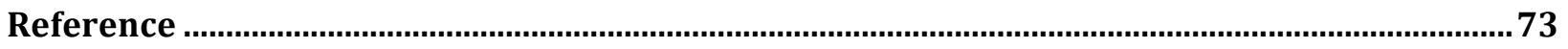

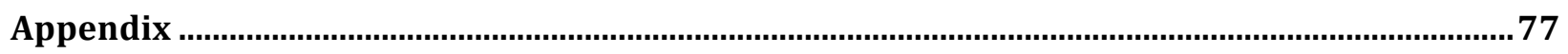

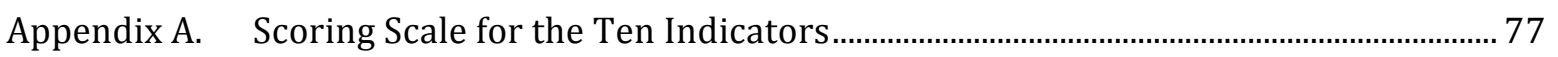

Appendix B. Scoring Scale for the Ten Indicators in Spanish ......................................................... 78

Appendix C. Scores Given to Each Community ……….................................................................... 79

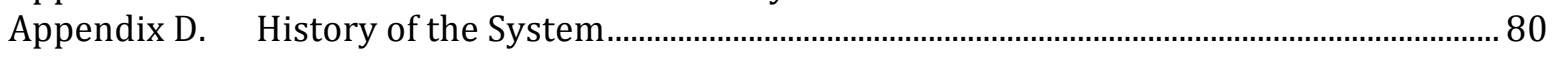

Appendix E. Summary of Community Visits........................................................................................ 82

Appendix F. Recommended Follow-Up for Each Community ……................................................ 85

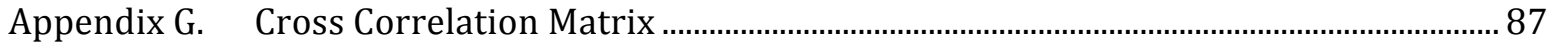




\section{List of Figures}

Figure 1. Three components of Sustainability Snapshot and Separation of Roles...................21

Figure 2. $\quad$ Map of 28 water systems marked with a yellow pin (Google Earth, 2010)...............41

Figure 3. Results for the watershed indicator. ................................................................. 45

Figure 4. Photos of the watershed. (a) - Example of a well-protected watershed taken in Bahia

Azul, Comarca Ngäbe-Buglé (CNB) Nukribo. (b) - Land surrounding the source has been

cleared off for agriculture use in Cerro Puerco, CNB Kadri region..................................... 46

Figure 5. Results from the source catchment indicator. .......................................................4 46

Figure 6. Spring boxes with major water loss. (a) - Photo taken in Tobobe, CNB Nukribo. (b)

- Photo taken in Oriente de Risco, Bocas del Toro............................................................. 47

Figure 7 Two types of spring boxes. (a) - Traditional design with a taller collection box (photo taken in San Pedro, Cocle). (b) - Nicolas Arcia's original design with much lower placement of outlet and overflow pipes..

Figure 8. Results for the transmission line. ................................................................. 48

Figure 9. Common problems with the transmission line. (a) - Tube exposed by erosion in

Cerro Puerco, CNB Kadri. (b) - Tubes that were never buried in Punta Valiente, CNB

Ñukribo. (c) - Hole covered for air release covered with a piece of wooden stick in Salto Dupi, CNB Nedrini. (d) - Homemade air release valves that was found to be leaking in

Cerro Puerco, CNB Kadri.

Figure 10. Problems with poor repair job of transmission lines. (a) - Rocks used to weigh down poorly made joints in Salto Dupi, CNB Nedrini. (b) - J oints fabricated over direct fire and connected without any PVC glue in Playa Balsa, CNB Ñukribo........................... 50

Figure 11. Results for storage tank assessment. ................................................................ 50

Figure 12. Common problems with storage tanks. (a) - Corners of the storage tank leaking in

Cayo Paloma, CNB Ñukribo. Outlet pipe connection leaking in Cayo Paloma, CNB

Nukribo.

Figure 13. Results for the distribution system............................................................... 52

Figure 14. Tap stand lowered to the ground level due to lack of pressure (Photo taken in

Oriente de Risco, Bocas del Toro)...................................................................................... 52

Figure 15. Results for the system reliability............................................................... 54

Figure 16. Linear regression analysis between the infrastructure and system reliability......... 55

Figure 17. Results for the willingness to pay. ........................................................................ 56

Figure 18. Ledger used to keep track of monthly payments in J unquito, Bocas del Toro. ....... 56

Figure 19. Results for accounting and transparency......................................................... 58

Figure 20. Examples of good accounting practices. (a) - Proof of payment for monthly tariffs

handed out to users in Nudobidy, Bocas del Toro. (b) - Receipts are well organized in

Nudobidy, Bocas del Toro. (c) - The official JAAR balance sheet that was provided by

MINSA (Punta Valiente, CNB Ñukribo)....................................................................... 59

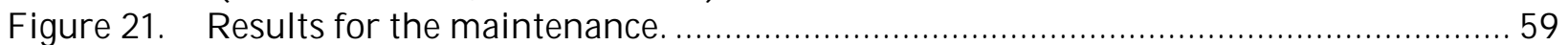

Figure 22. Results for the active water committee members...............................................6 60

Figure 23. Age of the system (years) vs. infrastructure score ...............................................6. 62

Figure 24. 5,000-gallon tank constructed by a PCV and 10,000-gallon tank constructed by

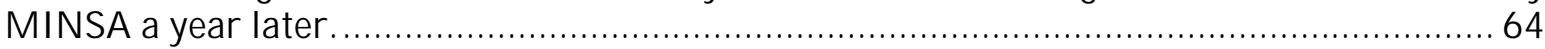




\section{List of Tables}

Table 1. PRONSAR's water system classification. ............................................................. 16

Table 2. Advantages and disadvantages of participatory analysis. .....................................19

Table 3. An example of benchmarking utilized in the Methodology in Participatory

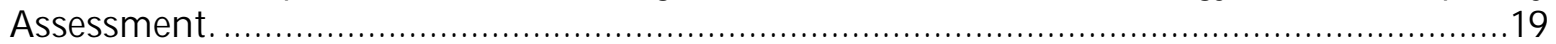

Table 5. An example of ranking system from Sustainability Snapshot.................................21

Table 6. Water System Classification and Remedial Action. .................................................. 24

Table 7. Definition of sustainability according to each methodology................................. 30

Table 8. Ten indicators measured in the methodology....................................................... 33

Table 9. Scoring Scale for Watersheds. Contaminants can be derived from the following sources: open defecation or latrines, animals, agrochemicals......................................... 34

Table 10. Scoring Scale for Source Protection and Catchment. ............................................ 35

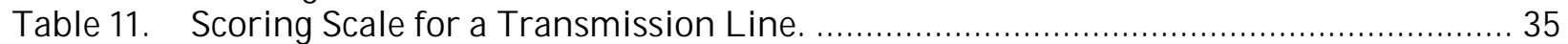

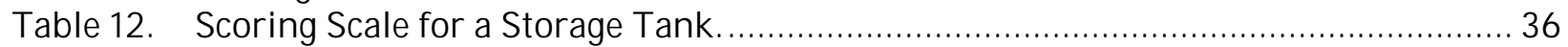

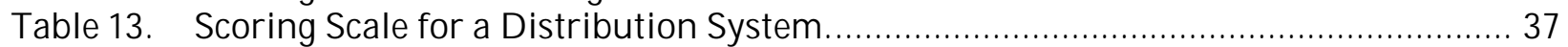

Table 14. Scoring Scale for System Reliability..................................................................... 38

Table 15. Scoring Scale for Willingness to Pay. The percentage is derived from dividing total number of monthly tariffs collected in a given year by total number of monthly tariffs that should be collected in year based on the number of houses. ........................................... 38

Table 16. Scoring Scale for Accounting and Transparency. ................................................... 39

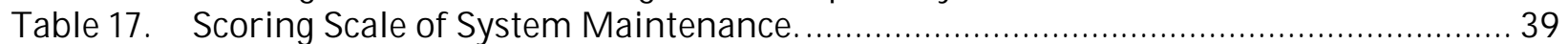

Table 18. Scoring Scale for Number of Active Water Committee Members.............................4 40

Table 19. Distribution of scores for the ten indicators (\%). ..................................................61

Table 20. Age of water systems built by PCV and its corresponding infrastructure score........ 62 


\section{List of Acronyms}

\begin{tabular}{|c|c|}
\hline ANAM & Autoridad Nacional del Ambiente (National Environmental Authority) \\
\hline AHA & Asset Holding Authority \\
\hline $\mathrm{CNB}$ & Comarca Ngäbe-Buglé \\
\hline COWSO & Community-Owned Water Supply Organizations \\
\hline $\mathrm{CM}$ & Community Management \\
\hline $\mathrm{EH}$ & Environmental Health \\
\hline FGD & Focus Group Discussion \\
\hline IRC & International Water and Sanitation Centre \\
\hline ISM & Institutional Support Mechanism \\
\hline \multirow[t]{2}{*}{ JAAR } & J unta Administradoras de Acueductos Rurales (Rural Water System \\
\hline & Administrator Council) \\
\hline MDG & Millennium Development Goal \\
\hline MINSA & Ministerio de Salud (Ministry of Health) \\
\hline MPA & Methodology for Participatory Assessment \\
\hline NGO & Non-Governmental Organization \\
\hline NRWA & National Rural Water Association \\
\hline O\&M & Operation and Maintenance \\
\hline $\mathrm{PC}$ & Peace Corps \\
\hline PCV & Peace Corps Volunteer \\
\hline \multirow[t]{2}{*}{ PRONSAR } & Proyecto Programa Nacional de Agua y Saneamiento Rural (National Rural \\
\hline & Water and Sanitation Program) \\
\hline RWS & Rural Water System \\
\hline \multirow[t]{2}{*}{ SANAA } & Servicio Autónomo Nacional de Acueductos y Alcantarillados (National Water \\
\hline & Supply and Sewage Company) \\
\hline \multirow[t]{2}{*}{ SIAR } & Sistema de Información de Acueductos Rurales (Rural Water Information \\
\hline & System) \\
\hline $\mathrm{SDC}$ & Swedish Agency for Development \\
\hline \multirow[t]{2}{*}{ TOM } & Técnico en Operación y Mantenimiento (Technician in Operation and \\
\hline & Maintenance) \\
\hline UNICEF & United Nations Children's Fund \\
\hline WHO & World Health Organization \\
\hline WSP & World Bank Water and Sanitation Program \\
\hline
\end{tabular}




\section{Acknowledgments}

I would first like to thank James Mihelcic, Dave Watkins and Blair Orr for serving on my defense committee and guiding me with valuable feedback and advice throughout my time as a Master's candidate.

Thank you to the following Peace Corps Panama staff for providing me with professional and personal support during my three and a half year service as a volunteer: Brian Riley, J en Albee, Zach Barricklow, Raul Ramirez, Lisa Andrusyszyn, Juan Perez, Brandon Valentine, Carlos Moreno, Franklin Cano and Tess de Dos Rios. Huge thanks to my APCD Tim Wellman for presenting me with the opportunity to carry out this study and always encouraging me to professionalize my service. Thanks to Waterlines for accepting this study proposal and providing financial support to cover my travel expenses.

I appreciate all the following volunteers and friends that allowed me to stay in their homes as I travelled across the country to visit water systems: Ricardo Carpintero, Victoria Flagg, Drew Lebowitz, Carey Mandel, Michael Stauthammer, Mateo Johnson, Stephanie Westman, Jim Fraser, Jamie Konecney, Audrey Blocker, Joanna Seliga, Kat Fraser, Erin Kelley, Aleah Sommers and Andy Newman.

To my family, who have always blessed me with their unconditional love and support no matter what path I chose to take. To my good friend Ryan Schweitzer, the work he has completed in this field served as a great guideline to complete my study.

Finally, I would like to thank all those hard-working members of the water committees in rural Panama. I would not have been able to inspect the water systems if they had not agreed to take me across what is often a treacherous trail to the water source. Their dedication to the common good is what keeps the water flowing in their communities. I could only hope that the fruits of this report will help them ensure the longevity of their water systems. 


\section{Abstract}

The Environmental Health (EH) program of Peace Corps (PC) Panama and a non-governmental organization (NGO) Waterlines have been assisting rural communities in Panama gain access to improved water sources through the practice of community management (CM) model and participatory development. Unfortunately, there is little information available on how a water system is functioning once the construction is complete and the volunteer leaves the community. This is a concern when the recent literature suggests that most communities are not able to indefinitely maintain a rural water system (RWS) without some form of external assistance (Sara and Katz, 1997; Newman et al, 2002; Lockwood, 2002, 2003, 2004; IRC, 2003; Schweitzer, 2009).

Recognizing this concern, the EH program director encouraged the author to complete a postproject assessment of the past EH water projects. In order to carry out the investigation, an easy to use monitoring and evaluation tool was developed based on literature review and the author's three years of field experience in rural Panama. The study methodology consists of benchmark scoring systems to rate the following ten indicators: watershed, source capture, transmission line, storage tank, distribution system, system reliability, willingness to pay, accounting/transparency, maintenance, and active water committee members.

The assessment of 28 communities across the country revealed that the current state of physical infrastructure, as well as the financial, managerial and technical capabilities of water committees varied significantly depending on the community. While some communities are enjoying continued service and their water committee completing all of its responsibilities, others have seen their water systems fall apart and be abandoned. Overall, the higher scores were more prevalent for all ten indicators. However, even the communities with the highest scores requested some form of additional assistance.

The conclusion from the assessment suggests that the EH program should incorporate an institutional support mechanism (ISM) to its sector policy in order to systematically provide follow-up support to rural communities in Panama. A full-time circuit rider with flexible funding would be able to provide additional technical support, training and encouragement to those communities in need. 


\section{Chapter 1 - Study Motivation and Objectives}

\subsection{Introduction}

The most recent study estimates that $87 \%$ of the world population has access to an improved water source (WHO/UNICEF, 2010). This is a 10\% improvement (or 1.8 billion additional people) compared to the 1990 level. At the current rate, the world is on track to exceed the target set by the seventh Millennium Development Goal (MDG) of halving the population without access to improved water source by year 2015. Even strong critics of the foreign aid industry suggest that advancements made in water and sanitation sector is one of the few success stories of development organizations (Easterly, 2006).

The figures mentioned in the previous paragraph do not however count for the disparity between urban and rural areas. Urban areas tend to have better access to improved water sources, as $84 \%$ of the world population without access lives in rural areas (WHO/UNICEF, 2010). The rural population without access to improved water is five times greater than the urban area. Although the need is much greater in rural areas, the percentage of the rural population with access to improved water source still increased from 64\% in 1990 to $78 \%$ in 2008.

Investment in a piped connection is most responsible for progress in access to an improved water source (WHO/UNICEF, 2010). Between 1990 and 2008, 1.2 billion people worldwide gained access to a piped connection. In Latin America, 167 million additional people now have a piped connection near their household. In rural areas, given the proper topography, a gravityfed water distribution system has been the preferred choice for piped systems. Compared to pumped systems, the lack of mechanical parts and complex machinery make construction, operation and maintenance easier and more affordable.

However, the long-term sustainability of these water systems, especially in rural areas, has always been a concern for many actors working in the area of water supply. Despite the continued investment made by government agencies and international organizations in the construction of infrastructure, most of these communities will inevitably face many problems after a few years of operation. In fact, it is now recognized that there is a limit to how long a 
community can sustain a water system without any form of external assistance (Sara and Katz, 1997; Newman et al, 2002; Lockwood, 2002, 2003, 2004; IRC, 2003; Annis, 2006).

\subsection{Objective}

The Environmental Health (EH) sector of Peace Corps (PC) Panama and a non-governmental organization (NGO) Waterlines have been assisting rural communities in Panama to gain access to improved water sources. Peace Corps Volunteers (PCVs) receive training on how to use concepts from the community management (CM) model and participatory development to complete water projects. Community involvement and capacity building are emphasized throughout the project life cycle to ensure that communities possess the sense of ownership and ability to maintain the water system. The EH sector and Waterlines have made some contribution to the fact that WHO/UNICEF's (2010) estimate on the percentage of rural population in Panama with access to improved water source increased from 66\% in 1990 to 83\% in 2008.

Unfortunately, there is very little information available on how a water system is functioning once the construction is complete and the volunteer leaves the community. This is concerning, given that other research in Latin America indicates that 20 to $50 \%$ of rural water systems (RWS) do not function as originally designed (PRONSAR, 2003; BNWP, 2009). Even if the volunteer was able to successfully implement the best practices in the CM model, the recent literature (Sara and Katz, 1997; Newman et al, 2002; Lockwood, 2002, 2003, 2004; IRC, 2003; Schweitzer, 2009) suggests that most communities are not able to indefinitely maintain a RWS without any form of external assistance. Accordingly, the purpose of this research is to:

1. Establish an easy to use tool to monitor and evaluate gravity-fed water distribution systems and water committees in rural communities in Panama.

2. Present results from the post-project assessment of 28 RWS built or rehabilitated by PCVs with funding from the NGO Waterlines.

3. Discuss how the EH sector could incorporate Institutional Support Mechanism (ISM) to their sector policy in order to systematically provide follow-up support for past water projects. 


\subsection{Target Audience}

This report aims to provide pragmatic guidelines for the EH sector and NGO Waterlines in providing better services to the rural communities. The Peace Corps EH program director Tim Wellman was the first to recognize the need to complete a study of past water projects implemented by PCVs. Information on the current state of water systems would help strategize how to effectively provide follow-up support to communities in need and ensure longevity of these water systems. This report could also serve as an additional resource for governments, NGOs, and development workers interested in monitoring and evaluation of RWS and follow-up support for past projects.

\subsection{Document Layout}

The remainder of this document consists of four main sections.

Chapter 2 presents relevant literature regarding the limitations of the CM model, different methodologies for evaluation of RWS, and implementation of ISM. It also introduces readers to the overview of the rural water supply sector in Panama.

Chapter 3 introduces the methodology established to assess the physical state of infrastructure as well the financial, managerial, and technical capabilities of water committees. This methodology, developed based on a literature review and the author's three-year experience in rural Panama, relies mainly on direct observation and informal interviews to collect data.

Chapter 4 presents the results from the assessment of 28 water systems built or rehabilitated by $\mathrm{EH}$ volunteers. The study found that the state of water systems and water committees varied depending on the community.

Chapter 5 discusses how EH could incorporate ISM into the sector plan in order to provide additional help to ailing water systems and water committees. 


\section{Chapter 2 - Background}

\subsection{Community Management Model and its Limits}

The community management (CM) model has been gaining popularity as one of the best practices for managing rural water supply projects since the 1980s (Narayan, 1993; Brikke, 2000). Rather than treating community members as passive beneficiaries, they are encouraged to become active participants by playing a greater role in the decision-making process and project management. The capacity of community members to manage, operate and maintain water projects on their own thus becomes just as important as the quality of construction. Today, the CM model is the preferred option for four main stakeholders in the development field with different agendas and priorities (Orr and Annis, 2009). These stakeholders are governments, NGOs, private donors, and multinational lenders.

CM of rural water systems (RWS) usually implies existence of water committees or water boards at the community level. Water committees typically consist of several members of the community that are democratically elected by the beneficiaries. Depending on the country or region, some water committees may have a legal status officially recognized by the government while others are informal. Below are some common roles of a water committee (Bolt and Fresca, 2001 referenced by Orr and Annis, 2009):

- Structure community decisions around system management.

- Organize contributions and control finances.

- Inform the community.

- Act as a liaison when dealing with water users.

- Ensure proper operation of the water system.

- Oversee technicians; coordinate maintenance and replacement of parts.

Researchers over the years have found that participatory projects such as the CM model tend to be more sustainable than a top-down approach (Mansuri and Rao, 2003). A growing body of evidence suggests that the sustainability of water systems is highly correlated with the level of community participation in project planning, implementation, and management, and adequate training for water committees and individual households (Narayan, 1993; Sara and Katz, 1997; PRONSAR, 2003). 
The CM model also has been subject to many criticisms since its introduction in the development field. Successful implementation of the CM model requires "slow, gradual, persistent learning-by doing, where project design gradually adapts to local conditions by learning from the false starts and mistakes that are endemic to all complex interventions" (Mansuri and Rao, 2003). This means that dedicated development practitioners with the right personal traits (cultural respect, humbleness, patience, flexibility, excellent communication ability in native tongue, etc.), and sufficient training and experience in participatory methods would have to spend considerable amount of time at each community (Sara and Katz, 1997; Mukherjee and van Wijk, 2003). Recruiting, training and financially supporting all of these individuals pose great logistical and financial burdens for many organizations (Feachem, 1980).

Even the most qualified and experienced professionals could not guarantee successful community-based development projects. Not all communities have competent members who are willing and able to dedicate their services and time to voluntarily participate in such projects (White, 1981; Hayward, Simpson, and Wood, 2004). There are also communities divided by personal, political or ethnical differences, where the CM model might not be the best option.

Regarding sustainability of RWS, Lockwood (2004) identified internal and external factors that cause problems in the CM model:

- Limitations within the community: community dynamics, political or social conflict, failure to generate sufficient tariff revenue, lack of preventative maintenance, lack of cohesion and lack of capacity (technical, managerial, financial, etc).

- Constraints external to the community: poor designs, poor implementation, political interference in planning and resource allocation, lack of spare parts supply, lack of supportive policies and legislation and, very importantly, the lack of long-term support to help communities through major repairs, conflicts and other problems with extension and upgrading.

Although participatory processes and training could have significant impact on the sustainability of water systems, it is unrealistic to assume that rural communities are able to solve all the problems mentioned above on their own. Traditionally, the local governmental institutions had the responsibility of providing this extra support (Lockwood, 2002). However, most institutions lack the capital and human resources as well as clearly identified procedures and mechanisms to effectively serve numerous and disperse rural communities. International 
donors continuing to invest in construction of new water systems have exacerbated this problem. Increased coverage has forced already over-stretched local agencies to take on additional responsibilities. Although historically most donor agencies have failed to make a substantial investment in the post-construction phase, this situation is slowly changing.

\subsection{Evaluation and Monitoring of Rural Water Systems}

Growing concern for the limitations of the community management (CM) model and long-term sustainability of rural water systems have motivated various researchers and organizations to develop evaluation and monitoring tools for RWS and return to communities where water systems have been constructed to test them. Following is a review of three methodologies developed and implemented to assess the sustainability of RWS. These methodologies vary depending on how each researcher or organization defines scope and goals of their study as well as the meaning of sustainability.

\subsubsection{PRONSAR, 2003}

The Peruvian National Rural Water and Sanitation Program (PRONSAR), Swedish Agency for Development and Cooperation (SDC), and the World Bank Water and Sanitation Program (WSP) collaborated to complete a study of 104 rural communities in Peru with water systems that were more than three years old (PRONSAR, 2003). Six different local NGOs also helped to collect the data for this study. The investigators used the aggregate scoring system to rank each water system into one of the following categories as shown in Table 1. 


\begin{tabular}{|l|c|l|}
\hline \multicolumn{1}{|c|}{ Category } & Score & \multicolumn{1}{c|}{ Description } \\
\hline $\begin{array}{l}\text { Sustainable } \\
\text { service }\end{array}$ & $75-100 \%$ & $\begin{array}{l}\text { The infrastructure is in optimal condition continuously providing } \\
\text { excellent quantity and quality of water. The water committee is able } \\
\text { to administer the system effectively and has equal representation of } \\
\text { men and women. The beneficiaries are satisfied with the system and } \\
\text { cooperate with the maintenance work. }\end{array}$ \\
\hline $\begin{array}{l}\text { System in } \\
\text { process of } \\
\text { deterioration }\end{array}$ & $50-75 \%$ & $\begin{array}{l}\text { The infrastructure is slowly deteriorating as it suffers from occasional } \\
\text { intermittent service and the quality of water is not at an optimal level. } \\
\text { There are some problems with the administration of the system, } \\
\text { collection of tariffs, and inadequate maintenance and operation. } \\
\text { However, the deficiency could be improved with some training for } \\
\text { the water committee and users, and minor reparations for the } \\
\text { infrastructure. }\end{array}$ \\
\hline $\begin{array}{l}\text { System in } \\
\text { process of } \\
\text { severe } \\
\text { deterioration }\end{array}$ & $25-50 \%$ & $\begin{array}{l}\text { The water committee is completely disorganized and very little } \\
\text { community participation is observed. There is a major deficiency in } \\
\text { the infrastructure. For the system to function properly, it would } \\
\text { require major investment in the rehabilitation of the infrastructure as } \\
\text { well as extensive training programs for the water committee and } \\
\text { community members. }\end{array}$ \\
\hline $\begin{array}{l}\text { Collapsed } \\
\text { system }\end{array}$ & $0-25 \%$ & \begin{tabular}{l} 
The system provides no service and has been abandoned. \\
\hline
\end{tabular}
\end{tabular}

Table 1. PRONSAR's water system classification.

Each investigation team consisted of a social and a technical expert. The field procedure started with a meeting with the entire community to explain the purpose and methodologies of the study. The technical expert assessed the state of infrastructure through direct observation during transect-walks with water committee members and other leaders. The social expert assessed the administrative capacity and community participation using informal conversations with water committees and leaders, and a general meeting with the entire community. The results were presented verbally to the community with a promise to send a written report later.

To assess the state of infrastructure, the technical experts observed the following components: the source catchment, conduction line, treatment system, reservoir, distribution network, public taps, and domestic taps. Each component was ranked as good, normal or bad/non-operational. The investigators also examined the quality of water, percentage of population with service, and continuity of service. The scores given to each component were compiled into a general score for the state of the system.

To assess the administrative capacity and level of community participation, the social expert asked a series of key questions regarding operation and maintenance, collection of tariffs, user 
satisfaction, extent of training received, and level of participation of women. A score was given for each indicator based on how the community members responded to the questions. Once again, these scores were compiled to estimate the capacity of the community to maintain the system.

The study completed in 104 communities produced the following results:

- According to their ranking system, $31.7 \%$ of systems were sustainable, $44.3 \%$ were in process of deterioration, $22.1 \%$ were in process of severe deterioration, and $1.9 \%$ had collapsed completely.

- Delegating construction to community members led to installing a sense of ownership. However, a sense of ownership is not enough to guarantee system sustainability.

- The lack of administrative capacity is most responsible for system deterioration. The institutions must provide follow-up support for multiple years even after the completion of construction.

- Many water committees and operators did not receive sufficient training.

- Better design and construction supervision is necessary to ensure the quality of infrastructure.

- There are communities with sustainable water systems and excellent financial management, which provide a model and standard of how communities should manage their water service.

- The weakness or lack of health education is limiting the health benefits of water projects.

- Women that attended community meetings were either single or sent by their husbands who could not attend the meeting. Even when women attended the meetings, they did not feel comfortable to express their opinions.

\subsubsection{Methodology for Participatory Assessment, 2003}

A joint team from the World Bank Water and Sanitation Program (WSP) and International Water and Sanitation Centre (IRC) from Holland developed this methodology to conduct a major study involving 88 communities from 15 countries (Mukherji and van Wijk, 2003). The principlal framework of the Methodology for Participatory Assessment (MPA) is based on a hypothesis that "communities sustain their service when projects are more participatory, demand-responsive1, gender and poverty-sensitive" (Gross et al, 2002). The investigators

\footnotetext{
${ }^{1}$ Demand-responsive refers to a degree to which the project is initiated based on priorities of each individual household rather than by priorities of village leaders or outside organizations (Katz and Sara, 1997).
} 
believed that equitable participation between men and women, and poor and rich within the community in water system management is highly correlated with its sustainability.

A complete team of investigators trained and well-experienced in facilitating participatory activities stayed in each community for five days. Each team consisted of at least one water and sanitation engineer, one anthropologist, both genders, and somebody from the same ethnic and cultural background of the communities being studied. They carried out various participatory activities such as focus group discussions, social mapping, pocket voting, transect-walks and Venn-diagram with different social and gender groups of each community. All these assessment tools use open-ended and visual methods to make local situations and practices visible. They also do not require literacy or high education level, permitting everybody to participate.

The MPA was designed by taking into account the advantages and disadvantages of using participatory analysis as a monitoring and evaluation tool as summarized in Table 2. The main characteristic is that it quantifies qualitative data collected through participatory processes with community members and agency staff. This allows researchers and managers to perform statistical analysis at the program level, while the community members and agency staff act out based on what they learned together from the participatory activities. 


\begin{tabular}{|c|c|}
\hline Advantages & Disadvantage \\
\hline $\begin{array}{l}\text { - Enable quick visual representation of local } \\
\text { conditions and practices, minimizing } \\
\text { biases resulting from spoken languages. } \\
\text { - Any person can participate irrespective of } \\
\text { their levels of literacy or education. } \\
\text { - Participants are free to present their own } \\
\text { views, knowledge, and interests on each } \\
\text { subject. Larger sections of population are } \\
\text { able to express their views. Rich, } \\
\text { insightful information is obtained. } \\
\text { - For the subordinated, self-expression with } \\
\text { tools is easier than public speaking. } \\
\text { - The process is not limited or influenced by } \\
\text { questions from outsiders, minimizing } \\
\text { interviewer biases encountered in } \\
\text { conventional surveys. } \\
\text { - The public process makes it hard to present } \\
\text { and retain faulty information. } \\
\text { - Systematic overviews act as eye-openers } \\
\text { regarding previously unnoticed problems. } \\
\text { - Outcomes are immediately shared, open to } \\
\text { analysis and conclusions by all. } \\
\text { - People remain owners of the knowledge } \\
\text { and can immediately act upon it. }\end{array}$ & $\begin{array}{l}\text { - Qualitative data is not suitable for } \\
\text { aggregation, statistical analysis and for } \\
\text { building up a program database over time. } \\
\text { - Comparability between and across } \\
\text { communities on results and common factors } \\
\text { is limited as indicators and/or ways of } \\
\text { investigation often differ. } \\
\text { - Participatory methods have a reputation of } \\
\text { being slower and more costly than social } \\
\text { surveys. } \\
\text { - Prevailing perceptions from some managers } \\
\text { that there may not be anything worth } \\
\text { learning from the views of poor people. }\end{array}$ \\
\hline
\end{tabular}

Table 2. Advantages and disadvantages of participatory analysis.

The qualitative data is converted into quantitative data by using the ordinal scale or benchmarks. Each indicator is assigned with descriptive categories arranged in graduated orders with corresponding score scale. The score of " 4 " represents the ideal situation and " 0 " represents the least ideal. Through various participatory activities, different focus groups within each community will rank themselves regarding each indicator. Table 3 is an example of an ordinal scale used to quantify the situation regarding financing for operation and maintenance (O\&M).

\begin{tabular}{|c|l|}
\hline $\begin{array}{c}\text { Score given by } \\
\text { community }\end{array}$ & \multicolumn{1}{|c|}{$\begin{array}{c}\text { Description of scoring for financing of operation and } \\
\text { maintenance }\end{array}$} \\
\hline $\mathbf{0}$ & No user payments \\
\hline $\mathbf{1}$ & Payments made but do not cover annual O\&M cost \\
\hline $\mathbf{2}$ & Payments just enough to cover annual O\&M cost \\
\hline $\mathbf{3}$ & Payments cover all annual O\&M costs and repairs \\
\hline $\mathbf{4}$ & $\begin{array}{l}\text { Payments generate annual surpluses, over and above annual O\&M } \\
\text { cost and repair (for future expansion/replacement of system) }\end{array}$ \\
\hline
\end{tabular}

Table 3. An example of benchmarking utilized in the Methodology in Participatory Assessment. 
Based on the evaluation of 88 communities from 15 different countries, the investigators identified that sustainability is strongly correlated with five factors:

- Effective use as described by the extent of community members using the water systems in a way to promote health.

- Better gender and poverty focus during operation.

- The degree of demand-responsiveness in project implementation.

- The level of participation leading to empowerment.

- The level of user satisfaction-rate.

\subsubsection{WaterAid, 2009}

WaterAid, a NGO based in the United Kingdom, completed a study of 30 community-owned water supply organizations (COWSO) from 10 provinces in Tanzania (Nkong, 2009). The goal of the study was to gain a better understanding of relationships between sustainability and internal regulations regarding water systems. More specifically, it aimed to test two hypotheses that; 1) separation of roles and powers are necessary for sustainability, and 2) greater participation and better regulations regarding system management are key factors in sustainability. Separation of roles refers to a degree that the roles and responsibilities regarding system management were defined and community members held each other accountable for completing them.

This research was mostly qualitative using semi-structured interviews, focus group discussions (FGD) and direct observation. The investigators held discussions with four separate focus groups within each community: male users, female users, management committees and village governments. For each FGD session, the respective tools "Sustainability Snapshot" and "Separation of Roles" were utilized to gauge community perception concerning the sustainability of their water system and the degree to which the roles of people using and managing the system were defined and regulated.

Sustainability Snapshot and Separation of Roles are tools for rapid assessment developed to be easy to use and understand, applicable to all situations, non-prescriptive and discussion provoking. Each tool consists of three critical factors that are considered to be most important for the sustainability of water systems. The lists of critical factors are demonstrated in Figure 1. 
Community perception with regards to sustainability (Sustainability Snap Shot)

- Finance: if the community has enough funds to carry out repairs and/or rebuild

- Technical skills: if the community has easy and long-term access to the skills to carry out repairs

- Equipment and Spare parts: If the community has access to the necessary equipment and spare parts for their project

Degree to which the roles of people using and managing the scheme were defined and regulated (Separation of Roles)

- Purchaser - provider: Measures community ability and willingness to pay for the water service

- Asset Holding Authority (AHA) and Provider: Assessing contracting procedures, if they exist and how they work

- Regulation \& Participation: If the community is being involved and if there is a clear evidence of working regulatory mechanism.

Figure 1. Three components of Sustainability Snapshot and Separation of Roles.

Each factor is divided into three statements or rankings. The respondents are asked to analyze their situation regarding each factor and discuss which statements best fit their situation. A score of " 3 " is given to the ideal situation and a score of " 1 " is given to the least ideal situation. Then the participants are asked to discuss what could be done to improve the score for each factor. Table 5 provides an example of three statements regarding finance.

\begin{tabular}{|c|l|}
\hline \multicolumn{2}{|l|}{ Finance - Which of the following is applicable to the type of water point in question? } \\
\hline Ranking & Statement \\
\hline 1 & No funds available for maintenance when needed. \\
\hline 2 & Funds available but not sufficient for the most expensive maintenance process. \\
\hline 3 & Fund available and sufficient for the most expensive maintenance process. \\
\hline
\end{tabular}

Table 5. An example of ranking system from Sustainability Snapshot.

The scores from each community were entered into a spreadsheet and the data were analyzed using Excel and SPAA computing programs. Based on the study of 30 different communities in Tanzania, the investigators made the following conclusions: 
- Problems with sustainability are highly associated with lack of finance to carry out major rehabilitation work, lack of technical personnel at a project level, and inaccessibility of spare parts.

- The sustainability is also linked with the internal governance issue where community members must understand the roles and responsibilities of each group involved in the management of the system and they must have a regulatory mechanism to hold those groups accountable.

- The nine regulatory issues that must be included in any regulatory framework should include; 1) memorandum of understanding with the district, 2) external audit report, 3) external assessment on performance, 4) contract, 5) internal audit report, 6) report to general assembly, 7) setting \& reviewing prices, 8) meeting minutes, and 9) users voting out underperforming managers

\subsection{The Institutional Support Mechanism}

Field experiences and extensive studies by researchers and organizations have revealed that there is a limitation to the CM model and most communities need external support to ensure sustainability of RWS (IRC, 2003; Lockwood, 2004). Although community members can, and should, assume the majority of responsibility to maintain their water systems, in most cases they will need some kind of external assistance. The Institutional Support Mechanism (ISM) refers to the capacity of an organization to provide long-term support to rural communities without undermining the responsibilities of community management or creating long-term dependency (Lockwood 2002).

The organizations with the ISM could provide communities with technical advice, additional training, monitoring and evaluation, and coordination with other institutions. The follow-up could also come in the form of providing support with legal, environmental and health issues. The challenge is to determine the scope and frequency of external assistances as it varies significantly depending on the internal and external factors of each community. Following is a case study on how decentralized model of ISM was implemented in rural areas in Honduras (Trevett, 2001). 


\subsubsection{Technician in Operation and Maintenance Program in Honduras, 2001}

Similar to many other developing countries, up to the early 1990s, the institutions involved in RWS in Honduras have mainly focused on the construction of infrastructure and the training of community members was only conducted during the construction phase. In 1992, the National Water Supply and Sewage Company (SANAA) completed a study on operation and maintenance (O\&M) of rural water systems and identified the following common problems:

- Community water boards were not meeting regularly.

- The monthly tariff, if collected, was not adequate to cover routine maintenance cost.

- An operator responsible for upkeep was not being designated.

- Water systems were not being chlorinated.

The results from this study encouraged SANAA, with significant technical and financial assistance from USAID, to launch a pilot program called the Technician in Operation and Maintenance (TOM) project. This program took place from 1993 to 1995. The TOM project was designed based on the "circuit rider" program utilized by the National Rural Water Association (NRWA) in the United States, where a mobile water technician is assigned to a set number of water systems in a state. This mobile water technician referred to as TOM in Honduras, made periodic visits to each community, providing technical and administrative advice through informal and hands-on trainings. This pilot program was considered a success because the communities that received help from the roaming technicians were able to improve their water systems. As a result, the program was expanded to the national level. Today, the TOM project supports 4023 community-managed RWS that serve approximately 2 million people.

The applicants for the TOM project must be males, 20-30 years of age with a pre-university qualification in social work or primary education. In order to be accepted into the program, the new recruits must successfully complete an intensive 12-week training program consisting of theoretical and practical work in the following themes:

- Community motivation and participation

- Educational communication

- Water and sanitation concepts

- Basic technical concepts

- Water system construction and components

- Topography

- Engineering plans 


\section{- $\quad$ Operation and Management (O\&M)}

The initial strategy of the TOM project was to produce an inventory of all rural piped-system and complete an in-depth evaluation of each system to determine its operational status and classify each system according to Table 6. All this data was entered into a specifically designed database called SIAR (Rural Water Information System). The database containing detailed information of all water systems proved to be a very useful planning tool.

\begin{tabular}{|c|l|l|}
\hline Category & \multicolumn{1}{|c|}{ Description } & \multicolumn{1}{c|}{ Action } \\
\hline A & $\begin{array}{l}\text { All the physical components of the system } \\
\text { are working well. The water board meets } \\
\text { regularly Tariffs are fixed, are adequate, } \\
\text { and are collected. The Water supply is being } \\
\text { chlorinated, and water quality standards are } \\
\text { met. There is continuous or regular service. }\end{array}$ & $\begin{array}{l}\text { Motivate the water board to } \\
\text { continue the good work. }\end{array}$ \\
\hline B & $\begin{array}{l}\text { The system may or may not be functioning. } \\
\text { There are operational problems that can be } \\
\text { resolved without major investment With } \\
\text { minimal effort on the part of the TOM, the } \\
\text { system can be moved up to "A" category. }\end{array}$ & $\begin{array}{l}\text { Work together with the water } \\
\text { board to resolve the minor } \\
\text { problems in administration, } \\
\text { operation, and maintenance. }\end{array}$ \\
\hline C & $\begin{array}{l}\text { The system may or may not be functioning. } \\
\text { There are operational problems, and there } \\
\text { may be technical problems with the water } \\
\text { supply. Moving the system up to "A" } \\
\text { category could require certain investments, } \\
\text { which are within the economic capacity of } \\
\text { the community. }\end{array}$ & $\begin{array}{l}\text { Work together with the water } \\
\text { board to resolve the minor } \\
\text { operational problems. Advise } \\
\text { the board on the necessary } \\
\text { system improvements, and } \\
\text { their cost, in order for the } \\
\text { community to raise the } \\
\text { required capital. }\end{array}$ \\
\hline D & $\begin{array}{l}\text { The system is not functioning. There are } \\
\text { many problems. Moving the system up to } \\
\text { "A" category requires substantial } \\
\text { investment, probably greater than the } \\
\text { economic capacity of the community. }\end{array}$ & $\begin{array}{l}\text { Report the situation to the } \\
\text { regional SANAA office. Little } \\
\text { can be done by the TOM. }\end{array}$ \\
\hline
\end{tabular}

Table 6.

Water System Classification and Remedial Action.

Based on the ranking from Table 6, the TOM works with the water boards of each community to develop an action plan discussing trainings and tasks that community would need to complete in order to move up from category to another. The TOM does not carry out the actual repairs themselves, but rather offer advice and supervision so that communities can repair them on their own. Once the water board reaches the " $\mathrm{A}$ " category, the TOM organizes a community meeting to present a diploma from SANAA to the board and motivate them to continue the good 
work in the presence of their fellow community members. The diploma is renewed each year if the system is able to maintain its " $\mathrm{A}$ " status.

Each TOM is responsible for an average of 50 communities and is expected to visit each community at least twice a year. The duration of each visit varies depending on the needs of each community. Since the TOM is perceived as a representative from an institution with certain authority in water-related issues, they are in a position to assist in conflict resolution. The TOM may play a critical role in mediating internal and external conflicts within a community such as community members challenging the water board's authority or dispute over watershed use.

Establishing adequate tariffs to cover recurrent cost and convincing people to pay has been one of the biggest challenges for the TOM. After generations of taking water free from unprotected springs or streams, paying for water is a new concept for many rural community members. This problem is exaggerated by certain paternalistic development organizations that require very little financial contribution from the community members or even pay community laborers to build their own water system.

\subsection{Water Sector in Rural Panama}

\subsubsection{Overview}

The Republic of Panama, a small isthmus country located in Central America, is one of the richest and fastest growing economies in Latin America (World Bank, 2007). Social indicators such as adult literacy, schooling and life expectancy have been improving significantly, but not everybody shares this progress. Panama has one of the highest inequalities in income in the world with $37.3 \%$ of the population living beneath the national poverty line (UNDP, 2009). Within the seven indigenous groups that make up 8\% of the total population, 98\% are considered to live in poverty while $90 \%$ could fall in the category of extreme poverty. The living standard and social indicators in certain rural areas, especially within the indigenous population, are comparable to the extreme poor in sub-Saharan Africa with high rates of infant and maternal mortality, infectious diseases, and malnutrition (World Bank, 2007).

The statistics regarding water and sanitation coverage also reflects this inequality. The percentages of the urban population with access to an improved water source and adequate 
sanitation are $97 \%$ and $75 \%$ respectively, while the rural population with access is $83 \%$ and $51 \%$ respectively (WHO, 2010). The situation is believed to be much worse in the indigenous area where only $56 \%$ of households have running water and $31 \%$ have latrines (World Bank, 2007). Even these figures might be a gross overestimate, as many systems are not working as originally designed because of lack of upkeep, poor construction or rapid population growth.

\subsubsection{Ministry of Health}

The Ministry of Health (MINSA) is formally responsible for formulation of sector policy and promotion of rural water supply and sanitation. A diagnosis by the World Bank (2007) found that on the national level, the MINSA's department of rural water and sanitation lacks leadership and strategic vision for the sector. Consequently, there is no well-articulated, longterm plan to increase the coverage in rural areas.

Although each province in Panama has a regional MINSA office with its own department of water and sanitation, the highly centralized nature of Panamanian institutions gives very little autonomy to these regional offices. For example, the national office must approve all projects before the regional office can carry them out. The regional offices also constantly complain about the lack of funding, staff, and construction materials necessary to provide adequate service to the hundreds of dispersed rural communities in the province (Braithwaite, 2009).

Lockwood (2003) noted that frequent personnel changes based on the election results are common in many countries, making it difficult to achieve any capacity building of civil servants and create institutional memory. This is also true with Panamanian agencies where nepotism and political favoritism often dictate the hiring processes, causing the majority of workers in both the national and local offices to be replaced after an election. As a result, many of the regional engineers and technicians have little or no formal training.

\subsubsection{Community Managed Rural Water Systems in Panama}

The mountainous terrain and abundance of springs and streams in Panama make gravity-fed water distribution systems a viable option for most rural communities. It is rare to see community managed pump systems or wells. The World Bank report (2007) found that many rural water systems were built without taking into account seasonal variation, forcing many users to revert to using the traditional unprotected springs and streams during the dry season. 
The cost of construction per household is much lower in larger and compact communities, and it is much more expensive in small and dispersed communities located in areas of difficult access.

A typical water committee consists of democratically elected members of the community with the following positions: president, vice-president, secretary, treasurer, fiscal (oversee checks and balances), and vocal (communicate meeting time and work days to rest of the community). In order to further promote and standardize community managed water systems, the national government passed a resolution establishing roles and responsibilities for both water committees and users (MINSA, 1994). The government was also going to officially recognize each water committee as a legal entity and label them as a JAAR (J unta Administradoras de Acueductos Rurales).

MINSA is responsible for providing water committees with training and administrative support as well as processing the paper work to establish them as legal entities. However, this seldom happens as evidenced by the low number of fully functioning water committees with the official JAAR status. Most community members have shown limited knowledge and skills to complete the responsibilities established under JAAR requirements (Braithwaite, 2009). There is also very little incentive to volunteer as a water committee member, as the positions provide no reward and puts them in a focal point of community criticisms once the water system runs dry. These factors, combined with insufficient funds generated by tariffs, result in many systems with short productive lives.

\subsection{Peace Corps Panama - Environmental Health Program}

The Environmental Health (EH) program is one of the five technical areas of Peace Corps (PC) Panama. The EH volunteers live in remote communities in Panama for two years and assist community members to improve their standard of health and access to water and sanitation through participatory development methods (Peace Corps Panama, 2010). In terms of water systems, volunteers mainly work with gravity flow piped systems. About $70 \%$ of the volunteers are assigned to indigenous communities, while the remaining $30 \%$ are assigned to other impoverished communities. Before arriving in the community, the volunteers must complete an intensive 10-week training course that consists of the following topics: formal instructions in Spanish and an indigenous language; technical training in water systems, sanitation, health education and participatory development; and cross-cultural adaptation skills. 
If a community wants assistance from the PC for a water project, they must first solicit for a volunteer. Upon arriving in the community, the volunteers must integrate themselves into the community and perform a community health assessment with the community members. In order to carry out a water project, the community must participate in the decision-making process of the project planning and implementation phase, and contribute at least $25 \%$ of the total project cost by providing non-skilled labor and locally available resources such as timber, land, and food for workers. Being involved in this whole process is believed to contribute to capacity building of community members and instill sense of ownership. The NGO Waterlines has often provided the funding to pay for the other $75 \%$ of project cost for construction materials, transportation, and skilled labor.

\subsubsection{Water Committee Training Seminar}

Throughout the project life cycle, volunteers must also help organize a water committee and train them on various technical and administrative skills necessary to maintain a water system. This training process has been further strengthened in the last two years through standardization of water committee training seminars. The curriculum for the training seminar consists of four main themes: accounting and transparency, infrastructure, watershed management, and community management and leadership. Each session plan was designed to be appropriate for the cultural and educational background of rural community members in Panama ${ }^{2}$.

\subsubsection{The Environmental Health Program Niche}

The niche for the EH program is that volunteers typically work in remote small to mid size communities (100 to 1,000 inhabitants) that often are overlooked by large government and donor projects. Most government institutions are less inclined to work in isolated communities due to high costs of centralized project planning and implementation structure (Schweitzer, 2009). The $\mathrm{EH}$ volunteers are able to work in these areas because the overhead cost for project management and design is essentially subsidized through a volunteer's living allowance; which is paid for by the US government. The only monetary cost for projects are construction materials, skilled labor and transportation, as the community is required to donate $25 \%$ of the project cost through labor and other locally available resources. As a result, the prices that

\footnotetext{
${ }^{2}$ See Training water committees in Bocas del Toro, Panama: A case study of Peace Corps Volunteers' initiative to improve rural water system management by Braithwaite (2009) for more information regarding EH water committee training seminars.
} 
appear on the budgets for $\mathrm{EH}$ water and sanitation projects are significantly less expensive than the MINSA project budgets. Since it is difficult to compare costs for water projects because the scale of systems varies from one to another, the sanitation projects provide a better example to support this point. The budget for a volunteer sanitation project normally requires $\$ 70$ per latrine, while the MINSA project requires $\$ 300$ per latrine. Once again, this is because the US government subsidizes the overhead cost for project management and design through the volunteer's living allowance and since communities must still contribute $25 \%$ of the project cost, the danger of over-designing and over-building is minimized.

\subsubsection{Limitations and Challenges}

Most volunteers arrive to the country with limited or no experience in participatory community development and water system projects as well as limited language skills. Even an intensive 10week training is not enough to prepare each volunteer as a fully capable development practitioner, water technician and health promoter fluent in Spanish. It is also unrealistic to assume that all volunteers possess the necessary personal traits such as cultural respect, humility, patience, flexibility and excellent communication ability to become a successful development practitioner. The volunteers must take the "learning by doing" approach upon arriving to their communities and acquire skills and knowledge through mistakes and difficult experiences. After two years in the same community, most volunteers gain a wealth of local knowledge and experience, but their services have ended and they are replaced by a new set of volunteers starting from the beginning. As a result, the Peace Corps have always suffered from the loss of institutional memory due to relatively high turnover rates. 


\section{Chapter 3 - Study Methodology}

The methodology established for the purpose of this study does not intend to estimate or measure the sustainability level of RWSs as in other methodologies developed by PRONSAR (2003), Mukherji and van Wijk (2003), and Schweitzer (2009). Their conclusions on the level of sustainability reflect the variables as measured by their study indicators (Sara and Katz, 1997). Thus, their results are only predictions of sustainability based on their respective definition of sustainability (as summarized in Table 7) and its indicators, rather than observable measures of long-term sustainability.

\begin{tabular}{|l|l|}
\hline Methodology & Definition of Sustainability \\
\hline PRONSAR, 2003 & $\begin{array}{l}\text { The infrastructure is in optimal condition continuously } \\
\text { providing excellent quantity and quality of water. The water } \\
\text { committee is able to administer the system effectively and has } \\
\text { equal representation of men and women. The beneficiaries are } \\
\text { satisfied with the system and cooperate with the maintenance } \\
\text { work. }\end{array}$ \\
\hline MPA (Mukherji and & $\begin{array}{l}\text { 1.) Continuous, satisfactory functioning, and use in health- } \\
\text { promoting and environmentally sound manner. } \\
\text { 2.) Everyone has equal voice and choice in decision-making, } \\
\text { equal access to information/external inputs/benefits from } \\
\text { projects, and shares burdens and responsibilities fairly. }\end{array}$ \\
\hline $\begin{array}{l}\text { Sustainability Analysis } \\
\text { Tool } \\
\text { (Schweitzer, 2009) }\end{array}$ & $\begin{array}{l}\text { 1.) Equitable access amongst all members of a population to } \\
\text { continual service at acceptable levels (quantity, quality, and } \\
\text { access location) providing sufficient benefits (health, economic, } \\
\text { and social). } \\
\text { 2.) Require reasonable and continual contributions and } \\
\text { collaborations from service beneficiaries and external } \\
\text { participants. }\end{array}$ \\
\hline
\end{tabular}

Table 7.

Definition of sustainability according to each methodology.

Instead of attempting to estimate a level of sustainability, the methodology developed for the purpose of this research consists of collecting data on observable and relevant aspects of gravityfed water distribution systems and water committees. The goal is to allow the investigator and community members to work together to identify problems that communities face in maintaining their water system. Following are some of the common problems in communitymanaged water systems that the methodology will attempt to diagnose (Lockwood, 2002):

- Problems with the physical infrastructure due to poor construction or lack of upkeep. 
- Financial problems such as failure to collect tariffs, misuse and mismanagement of funding, and income generated not sufficient to cover all operation and maintenance cost.

- Managerial or organizational problems that include; politicization or breakdown of water committees, lack of personal interest or incentive to participate, and absence of knowledge transfer between committee members.

- Environmental problems resulting in deterioration and reduction of water quality and quantity.

\subsection{Data Collection Method}

The data collection method was developed to assess the physical state of the gravity flow water system infrastructure as well as the managerial, financial and technical capacity of the community members. The methodology relies on direct observation and informal conversations executed by the investigator to collect all the relevant information in a short period without any field assistants.

Considerable effort was made to avoid a rigid and prescriptive "man with a clipboard" approach, where an outsider comes into a community with a few standard questions and leaves again without attempting to promote a meaningful involvement of the community members (Lockwood, 2003). Instead, the method emphasizes informal and reciprocal dialogue between the investigator and community members. Rather than simply extracting information from the community members, this method calls for the investigator and community members to be involved in a conversation to openly share experiences, opinions and best practices.

For the reasons mentioned above, this study did not include formal surveys and interviews. The literature review and author's experience revealed the difficulty of obtaining reliable data through these methods (Mukherji and van Wijk, 2003; Sugden, 2003). Many people tend to provide answers that they think the investigators want to hear rather than express their true opinion. There is also a problem with strategic bias where the respondents believe that it is more advantageous to stretch the truth or deceive the questionnaire. Others may feel intimidated or offended by an outsider asking personal questions and writing down the answers. These methods are also criticized for their tendency to treat community members as objects being studied. 
In order to circumvent the negative aspects and limitations of formal surveys and interviews, many development practitioners utilize more participatory approaches. These approaches encourage community members to become an active investigator in critically analyzing their current situation and discovering their own solutions (Freire, 1970; Mukherji and van Wijk, 2003). Some examples of participatory activities include social mapping, Venn diagram, transect walk, focus group meeting, pocket voting, and card sorting.

However, participatory activities mentioned above may not always be feasible or practical. For example, the methodology for participatory assessment (MPA) mentioned in the previous chapter requires a complete team of investigators trained and well-experienced in facilitating participatory activities, staying in one community for five days. This team should consist of at least one water and sanitation engineer, one anthropologist, both genders, and somebody from the same ethnic and cultural background of the communities being studied. Even if the investigators had the time and resources to assemble such a team, it would not function unless the community is available or willing to participate in such activities.

\subsection{Benchmarking}

For the purpose of this study, a benchmark scoring system similar to MPA was developed specifically for the gravity-fed water distribution systems and water committees in rural Panama. Benchmarking refers to the use of an ordinal scale to collect and organize data. For each indicator, a 5-point scale is assigned with " 5 " being the most ideal situation and "1" being the least ideal. In case the situation falls somewhere in between two consecutive points, it can choose to score midway between the two situations concerned and provide a detailed explanation of the situation. This descriptive ordinal scoring helps to capture even hard to measure issues by quantifying qualitative data (Mukherji and van Wijk, 2003). Putting numbers on qualitative data also allows for comparison of performances between the communities and more advanced statistical analysis.

Having benchmarks for different aspects of water systems allows the community members to identify their current situation and visualize what an ideal situation would look like (Sugden, 2003). This will help to provoke discussions on what they want to improve and how to achieve it, similar to the methodology developed by WaterAid. This tool could also help other EH 
volunteers to perform an impact assessment in their respective communities or measure the effectiveness of water committee training programs.

Relevant indicators were chosen based on the literature review and the author's three-year experience in Panama. Each indicator must be easy to measure through direct observations and informal conversations. Indicators measured during each community visit are summarized in Table 8.

\begin{tabular}{|lc|}
\hline & Indicators \\
\hline Watershed & System Reliability \\
Source Capture & Willingness to Pay \\
Transmission Line & Accounting and Transparency \\
Storage Tank & System Maintenance \\
Distribution System & Active Water Committee Members \\
\hline
\end{tabular}

Table 8. $\quad$ Ten indicators measured in the methodology.

The scoring system should be used as a guideline to distinguish different characteristics of ideal and not-so-ideal water systems and water committees. It serves as a checklist of key points to be observed or discussed during transect-walks and informal conversations. This scoring system is not meant to be scientifically rigorous, as the ranking uses vague phrases such as "some tree coverage" or "enough water". Since the ultimate goal of this evaluation is to allow the community members to identify their situation and take a corrective action, the issue of accuracy and detailed information must be viewed within this context (Narayan, 1993). For example, whether tree coverage in the watershed is 10.4 or 50.2 trees/hectare may not be relevant for most community members, but whether or not the watershed is covered in lush forest might be more appropriate in the local context.

\subsection{Indicators}

\subsubsection{Watershed}

The analysis of watershed consists of two crucial aspects: the current state of area surrounding the source, and what initiatives the community members have taken to ensure that the area remains protected from deforestation or contamination. Before starting any water projects, the community members must prepare a written contract signed by the landowner to keep this area protected. However, land disputes are a common problem in these areas as the landowners are 
seldom willing to give up that much land. This problem only worsens when the landowner does not directly benefit from the water source.

\begin{tabular}{|c|l|}
\hline Score & \multicolumn{1}{|c|}{ Score Description } \\
\hline 1 & $\begin{array}{l}\text { No tree coverage, presence of contaminants nearby (open defecation or } \\
\text { latrines, animals, agrochemicals), no formal agreement with the owner }\end{array}$ \\
\hline 2 & No tree coverage, no contaminants, no formal agreement with the owner \\
\hline 3 & Some tree coverage, no contaminants, verbal agreement with the owner \\
\hline 4 & $\begin{array}{l}\text { Area is covered with lush forest or being reforested, no contaminants, verbal } \\
\text { agreement with the owner }\end{array}$ \\
\hline 5 & $\begin{array}{l}\text { Area is covered with lush forest or being reforested, no contaminants, formal } \\
\text { written agreement with the land owner to keep the area protected }\end{array}$ \\
\hline
\end{tabular}

Table 9. Scoring Scale for Watersheds. Contaminants can be derived from the following sources: open defecation or latrines, animals, agrochemicals.

There might be situations where a community has excellent tree coverage and no agreement with the owner, or no tree coverage with a written contract with the owner to keep the area protected. In most cases, there will not be perfect match between the score descriptions and the particular situation in each community. Therefore, the purpose of this study is not mechanically assign scores to each community. The most important aspect is that the investigator and community members engage in a discussion and look for solutions regarding this matter. For the scoring purpose, the investigator can extrapolate the score based on their best judgment and clearly explain in the field note a detailed description of the situation and a rationale for assigning that score. This technique is applied to other indicators as well.

\subsubsection{Source Capture}

The purpose of spring box is to protect the spring source from runoff and capture water from the source. There is a tendency for water to carve out a new path away from the catchment area causing minor or major water loss. Poorly made spring boxes are also vulnerable to surface water entering the catchment area during a heavy storm. In certain cases, it is not necessary to capture all the water from spring or creek sources with an abundance of water. In this case, as long as sufficient water is being captured to meet the community need, protection from runoff and damages would determine the score. This scoring system is only applicable to spring sources and is not relevant for stream sources. 


\begin{tabular}{|c|l|}
\hline Score & \multicolumn{1}{c|}{ Score Description } \\
\hline 1 & Not protected from runoff, majority of water not captured \\
\hline 2 & Runoff could enter the source, majority of water not captured \\
\hline 3 & No runoff entering the source, some water not being captured \\
\hline 4 & No runoff entering the source, majority of water captured, some leaks \\
\hline 5 & No runoff entering the source, all the water captured, no leaks \\
\hline & Scoring Scale for Source Protection and Capture. \\
\hline
\end{tabular}

Table 10. Scoring Scale for Source Protection and Capture.

\subsubsection{Transmission Line}

The transmission line refers to the main pipeline connecting source and tank. Terrain with many rocks or roots often makes it difficult to bury all the sections. Exposed tubes or pipes could also result from poor construction management or erosion. Since many transmission lines tend to be farther away from the community and cover long distances, the damages are often hard to detect and repair. Even when the damages are repaired, there are often still some leaks due to poorly made joints or lack of glue. Since air release valves are fairly expensive and hard to find, many communities fix air blockage problems by puncturing a small hole in the tube, which is a problem because of water loss and vulnerability to contamination.

\begin{tabular}{|c|l|}
\hline Score & \multicolumn{1}{|c|}{ Score Description } \\
\hline 1 & $\begin{array}{l}\text { Majority of tubes are exposed, significant amount of water being lost from } \\
\text { damages or poorly made joints, uncovered hole for air blockage }\end{array}$ \\
\hline 2 & $\begin{array}{l}\text { Majority of tubes are exposed, some water being lost from damages or poorly } \\
\text { made joints, uncovered hole for air blockage }\end{array}$ \\
\hline 3 & $\begin{array}{l}\text { Some exposed tubes, some water being lost from damages or poorly made } \\
\text { joints, hole for air release covered with a piece of stick or other smaller } \\
\text { material }\end{array}$ \\
\hline 4 & $\begin{array}{l}\text { Majority of tubes buried, little water being lost from damages, joints well } \\
\text { made, air release hole covered with a piece of stick or other smaller material }\end{array}$ \\
\hline 5 & $\begin{array}{l}\text { All tubes buried, no leaks, joints well made, air release valves installed in } \\
\text { proper place }\end{array}$ \\
\hline
\end{tabular}

Table 11. Scoring Scale for a Transmission Line.

\subsubsection{Storage Tank}

The purpose of the storage tank is to store water during low-demand hours when most households have their taps closed, in order to provide additional supply during the peak-use time. The tank size should be calculated based on the peak demand and source output. Most rural water systems in Panama utilize a square tank built with concrete blocks. In these square tanks, the corners of tanks tend to leak more. 
Conducting scheduled cleanings of the tanks is an indicator of community initiative regarding system maintenance. Neglecting to clean the tank for a long period can lead to accumulation of sediments in the tank and introduction of sediments into the distribution system. There may also be problems with algae and bacteria growing inside the tank causing potential health risks to the community.

\begin{tabular}{|c|l|}
\hline Score & \multicolumn{1}{|c|}{ Score Description } \\
\hline 1 & Tank size is too small, major leakage observed, never have been cleaned \\
\hline 2 & Tank size too small, some leakage observed, cleaned less than once a year \\
\hline 3 & Sufficient tank size, very little leakage observed, cleaned less than once a year \\
\hline 4 & Sufficient tank size, no leakage observed, cleaned at least once year \\
\hline 5 & Sufficient tank size, no leakage observed, cleaned periodically \\
\hline
\end{tabular}

Table $12 . \quad$ Scoring Scale for a Storage Tank.

\subsubsection{Distribution System}

From the storage tank, water is distributed to each household through gravity. Proper tube size and placement is essential for equitable access amongst households, especially when houses are spread apart. Houses located at higher elevations or farther away from the tank are the first to experience major water shortages. Additional household connections without proper design exaggerate this problem. Individual household owners are typically responsible for burying the connection line from the main line to their houses, as well as replacing leaky or broken taps. There are many irresponsible owners who neglect to bury their tubes or replace their taps. In certain cases, there are even owners who do not turn off their tap even when other parts of the community are suffering from water shortages. Finally, many systems do not have sufficient control valves in the distribution system, making it harder to repair damages by isolating one section of the distribution system. 


\begin{tabular}{|c|l|}
\hline Score & \multicolumn{1}{|c|}{ Score Description } \\
\hline 1 & $\begin{array}{l}\text { Leaky or broken taps, no valves, major inequity of water pressure and flow, } \\
\text { exposed and leaky tubes }\end{array}$ \\
\hline 2 & $\begin{array}{l}\text { Leaky or broken taps, no valves, some inequity of water pressure and flow, } \\
\text { exposed and leaky tubes }\end{array}$ \\
\hline 3 & $\begin{array}{l}\text { Some leaky or broken taps, control valves, some inequity of water pressure } \\
\text { and flow, exposed tubes, minimum leaks }\end{array}$ \\
\hline 4 & $\begin{array}{l}\text { Adequate pressure and flow at all houses, control valves, very little leaky or } \\
\text { broken taps, tubes buried, minimum leaks }\end{array}$ \\
\hline 5 & $\begin{array}{l}\text { Adequate pressure and flow at all houses. Physical infrastructure is intact } \\
\text { including; tap stands, service line control valve, main line control valves, tubes } \\
\text { are buried. }\end{array}$ \\
\hline
\end{tabular}

Table 13.

Scoring Scale for a Distribution System.

\subsubsection{System Reliability}

System reliability refers to how much access each household has to water throughout the year. Phrases such as "not enough water" or "sufficient water" on the score description may sound vague to most readers or practitioners who want to use this tool kit. In other evaluation methods, system reliability is often measured by the number of hours or quantity of water available per household per day. However, these data do not necessarily reflect how well the system is functioning or being maintained in many communities in Panama. For example, in communities with limited source output, it is commonly accepted that water from aqueducts is only for drinking and cooking, while bathing and washing clothes is done in the nearby river or creek. For them, it is not practical to expect that a water system could provide 50-100 \{liters/ person-day\}.

System reliability is estimated based on what is considered as sufficient water for each community and how the changes in the season affect the water availability. The output of many sources drops significantly during the dry season, which typically lasts from the end of December to March. Even in the province of Bocas del Toro where it rains year round, many communities suffer from water shortages even after a few weeks without any rain. When the output declines or when there is too much water loss from leakage, not everybody in the community is equally affected by the water shortages. Once again, the houses located farther away from the tank or at higher elevations are the first ones to suffer from water shortages. 


\begin{tabular}{|c|l|}
\hline Score & \multicolumn{1}{|c|}{ Score Description } \\
\hline 1 & Majority of users do not have enough water all year around \\
\hline 2 & $\begin{array}{l}\text { Majority of users do not have enough water during the dry season, some users } \\
\text { have enough water during the rainy season }\end{array}$ \\
\hline 3 & $\begin{array}{l}\text { Some users have sufficient water during the dry season, majority of users have } \\
\text { enough water during the rainy season }\end{array}$ \\
\hline 4 & $\begin{array}{l}\text { Majority of users have sufficient water even during the dry season, everybody } \\
\text { has enough water during the rainy season }\end{array}$ \\
\hline 5 & All users have sufficient water even during the dry season \\
\hline
\end{tabular}

Table 14. Scoring Scale for System Reliability.

\subsubsection{Willingness to Pay}

Willingness to pay is determined by the percentage of monthly quotas that were paid by the community in a given year. It is common that many people do not pay their monthly tariffs on time and pay for multiple months in one payment. Therefore, it will be more practical to add up all the monthly tariffs that a community owes in a year and observe what percentage of it they were able to collect that year. For example, a community with 20 household connections would have to collect 240 monthly payments per year. Assuming that a treasurer or a president has a ledger, dividing the total number of monthly tariffs in a given year by 240 would determine the percentage.

The monthly fee is typically determined collectively in a community meeting. The community members will set a fee based on what they believe is affordable for even the poorest households. That is why in most indigenous communities, the tariff is set at $\$ 0.25$ or $\$ 0.50$ per month. Therefore, everyone should have the ability to eventually pay the monthly tariffs, and the level of delinquency is assumed to represent willingness to pay (Schweitzer, 2009).

\begin{tabular}{|c|c|}
\hline Score & Score Description \\
\hline 1 & $\mathrm{X}<20 \%$ \\
\hline 2 & $20 \%<\mathrm{X}<50 \%$ \\
\hline 3 & $50 \%<\mathrm{X}<70 \%$ \\
\hline 4 & $70 \%<\mathrm{X}<90 \%$ \\
\hline 5 & $\mathrm{X}>90 \%$ \\
\hline
\end{tabular}

Table 15. Scoring Scale for Willingness to Pay. The percentage is derived from dividing total number of monthly tariffs collected in a given year by total number of monthly tariffs that should be collected in year based on the number of houses. 


\subsubsection{Accounting and Transparency}

Each water committee should have a well-organized ledger for the monthly payments, an accounting book for keeping track of money received and earned, and receipts of all the purchases made. All these financial activities should be reported to the community periodically. Once again, this information could be difficult to collect especially if the treasurer or president is not present at the house during the time of investigator's visit.

\begin{tabular}{|c|l|}
\hline Score & \multicolumn{1}{|c|}{ Score Description } \\
\hline 1 & No ledger, no receipts, never reports to community \\
\hline 2 & Ledger, no receipts kept, never reports to community \\
\hline 3 & $\begin{array}{l}\text { Ledger, some receipts are kept but disorganized, reports to community once a } \\
\text { year }\end{array}$ \\
\hline 4 & $\begin{array}{l}\text { Ledger, some receipts are kept and well organized, and report to community } \\
\text { once a year }\end{array}$ \\
\hline 5 & $\begin{array}{l}\text { Ledger, all receipts kept and well organized, reports to community throughout } \\
\text { the year }\end{array}$ \\
\hline
\end{tabular}

Table 16. Scoring Scale for Accounting and Transparency.

\subsubsection{Maintenance}

Funds collected through tariffs should be used to repair damaged or leaky tubes, tanks, spring boxes, and valves. However, neglecting these responsibilities are common in poorly managed water systems. Although it would be ideal to repair the damages immediately, many communities seem to repair them periodically or only when there is a major water shortage and the rest of the community is complaining furiously.

\begin{tabular}{|c|l|}
\hline Score & \multicolumn{1}{|c|}{ Score Description } \\
\hline 1 & Damages are never repaired \\
\hline 2 & Damages are only repaired when there is a major water shortage \\
\hline 3 & Damages are repaired less than once a year \\
\hline 4 & Damages are repaired periodically, multiple times a year \\
\hline 5 & Damages are repaired immediately \\
\hline
\end{tabular}

Table 17. Scoring Scale of System Maintenance.

\subsubsection{Number of Active Committee Members}

According to Panamanian law, each community is required to elect six members for the water committee. The positions include president, secretary, treasurer, fiscal, and two vocals. Although most communities have all six positions filled on paper, it does not necessarily guarantee that each member is active. Members who regularly assist in meetings and workdays 
are considered as active members. Unfortunately, this scoring system cannot calculate the impact of one charismatic leader. In many cases, one active leader holds the committee together. If this leader ever quits or leaves town, the committee becomes ineffective.

Table 18. Scoring Scale for Number of Active Water Committee Members.

\begin{tabular}{|c|c|}
\hline Score & Score Description \\
\hline 1 & 1 member \\
\hline 2 & 2 members \\
\hline 3 & 3 members \\
\hline 4 & 4 members \\
\hline 5 & 5 or more members \\
\hline
\end{tabular}

\subsubsection{Potential weaknesses}

This data collection method may be questioned for sacrificing too much rigor for simplicity. For certain uses, it may require more detailed quantitative analysis. The argument could also be made that this methodology might still be too confusing for a rural population with a limited education level. In this case, a visual representation of the score descriptions would allow more people to participate in the investigation process. 


\section{Chapter 4 - Post-Project Assessment of 28 Rural Water Systems}

Using the methodology established in the previous chapter as a guideline, a post-project assessment of 28 community-managed water systems in rural Panama built or rehabilitated by PCVs and funded by the NGO Waterlines has been completed by the author of this report. The communities were identified based on the list of past projects organized by the Peace Corps EH program director. Figure 2 is a map showing the location of all the communities visited for the purpose of this study. The map was prepared by entering the GPS coordinates from each community into the Google Earth program. Each community is marked with a yellow pin.

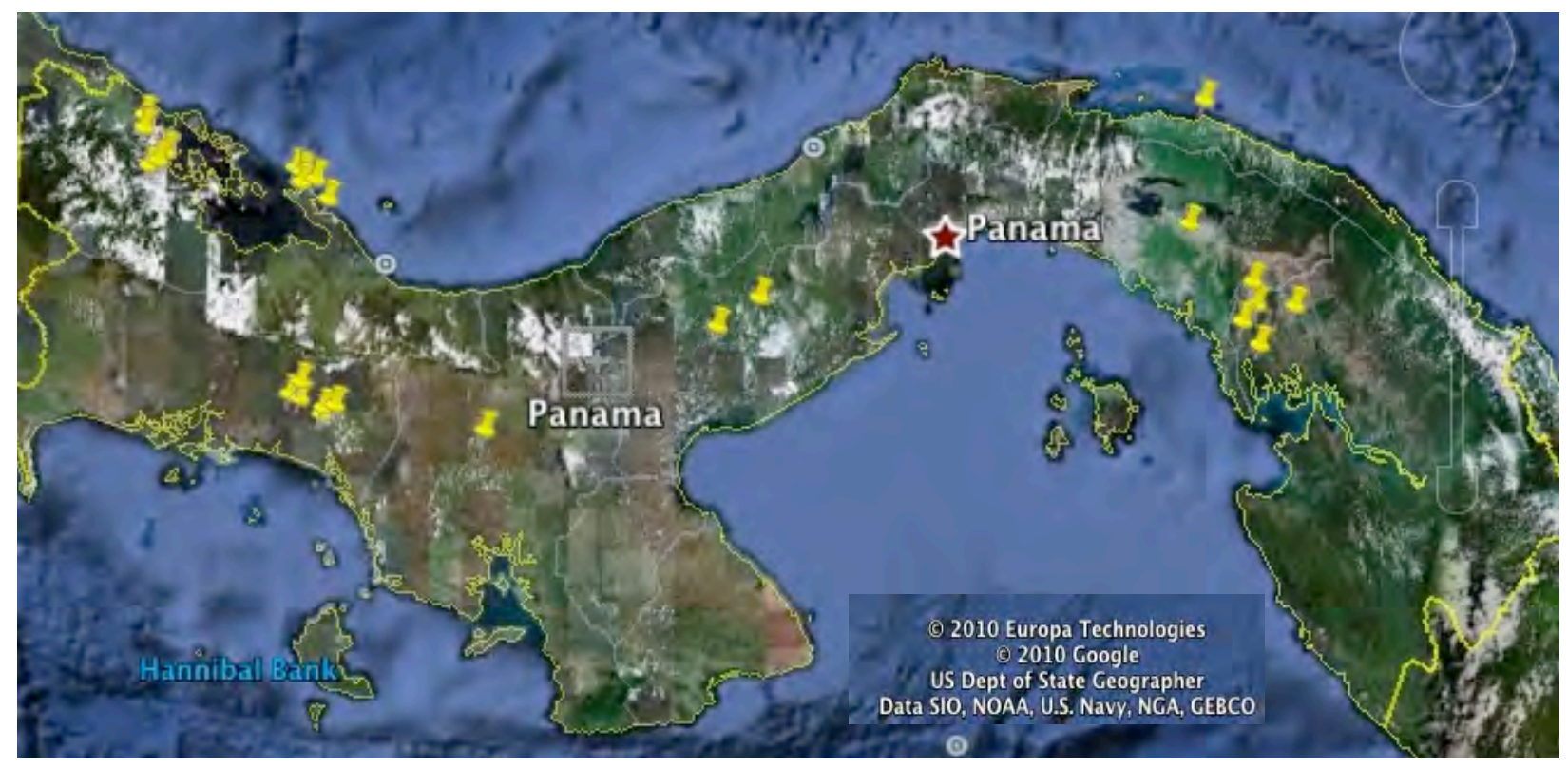

Figure 2. Map of 28 water systems marked with a yellow pin (Google Earth, 2010).

\subsection{Geographical and Cultural Context}

It is evident in Figure 2 that $\mathrm{EH}$ volunteers have predominantly worked in the western and eastern end of the country. These regions have some of the greatest needs in Panama in terms of basic water supply and sanitation infrastructure. An indigenous group, Ngäbe, inhabits all the communities visited on the western end of the country. The majority of communities visited on the eastern side are occupied by "mestizo" (European ancestry mixed with indigenous group) farmers and cattle ranchers who migrated from the central part of the country within the last 
20-30 years because of land scarcity. There is a great need for water systems on the far eastern end of the country, near the Colombian border, where the indigenous groups Embera, Wunan, and Kuna live. However, the security issues regarding guerrillas and drug trafficking prohibit volunteers from entering the region. The 28 communities assessed in this study are broken down by ethnic group as follows:

- 19 Ngäbe (Guyami)

- 6 mestizo

- 2 Embera

- 1 Kuna (San Blas)

The majority of these communities are only accessible by four-wheel drive vehicles, boats, foot, or a combination of these. The population of these communities ranges from 100 to 1,000 people in each. Although each group has their own language and customs, the majority of community members would be considered as semi-subsistence farmers because they supplement the food grown on their farms with the income generated from the sale of agricultural products, seasonal migratory work, occasional work as day laborers, and temporary conditional cash transfers through a program known as the Red de Oportunidades.

\subsection{Field Procedure}

A copy of the solicitation form for funding was available for most communities, which provided some background information regarding work completed by the volunteer and the key community members that worked closely with them. This information helped the author prepare for each community visit. Since cellular phones did not become common in these areas until 2008 or 2009, almost none of these forms provided phone numbers to allow contact of communities before the visit. Unless there was a volunteer living in the community or one nearby, the author thus arrived unannounced.

Upon arriving in the communities, the author introduced himself in a friendly manner to the community members he encountered, and explained that the Peace Corps would like to know how the water system is functioning. The trust of the community members was earned by engaging in discussions about the weather, crop production and family life or reminiscing about the PCV that previously lived in the community. During these conversations, questions regarding the quality of the water supply service and the maintenance procedure were 
mentioned but the responses were never written down in front of them. Then the author asked how he would be able to find people with intimate knowledge of the water system such as the names mentioned in the volunteer report or current members of the water committee.

Since the author had lived and worked amongst the Ngäbe people for more than three years, he had an intimate knowledge of their culture. This allowed him to communicate effectively in the 19 Ngäbe communities visited. When the author introduced himself and explained the purpose of the visit in their native tongue Ngabere, it was apparent that most were pleasantly surprised and felt more relaxed, especially the women and elders with limited Spanish. For the Kuna and Embera communities, abiding by the local custom, the author first spoke with the village chief to receive their permission to enter their land. Since the "mestizo" culture is known to be most open to the outsiders, it was much easier to relate with them.

Fortunately, the community members were typically welcoming of the author's presence. Many offered drinks, food and even a place to stay overnight in case the last transportation of the day had already left. In most cases, at least one member of the water committee agreed to be the guide for the transect walk across the water system. This was impressive especially since there was no advance notice of the visit and some of the sources were located up to $8 \mathrm{~km}$ away from the community. In addition to being able to inspect each component of the water system, these transect walks provided a valuable opportunity to engage in a dialogue with these dedicated members about their experiences, opinions and challenges regarding the management of their water system.

After the transect walks, the water committees were asked if they possessed any documents regarding their water systems. The existence and quality of documents such as ledgers, receipts, balance sheets, meeting minutes, attendance lists, and operator's manual served as indicators to gauge the financial, managerial and administrative capacities of the water committees. Additionally, observing these documents helped to triangulate the statements made by community members regarding information such as willingness to pay. Unfortunately, there were many cases when the president, secretary or treasurer that holds on to these documents was not available during the visit.

Time spent in each community ranged from several hours to two full days, depending on the size of the community and water system. A substantial amount of time was spent drinking coffee 
and discussing the latest news at people's homes, which helped to avoid the rigid and prescriptive "a man with the clipboard" approach. Communities with problems in the infrastructure of the water system typically solicited additional technical help or donations in materials. In order to avoid any unrealistic expectations, it was reiterated that the information from this visit will be passed to the PC office and Waterlines, but cannot guarantee immediate assistance. If they were interested in receiving additional help, they would have to follow the PC standard procedure and directly solicit for help through the PC regional coordinator. Imposing this extra step to receive assistance usually helps to curtail demands of individuals who seek to receive handouts every time an outsider steps into their community.

\subsection{Results and Discussion}

Although it would be ideal to have the water committee and users rank themselves according to the indicators established in Chapter 3, the following circumstances forced the author to rank the water systems based on his own observations. 1) It was difficult to organize all the water committee members and users, especially without any advanced notice. 2) The availability of the community members with intimate knowledge of the system during the visit was not guaranteed. 3) There was limited time in each community.

However, these indicators still served as a guideline and checklist for what needs to be observed and discussed during each community visit. The scores are supported by a descriptive report prepared for each community. Based on the assessment of each system, a set of recommendations was also given for each community.

\subsubsection{Water System Profile}

Below are the general characteristics of the 28 water systems evaluated for this study. More details regarding the history of each system can be found in Appendix D:

- 27 gravity flow water systems and one solar pump system (the solar pump had already ceased to function).

- PCVs constructed 17 brand new systems and rehabilitated or expanded 11 systems.

- Number of houses connected to the system ranged from five to 400.

- The age of the systems ranged from less than a year to more than 30 years.

- All the PC interventions happened within the last 8 years.

- The average age of the system constructed by a volunteer was 4 years old. 
The following sections present the scores from the 28 community visits. For each indicator, a graph with the score of each community and a table with the distribution of scores were prepared. The score " 0 " in the graphs implies that there is no data available because it is either not applicable or the data could not be collected for that particular community. In order to account for any missing data, the percentages of distribution are calculated based on the communities with available data. In the distribution table, the range of scores were divided in three categories with 1) " 4 " to " 5 " indicating ideal conditions, 2) " 2.5 to 3.5 " indicating deteriorating conditions, and 3) " 1 " to " 2 " indicating unacceptable conditions. The scores do not necessary represent the quality of past $\mathrm{EH}$ projects, because in certain cases the volunteer only worked on a small section of the water system. When looking at the results, it is important to keep in mind that the wide range of community size, and the scale and age of the water system might affect the scores.

\subsubsection{Watershed}

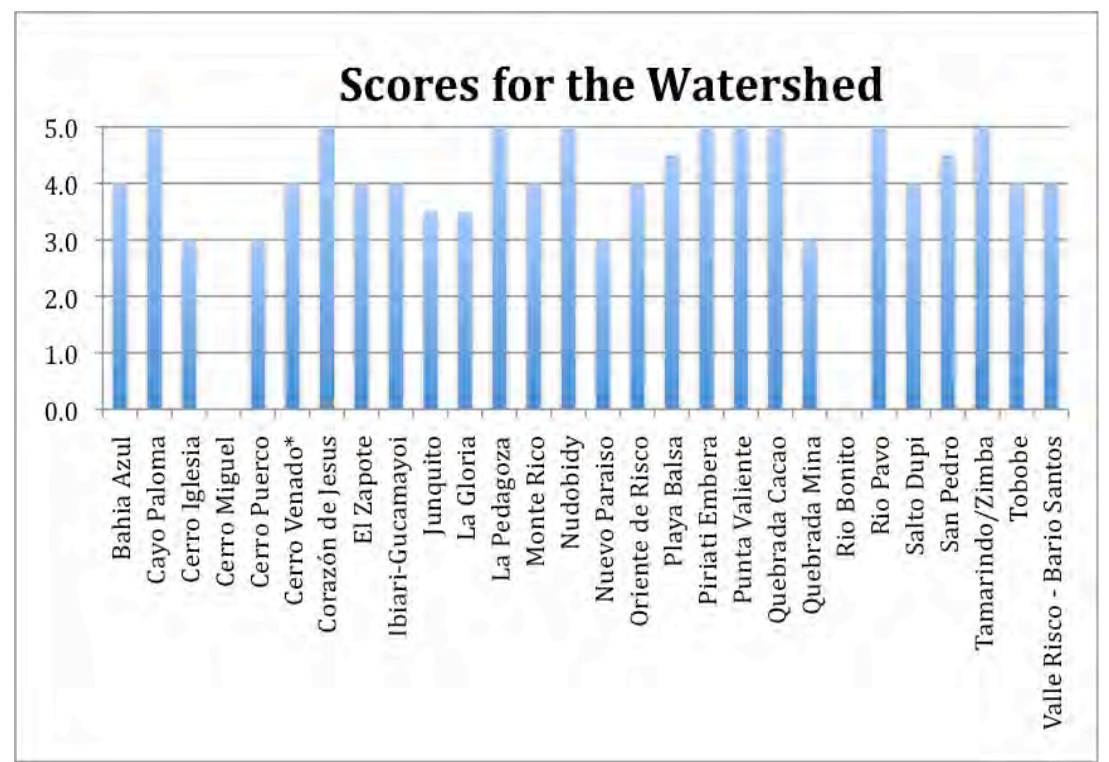

Distribution of Scores for the Watershed

\begin{tabular}{|l|r|}
\hline Score Range & Distribution \\
\hline 4 to 5 & $76.9 \%$ \\
\hline 2.5 to 3.5 & $23.1 \%$ \\
\hline 1 to 2 & $0.0 \%$ \\
\hline $\begin{array}{l}\text { Percentage based on } 26 \\
\text { communities. }\end{array}$ \\
\hline
\end{tabular}

\section{Figure 3. Results for the watershed indicator.}

The scores for watersheds were determined based on the tree coverage around the source, presence of contaminants or their sources, such as latrines, agrochemicals, and domestic animals, and existence of a written contract with the owner. Although a high score does not necessarily mean that source provides acceptable quality and quantity of water, it serves as an indicator to the community initiative to protect their source. 
The MINSA regulation states that there must be a written contract with the owner before starting any water supply projects, but only nine out of 28 communities possessed such documents. Some communities with low scores expressed interest in receiving additional help in the negotiation process with the landowner. Figures 4(a) and (b) demonstrate examples of well-protected and degraded watersheds, respectively.

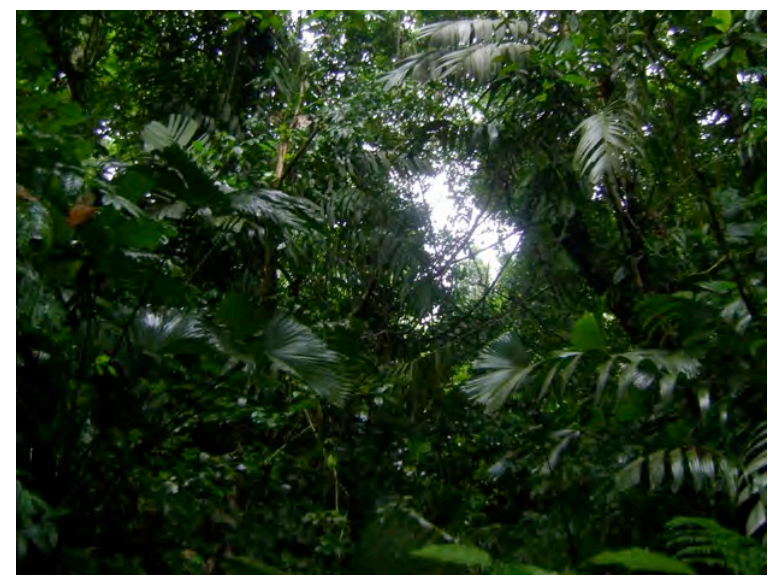

(a)

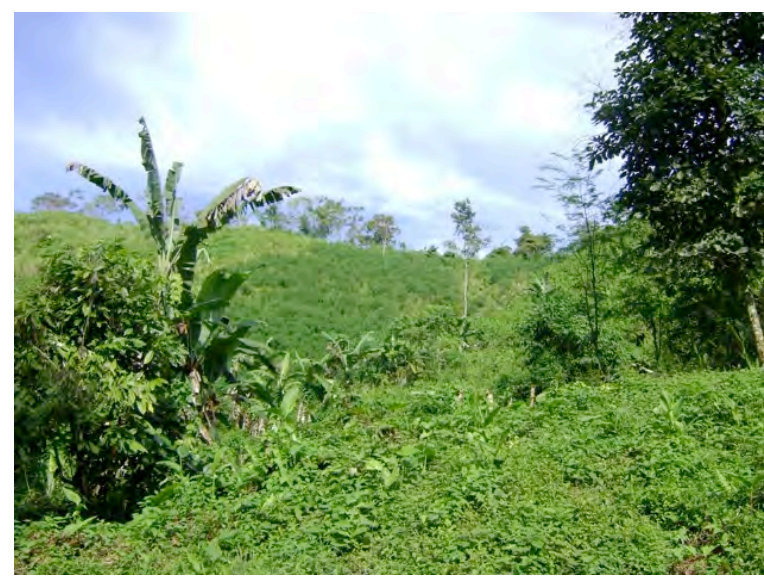

(b)

Figure 4. Photos of the watershed. (a) - Example of a well-protected watershed taken in Bahia Azul, Comarca Ngäbe-Buglé (CNB) Nukribo. (b) - Land surrounding the source has been cleared off for agriculture use in Cerro Puerco, CNB Kadri region.

\subsubsection{Source Capture}

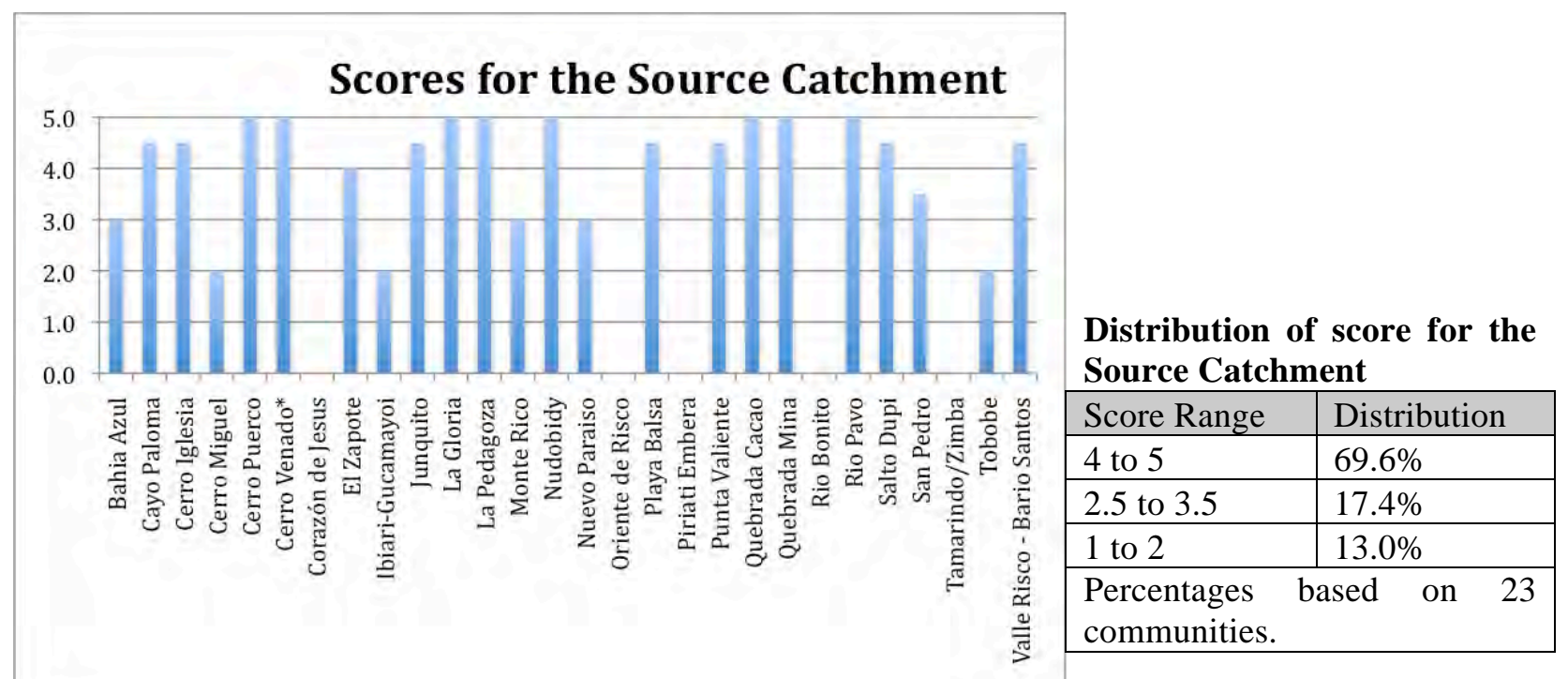

Figure 5. Results from the source catchment indicator.

The source capture or spring box was evaluated based on how well the spring source was protected from the surface water runoff and its effectiveness in capturing the water necessary to 
meet the community demand. The communities without ideal source catchment such as Tobobe and Ibiari-Gucamayo, had problems with the water carving out a new path and leaking from the bottom of the spring box as demonstrated in Figures 6(a) and (b). In these cases, the water committee members usually expressed that they do not have the technical skills to repair the leaks on their own and would like to receive additional assistance from the Peace Corps. Others also solicited training to build a spring box so that masons in their communities can repair or build new ones on their own.

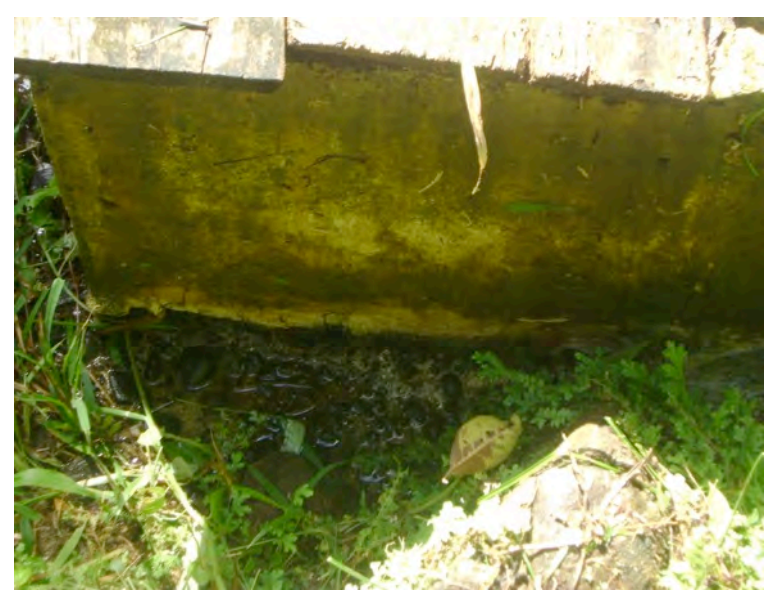

(a)

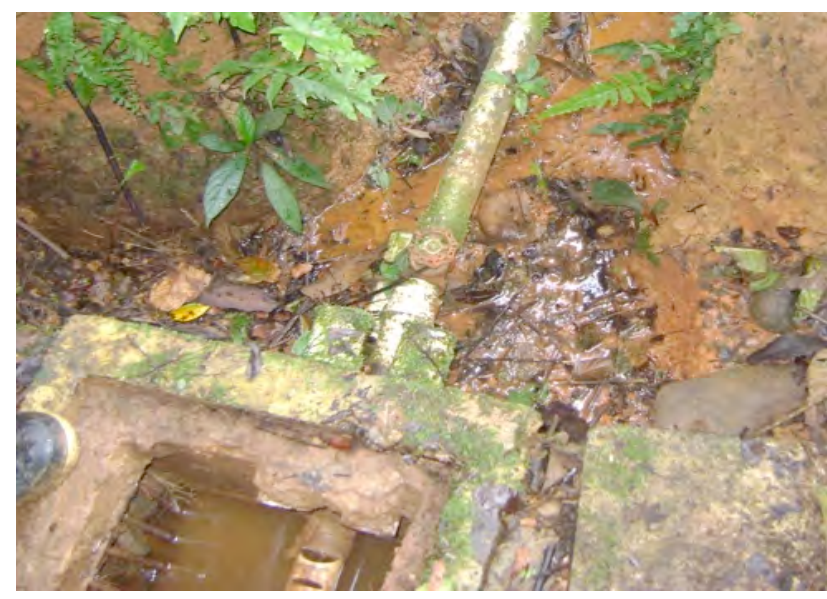

(b)

Figure 6. $\quad$ Spring boxes with major water loss. (a) - Photo taken in Tobobe, CNB Ñukribo. (b) Photo taken in Oriente de Risco, Bocas del Toro.

In general, there were two types of spring box design. The first type resembles a typical spring box design with a larger collection box as shown in Figure 7 (a). The second type is an original design invented by a mason Nicolas Arcia who has worked closely with Waterlines for many years. As shown in Figure 7 (b), the outlet and overflow pipes are installed as low as possible. Nicolas believes that when water accumulates within the catchment area, it will attempt to find a path of least resistance by carving out a new path below the current catchment area. This design is also more effective in protecting and capturing water from the sources with larger catchment area. Although most spring boxes built by Nicolas were less than five years old, none of them had a problem with water leaking from the bottom. 


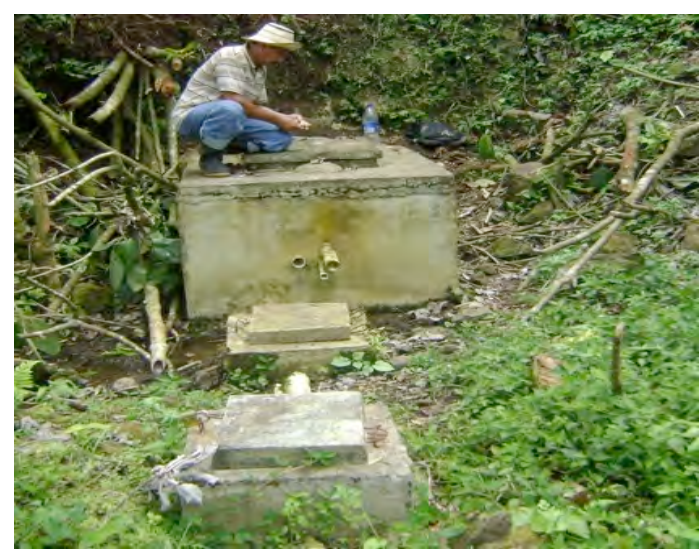

(a)

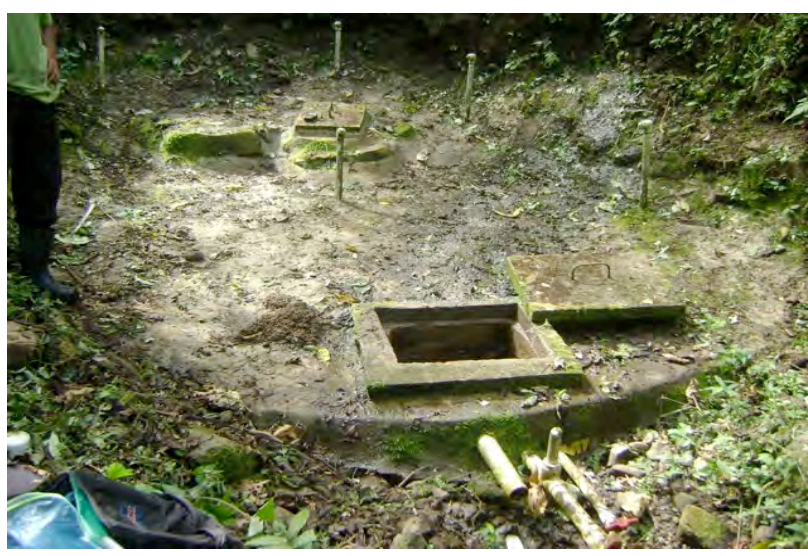

(b)

Figure $7 \quad$ Two types of spring boxes. (a) - Traditional design with a taller collection box (photo taken in San Pedro, Cocle). (b) - Nicolas Arcia's original design with much lower placement of outlet and overflow pipes. (Photo taken in Quebrada Cacao, Bocas del Toro).

The three communities that used dams to capture stream or small rivers source were not included in this particular ranking. For future assessments, there should be another ranking system for the intake dams, as the quality of the infrastructure varied significantly between the three dams.

\subsubsection{Transmission Line}

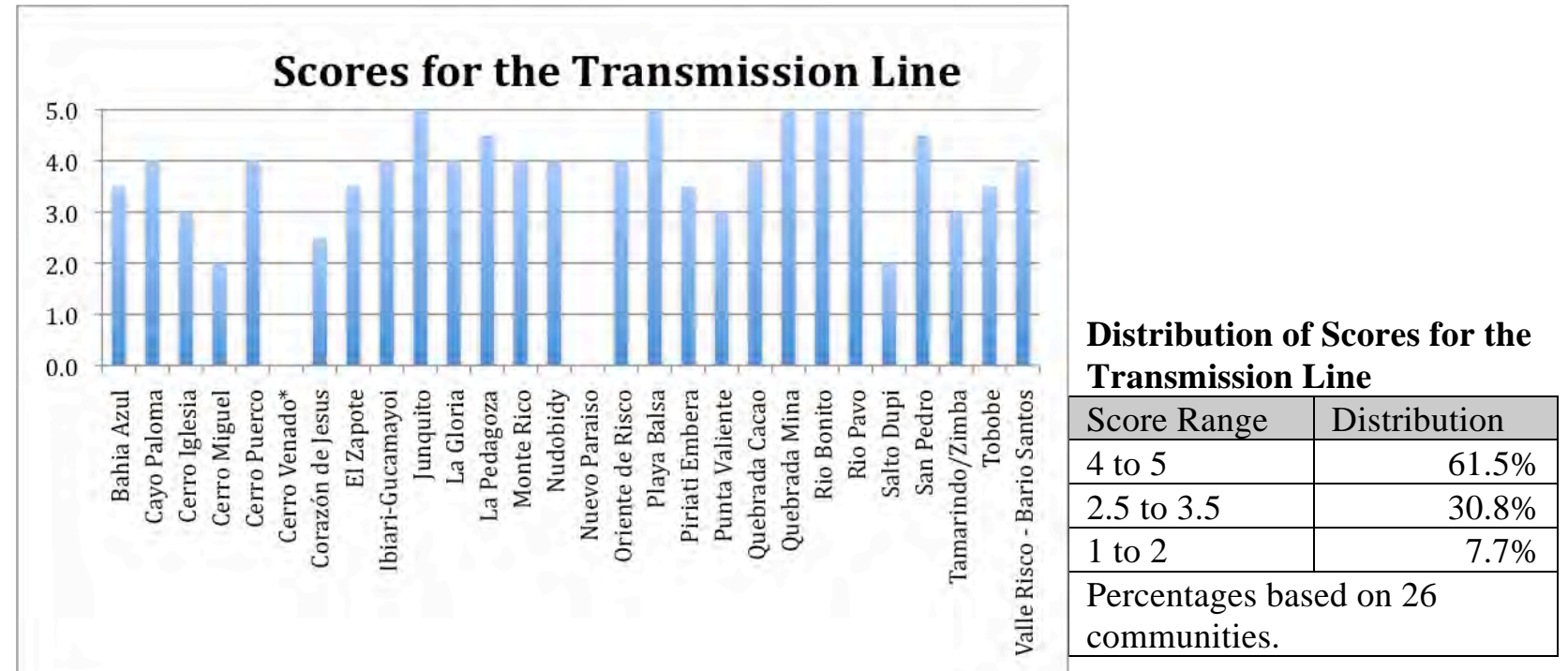

Figure 8. Results for the transmission line.

The transmission line was evaluated based on the tube exposure, leakage, damage, and proper installment of key components such as air releases valves, bridge-crossings, and break-pressure tanks. The scores recorded in Figure 8 do not necessarily reflect the construction quality or community capacity or will to replace damages in the line. In some communities such as Playa 
Balsa and J unquito, where the source is located near the storage tank, the transmission line is only a few meters long. This makes them less vulnerable to damage and much easier to maintain, compared to other longer lines.

Depending on the terrain, it may only take a few years for erosion to expose buried tubes as shown in Figure 9 (a). In other cases, the tubes were never buried because the line crossed a terrain with many roots and rocks or there was a lack of oversight during the construction phase (Figure 9 (b)). The air release valves are fairly expensive and hard to find in Panama, and therefore, many communities are forced to puncture a hole through the tube to release the air for air blockage. A piece of wooden stick is often used to cover the holes as shown in Figure 9 (c), but the water still leaks out and the stick decomposes quickly. Seeking to find a better solution for the air blockage, a volunteer designed an air release valve that can be fabricated with readily available and less expensive materials. However, many of these valves were found to be leaking as shown in Figure 9 (d).

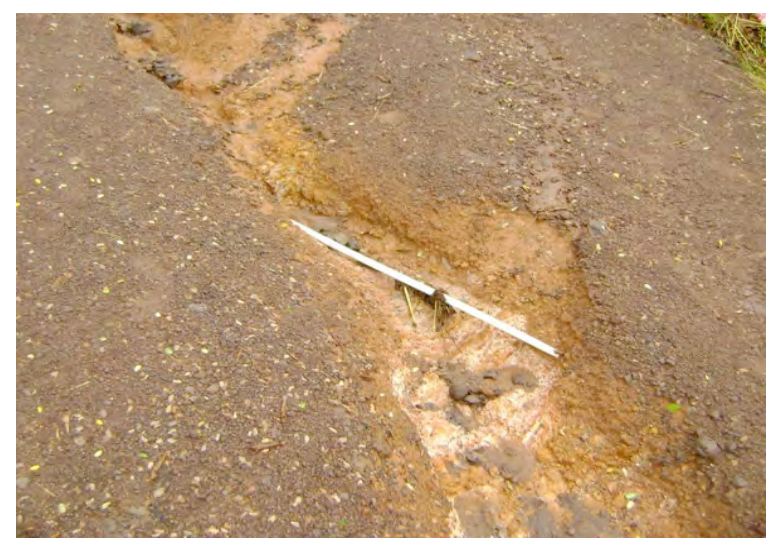

(a)

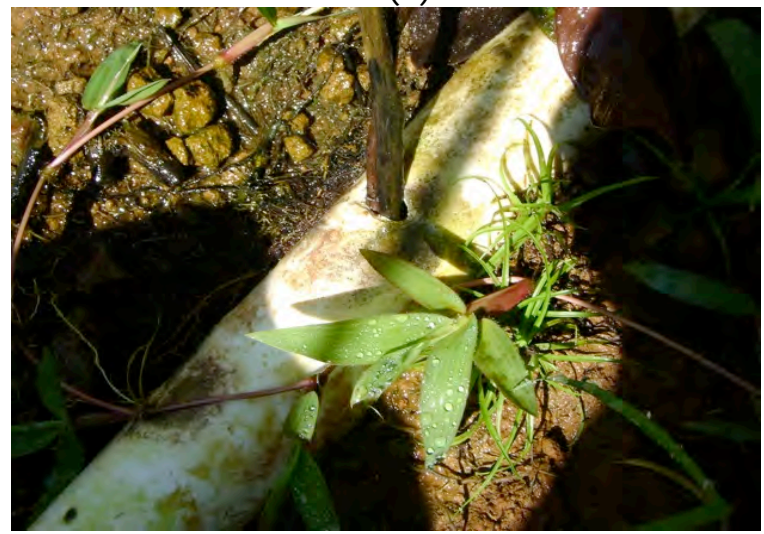

(c)

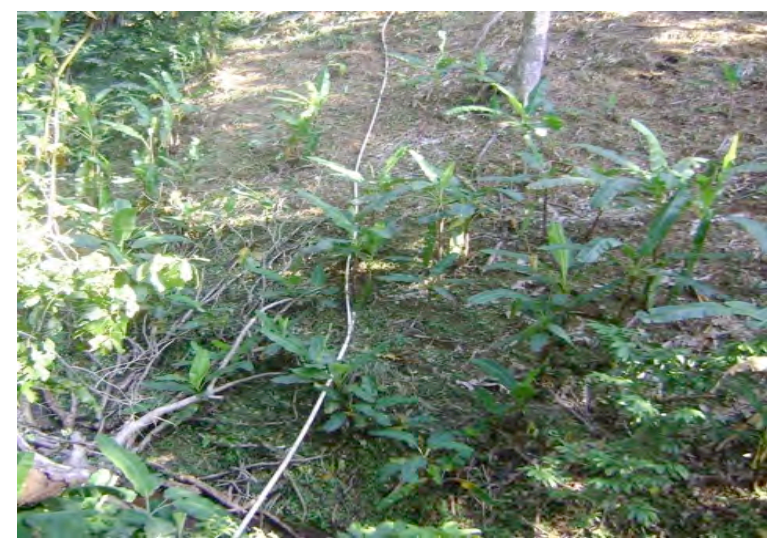

(b)

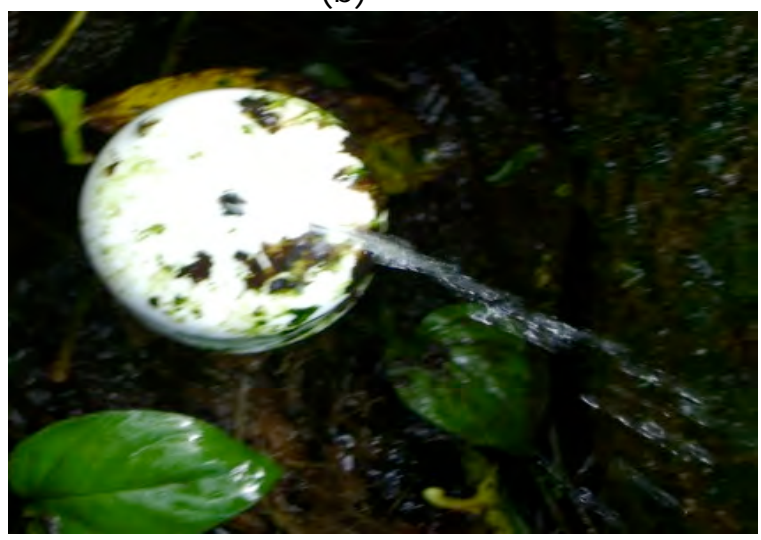

(d)

Figure 9. $\quad$ Common problems with the transmission line. (a) - Tube exposed by erosion in Cerro Puerco, CNB Kadri. (b) - Tubes that were never buried in Punta Valiente, CNB Ñukribo. (c) - Hole covered for air release covered with a piece of wooden stick in Salto Dupi, CNB Nedrini. (d) Homemade air release valves that was found to be leaking in Cerro Puerco, CNB Kadri. 
Another common problem with the transmission line is that the damages are repaired inadequately (Figure 10 (a)). Many plumbers prepare the female end of the PVC tube by heating it directly with fire. The joints made with this method are much weaker and generally do not make a tight seal (Figure 10 (b)). Additionally, some communities repair damages without using PVC glue or they do not know that once the can of PVC glue has been opened, the quality of glue starts to deteriorate. Finally, in many cases, the damages are much more difficult to detect and repair when the lines pass through terrain with thick vegetation.

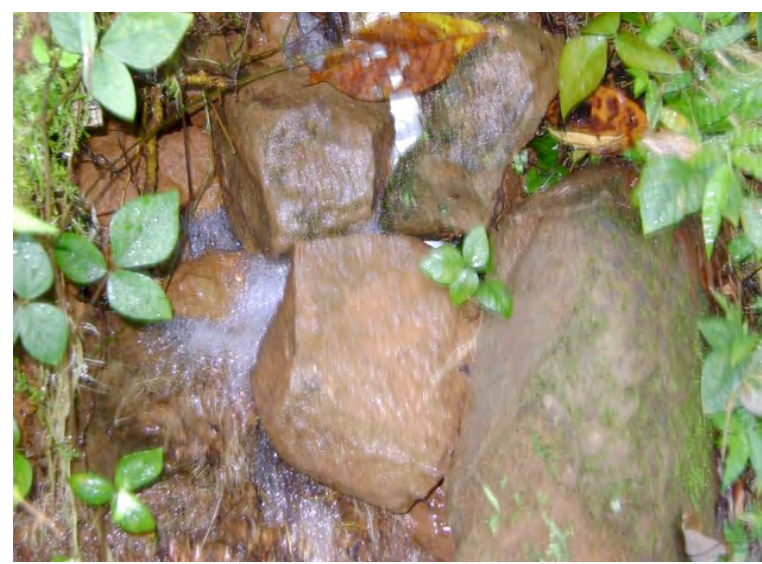

(a)

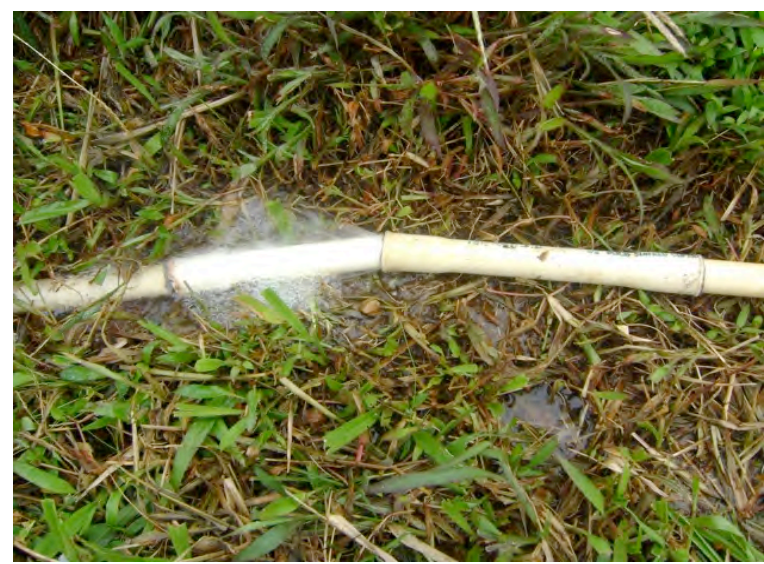

(b)

Figure 10. Problems with poor repair job of transmission lines. (a) - Rocks used to weigh down poorly made joints in Salto Dupi, CNB Nedrini. (b) - Joints fabricated over direct fire and connected without any PVC glue in Playa Balsa, CNB Ñukribo.

\subsubsection{Storage Tank}

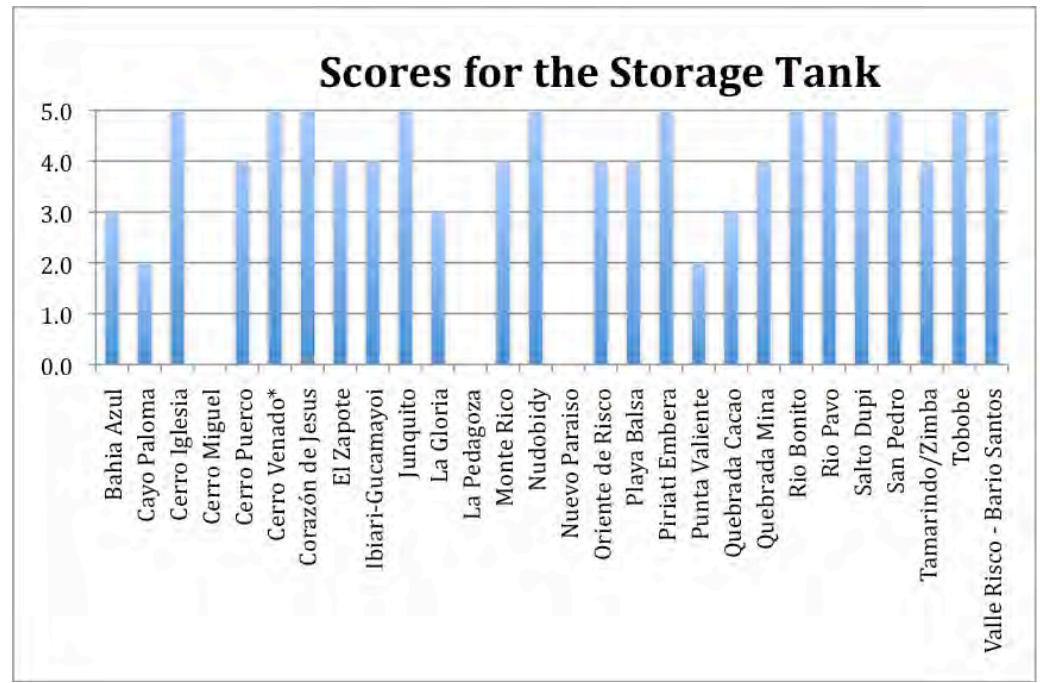

Distribution of Scores for the Storage Tank

\begin{tabular}{|l|r|}
\hline Score Range & Distribution \\
\hline 4 to 5 & $80.0 \%$ \\
\hline 2.5 to 3.5 & $12.0 \%$ \\
\hline 1 to 2 & $8.0 \%$ \\
\hline $\begin{array}{l}\text { Percentages based on } 25 \\
\text { communities. }\end{array}$ \\
\hline
\end{tabular}

Figure 11. Results for storage tank assessment.

The most common problem observed for the storage tanks is leaks forming on the corners (Figure 12 (a)). The corners of square tanks are more susceptible to leaks since they are subject 
to the highest hydraulic pressure. Although cylindrical-shaped tanks are preferable, none of the communities had concrete cylindrical tanks. There were some that had factory-made plastic cylindrical tanks. Leaks were also observed on the sections of the tank where the outlet and cleanout pipes are inserted (Figure 12 (b)).

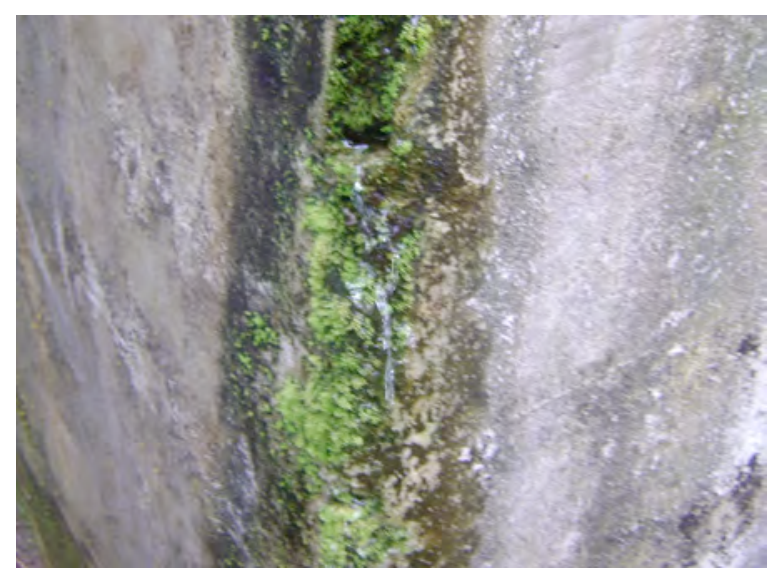

(a)

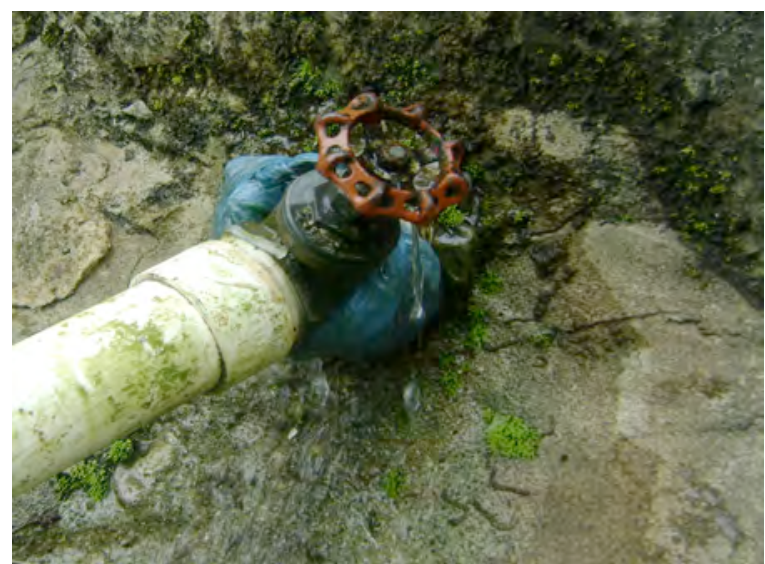

(b)

Figure 12. Common problems with storage tanks. (a) - Corners of the storage tank leaking in Cayo Paloma, CNB Ñukribo. (b) - Outlet pipe connection leaking in Cayo Paloma, CNB Ñukribo.

The author intended to gauge the cleaning schedule by asking multiple questions to multiple people and triangulating their response with the observation of the state of the area surrounding and inside the tank. For example, the response to when was the last time the tank was cleaned, can be validated by observing the height of grass around the tank

The project solicitation form completed by the PCV usually specified the source output, tank size, and population size. Even with the population growth, the forms indicated that the tank size is sufficient. This information was triangulated in the field by asking if the tanks would still overflow in the morning, even though there is a shortage of water during the day. A typical answer was that when there is a shortage, the storage tank does not fill up. Therefore, all of the storage tanks were determined to have sufficient storage capacity, and the shortages are due to lack of source output and/ or damages in the system. 


\subsubsection{Distribution System}

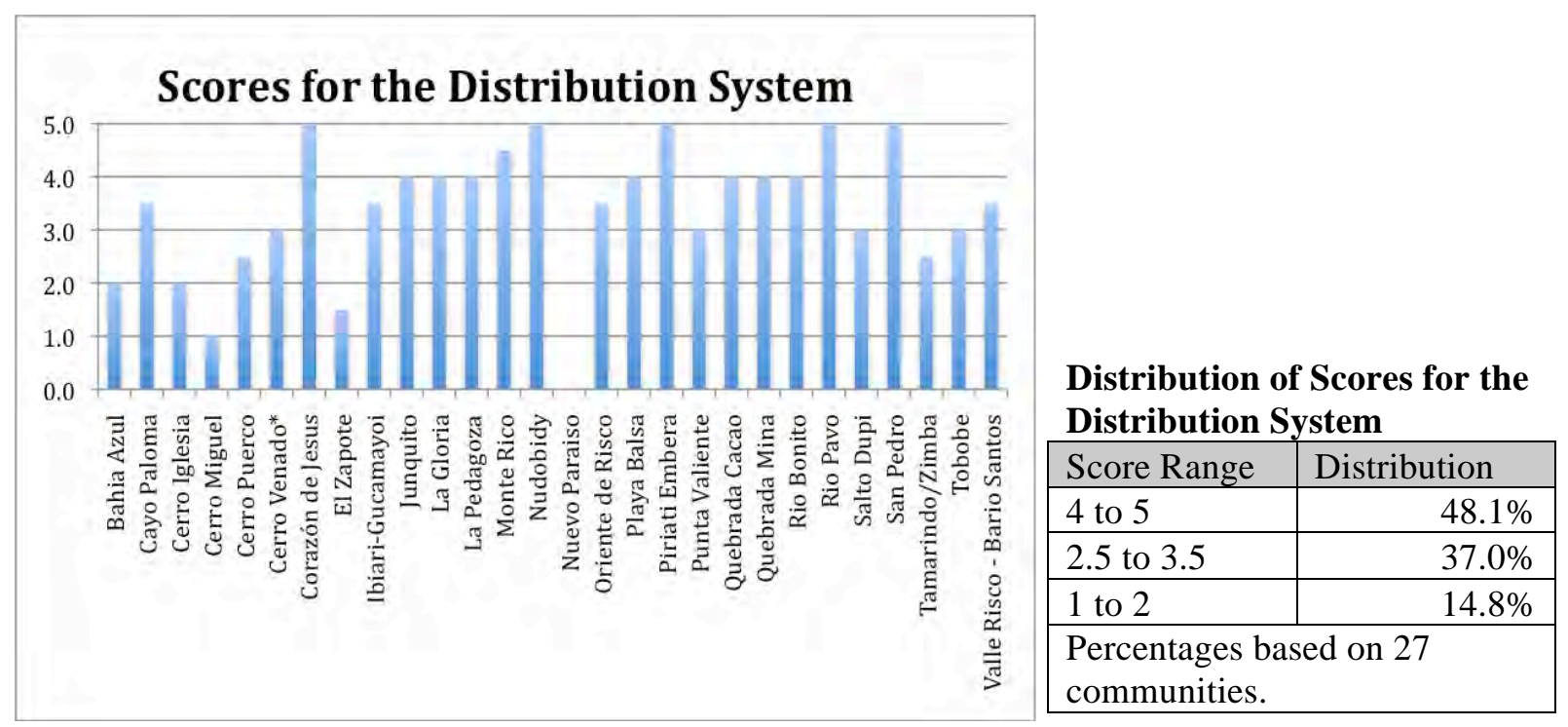

Figure 13. Results for the distribution system.

Many of the communities such as Valle Risco and Cerro Puerco with lower scores for the distribution system typically have major elevation differences between the houses. The elevation difference and distance from the tank creates inequity in pressure and flow amongst the houses, especially when the tube sizes were not designed properly. One indicator of pressure inequity are the houses that have lowered the tap stand as low as possible in an attempt to increase the pressure. For example, in Figure 14, the owner had to excavate in order to place a bucket in front of the tap. Speaking with users living in various parts of town also helped to triangulate the claims made by the water committee members.

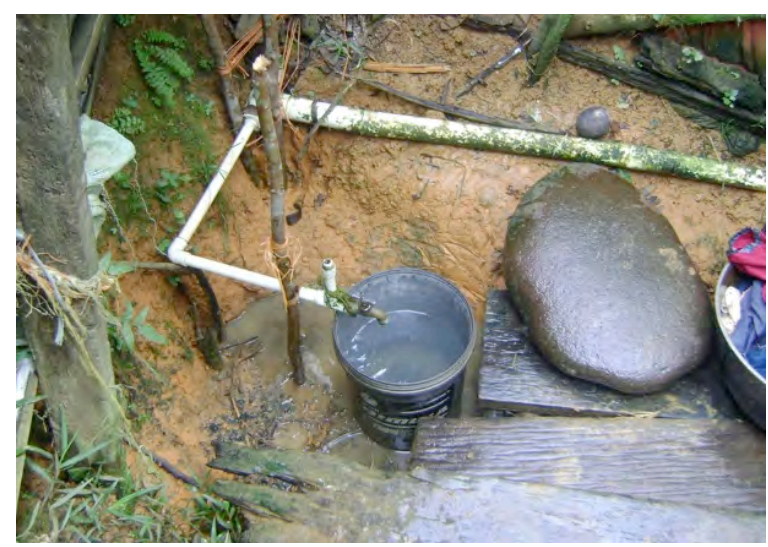

Figure 14. Tap stand lowered to the ground level due to lack of pressure (Photo taken in Oriente de Risco, Bocas del Toro). 
Similar to the problems observed in the transmission line, the communities with low scores such as Cerro Iglesia and Salto Dupi, did not repair the damages or repaired them poorly. When there are insufficient number of control valves installed throughout the distribution system, the maintenance becomes more time consuming and inconvenient for the users. The distribution systems extended on ad hoc bases without any master design seemed to have fewer control valves.

In many communities, the individual lines connecting the houses to the main line and the taps are considered as private property, unlike the rest of water system, which is considered to be communal property. Hence, if there are ever damages in the individual lines and household taps, each owner is responsible for repairing them. Communities such as Tamarindo/Zimba and Bahia Azul, lack the mechanism to enforce a regulation stating that individual households must repair the damages immediately. Water committee members frequently expressed difficulties with convincing people to follow the regulation. If they take a more authoritative stance, they risk being subject to criticism by the rest of community members. It was also observed that the houses with excessive pressure tend to have more leaky taps, but since they are the last ones in the community to suffer from water shortages, they may have the least incentive to repair the damages.

Another limitation to this methodology is that many leaks in the distribution system are not apparent during the day. When all the taps are closed at night and the storage tank is allowed to fill up, the pressure builds up throughout the distribution system and results in increased water loss through poorly made joints and minor damages. As a result, the tanks are not able to fill up at night. Unless one of the water committee recognizes this and points it out to the investigator, it would be difficult to detect this problem. 


\subsubsection{System Reliability}

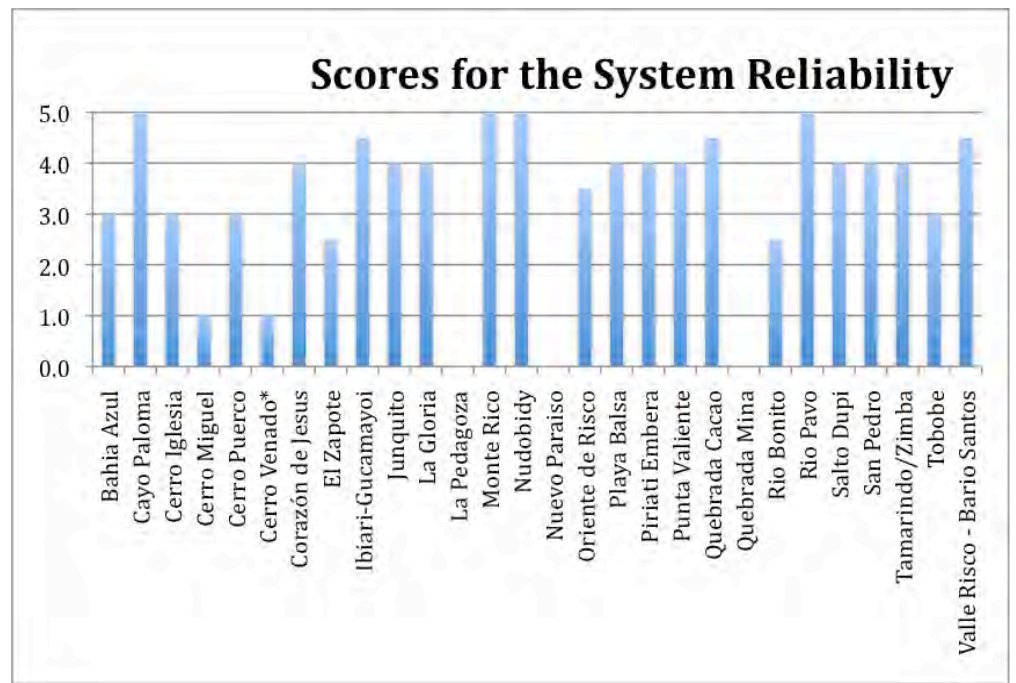

Distribution of Scores for the System Reliability

Figure 15. Results for the system reliability.

\begin{tabular}{|l|r|}
\hline Score Range & Distribution \\
\hline 4 to 5 & $64.0 \%$ \\
\hline 2.5 to 3.5 & $28.0 \%$ \\
\hline 1 to 2 & $8.0 \%$ \\
\hline $\begin{array}{l}\text { Percentages based on } 25 \\
\text { communities. }\end{array}$ \\
\hline
\end{tabular}

The system reliability was determined by triangulating responses of various water committee members and users regarding the availability of water throughout the years. As illustrated by Figure 15, there were only four communities where all of the users had enough water throughout the year. This means that communities that have the right combination of a year round reliable water source and well-functioning infrastructure were very rare in this sample.

In most regions of Panama, the dry season typically lasts from the end of December to the end of March. Many communities expressed concern about how the source output diminishes significantly towards the end of the dry season in February or March. In the Comarca NgäbeBuglé (CNB) Nukribo region and Bocas del Toro province where there is no prolonged dry season, many residents complained about the diminished source output even after only two or three weeks without rain.

However, not all water shortages are due to insufficient source output. In many communities, the physical state of the infrastructure is also responsible for the unreliable service. For example, in the three communities Bahia Azul, Corazon de J esus and Piriati Embera, which use stream sources with more than sufficient flow to meet the community demand, the supply is limited by the system capacity. All three communities experienced some problems with shortages and intermittent services because of damages and leaks. 
In order to investigate the relationship between the physical state of the infrastructure and system reliability, a scatter plot was prepared with a linear regression analysis. The scores for the infrastructure were calculated by taking the average of the source catchment, transmission lines, storage tank and distribution system. The infrastructure was designated as an independent variable (x-axis) and the system reliability was designated as a dependent variable (y-axis).

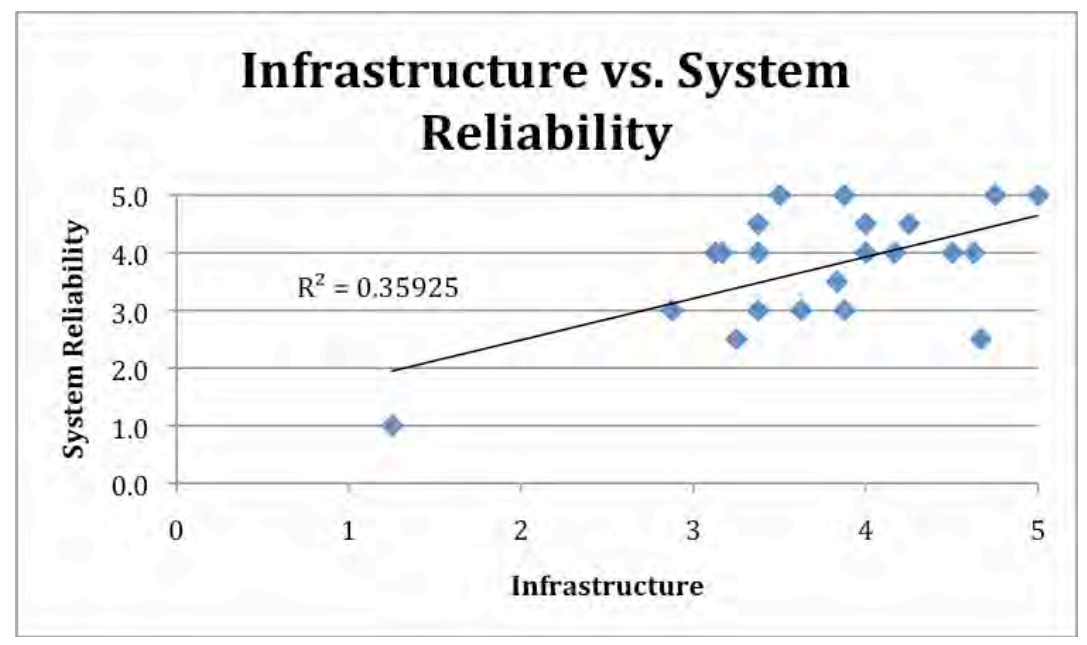

Figure 16. Linear regression analysis between the infrastructure and system reliability.

Figure 16 indicates that there is little or moderate correlation between the state of infrastructure and system reliability. However, the result from this analysis is not conclusive for various reasons: 1) Since the score of infrastructure was determined by taking the average score of source catchment, transmission lines, storage tank and distribution system, these four components are weighted the same. In reality, the weight of each component to estimate the overall state of the infrastructure would vary significantly depending on the scale of each water system. 2) The score of each component represents factors such as protection from runoff, tube exposure, cleaning schedule, and existence of control valves, which do not directly affect the water quantity. 3) 24 communities with data on system reliability may not be a sufficient sample size. 


\subsubsection{Willingness to Pay}

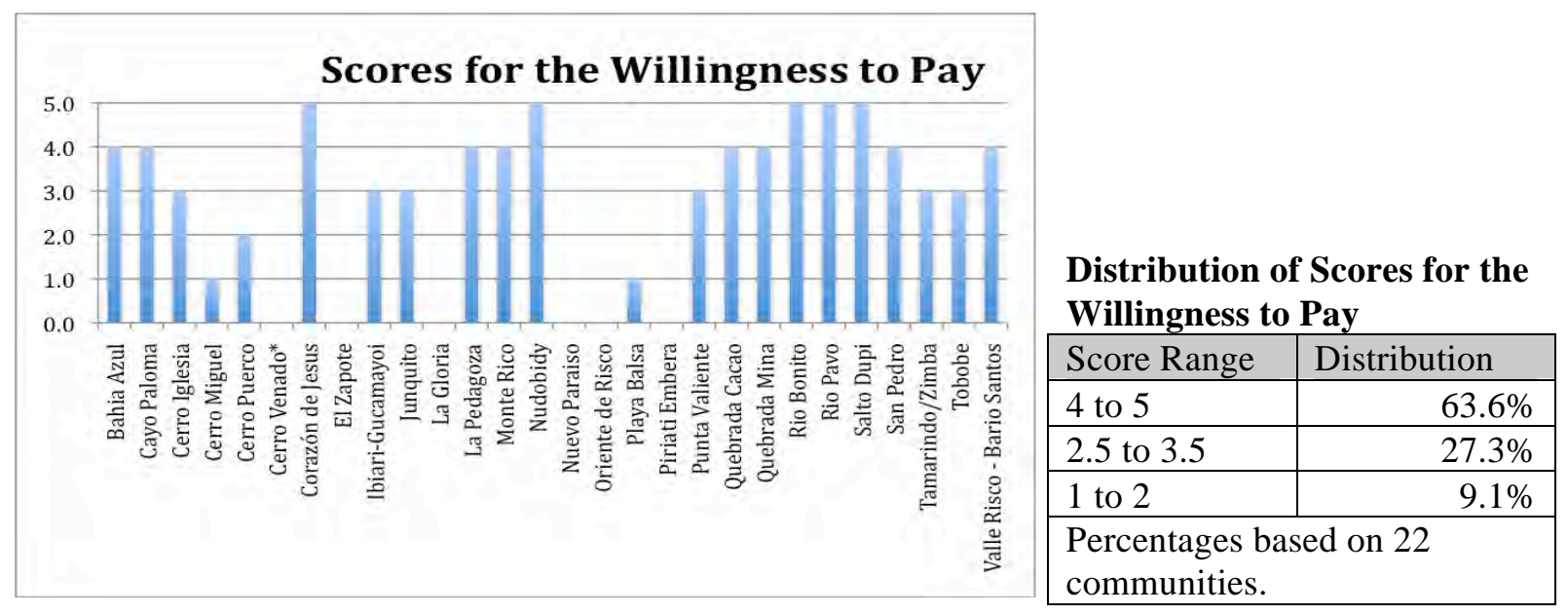

Figure 17. Results for the willingness to pay.

The score for willingness to pay was determined by observing the ledger or other accounting methods used to keep track of payments for the year 2009. When such a document was available, the author asked the treasurer or president for permission to take a photo of it (example show in Figure 18). The photo of the ledger was used to count the number of monthly quotas collected and to derive the percentages of payments collected for the year 2009. Although it would be preferable to work together with the water committee members to calculate the collection rate, discussing such sensitive issues in detail on the first day of meeting each other was determined to be too imposing.

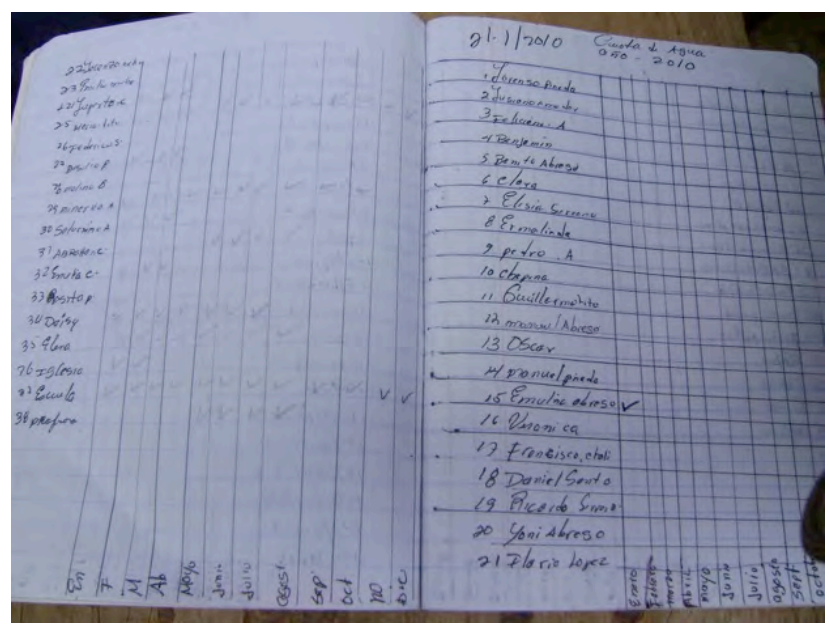

Figure 18. Ledger used to keep track of monthly payments in J unquito, Bocas del Toro.

In most communities, the monthly tariff ranged between $\$ 0.25$ and $\$ 0.75$. Although the sample size of mestizo communities was much smaller, their monthly tariffs were typically found to be 
much higher ranging between $\$ 1.50$ and $\$ 2.50$. This study did not include the level of income for each community, but it is generally assumed that "mestizo" communities are much better off than indigenous communities. Hence, this observation coincides with Schweitzer's (2009) conclusion that community tariffs were established based on the ability to pay and tariffs increase when the level of income increases.

The distribution of scores may be skewed because the communities with a better payment record and more organized ledger seemed to be more eager to demonstrate their documents. These communities with a good payment record would present the document. There were also cases when the committee seemed reluctant to show their ledger, and one treasurer even admitted that she felt too embarrassed to show it.

Most committees were aware of the MINSA regulation regarding the suspension of services after three consecutive months of payment delinquency, as well as the requirement to pay a fine to resume the service. However, only one community claimed to actually enforce this rule (Nudobidy, Bocas del Toro). Most committee members avoided the personal repercussions that would result from cutting their neighbor's service. Many also claimed that the economic situations of many households prohibit timely payments and they should not be punished for it.

It was interesting to note that even high performing committees typically did not seem to be saving funds for major rehabilitation or expansion. The communities thought that the funds collected are for minor repairs only, and expected outside organizations to bear the cost for major repairs. This observation coincides with the conclusions made by Nkong (2009) in Tanzania. 


\subsubsection{Accounting and Transparency}

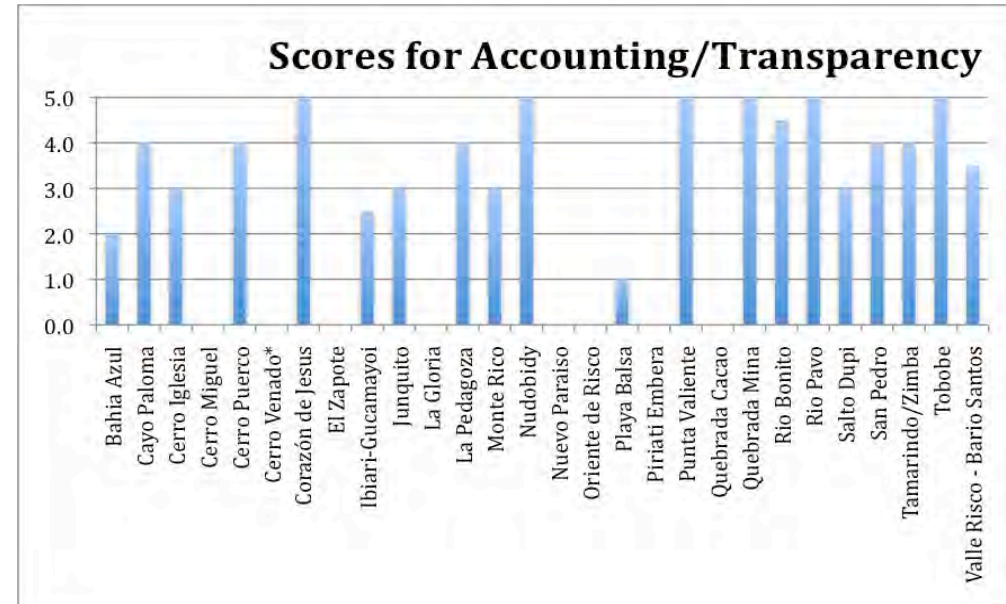

Distribution of Scores for the Accounting/Transparency

\begin{tabular}{|l|r|}
\hline $\begin{array}{l}\text { Score } \\
\text { Range }\end{array}$ & Distribution \\
\hline 4 to 5 & $60.0 \%$ \\
\hline 2.5 to 3.5 & $30.0 \%$ \\
\hline 1 to 2 & $10.0 \%$ \\
\hline $\begin{array}{l}\text { Percentages based on } 20 \\
\text { communities. }\end{array}$ \\
\hline
\end{tabular}

Figure 19. Results for accounting and transparency.

As discussed under willingness to pay, the communities with strong accounting and transparency practices seemed to be more eager to show their documents to the author. As a result, the distribution of scores might be skewed, since it is easier to collect data from communities with good practices. The communities with high scores handed out proof of payment for monthly payments to users (Figure 20 (a)), kept track of all the receipts for purchases (Figure 20 (b)), maintained well-organized ledgers and balance sheets (Figure 20 (c)), and reported to the rest of the community periodically. Many of the communities with higher scores attributed PC or government agencies for teaching them how to perform basic accounting.

Since poor performing communities did not keep receipts and balance sheets, it was difficult to observe misuse of funds. However, in the communities with a low score, many admitted that the previous water committee (never the current one) was accused of misusing pubic funds.

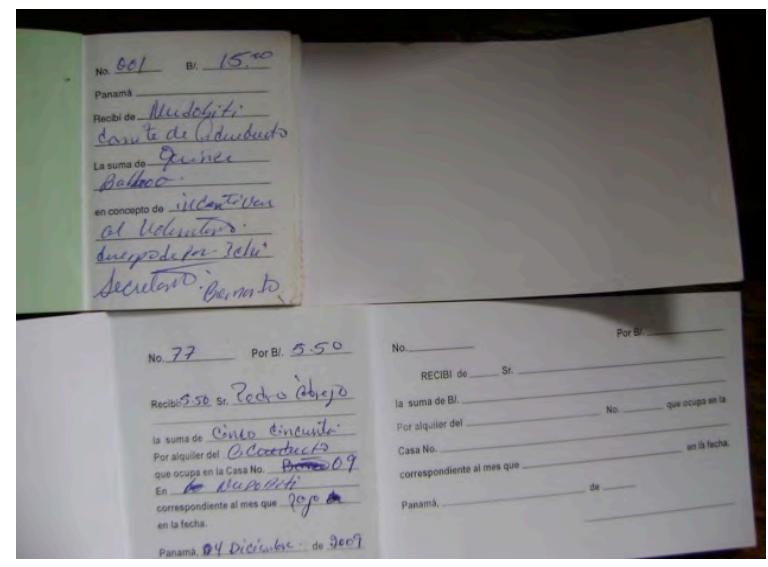

(a)

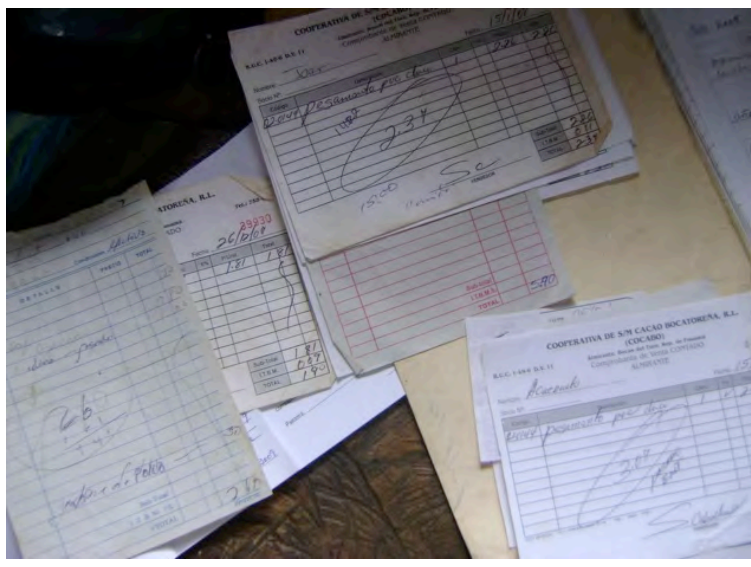

(b) 


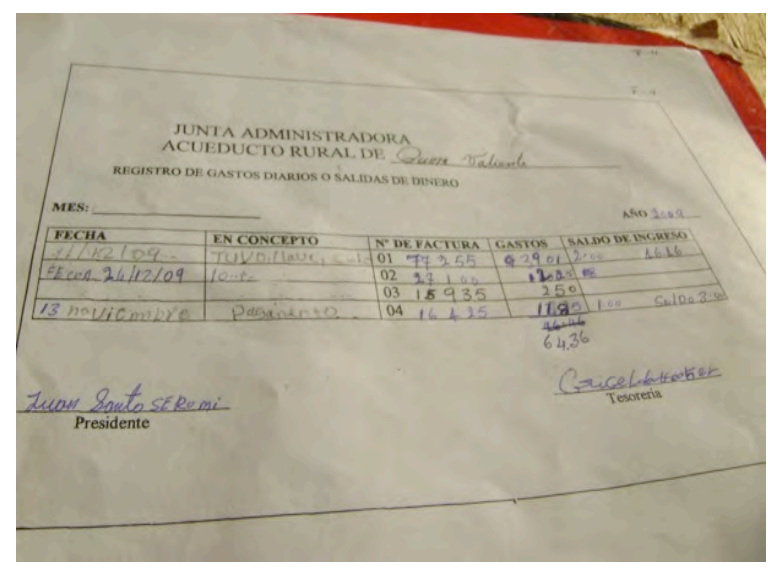

(c)

Figure 20. Examples of good accounting practices. (a) - Proof of payment for monthly tariffs handed out to users in Nudobidy, Bocas del Toro. (b) - Receipts are well organized in Nudobidy, Bocas del Toro. (c) - The official JAAR balance sheet that was provided by MINSA (Punta Valiente, CNB Nukribo).

\subsubsection{Maintenance}

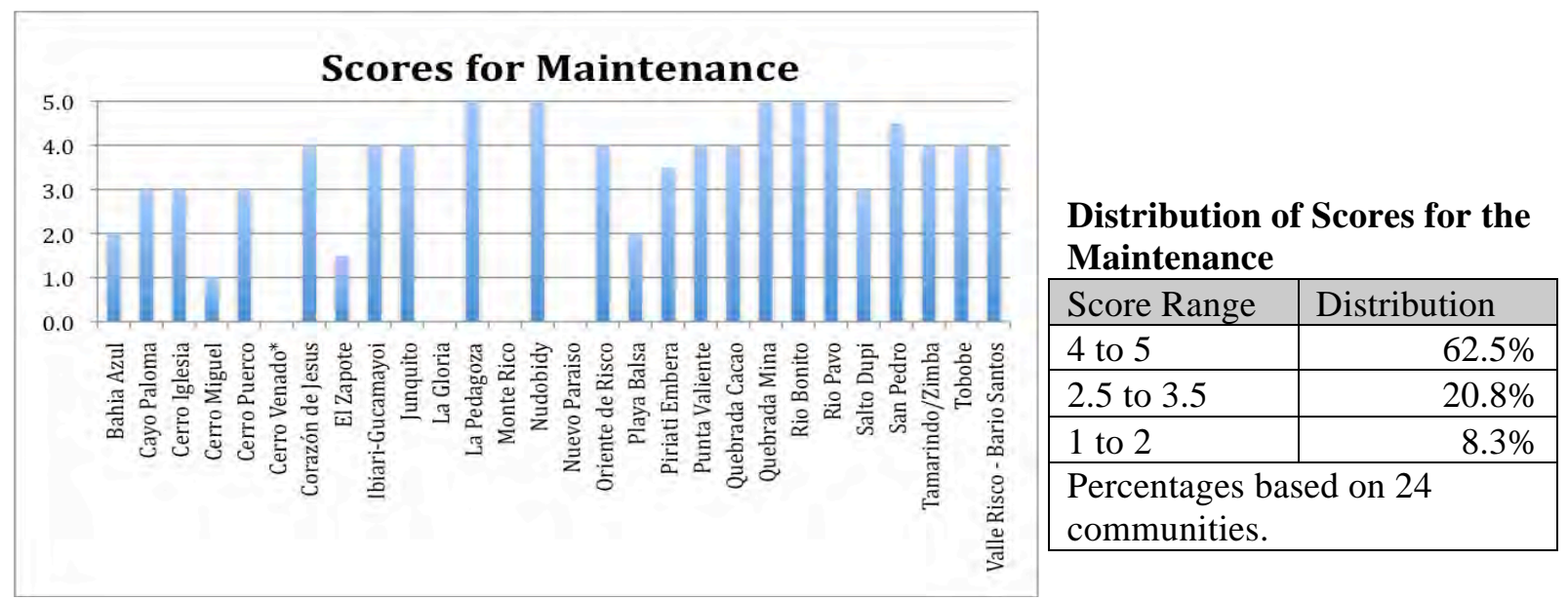

Figure 21. Results for the maintenance.

The level of maintenance was estimated by asking questions such as; who is the person responsible for repairing the damages, when was the last time that the maintenance work was carried out, and how much money has been spent on materials. Their responses were triangulated with the observations made during the transect walk regarding the extent of damages and leaks.

It was apparent that many communities with lower scores had less incentive to repair damages when there was abundance of water. They were more concerned about maintenance during the dry season when the shortages became more prevalent. Many communities were also more 
willing to repair minor damages that were easily accessible, such as the ones located on the main path, but reluctant to repair damages on places such as the top of bridge crossing. However, very few communities demonstrated that they were capable of repairing damaged storage tanks or spring boxes.

It was also noted that the full-time salaried plumbers only existed on the eastern side of the country, in the provinces of Darien and Panama Este. It seems that a culture of paying for the service of a plumber to repair damages does not exist in the western side of the country. The few communities with designated plumbers did not provide them with any compensation.

\subsubsection{Active Water Committee Members}

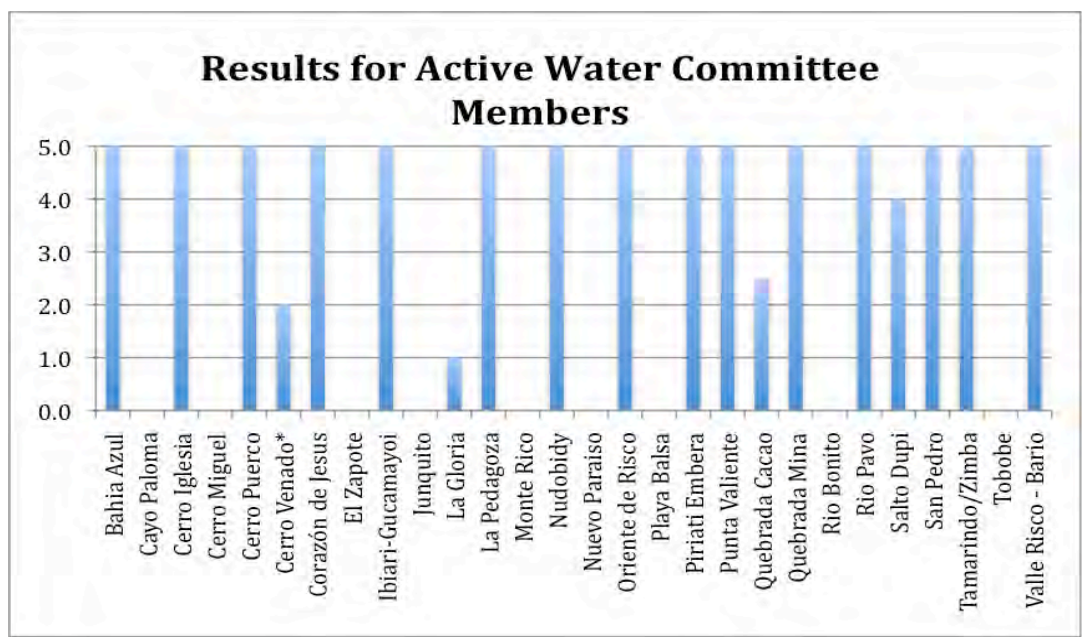

Distribution of Scores for the Active Water Committee Members

\begin{tabular}{|l|r|}
\hline Score Range & Distribution \\
\hline 4 to 5 & $84.2 \%$ \\
\hline 2.5 to 3.5 & $5.3 \%$ \\
\hline 1 to 2 & $10.5 \%$ \\
\hline $\begin{array}{l}\text { Percentages based on } 19 \\
\text { communities. }\end{array}$ \\
\hline
\end{tabular}

Figure 22. Results for the active water committee members.

According to the scoring criteria, the members that participate in the majority of meetings and workdays were considered as active. This information was collected mainly through informal conversations with different committee members and users. In some communities, once the author explained the purpose of the visit to one of the members, the entire committee was able to organize themselves by the end of that day. The graph in Figure 22 indicates that the majority of communities, where the author was able to gauge participation of the individual committee members, received high scores. This may be due to the tendency of communities with dysfunctional committees to intentionally or unintentionally hide the negative aspects of their communities. 


\subsubsection{Distribution of Scores}

It was interesting to note that all ten indicators had a similar distribution of scores. The summary of the score distribution in Table 19 demonstrates that higher scores were always more prevalent. The majority of analysis was qualitative, making it possible that if another investigator carries out the same study, the scores would be much different. However, since the same author collected all the data, the author's personal bias was applied to all the communities.

Table 19.

\begin{tabular}{|c|c|c|c|c|c|c|c|c|c|c|}
\hline \multicolumn{11}{|c|}{ Distribution of Scores for the Ten Indicators (\%) } \\
\hline & $\begin{array}{l}\vec{D} \\
\overline{0} \\
\bar{\omega} \\
\overline{0} \\
\bar{\omega} \\
3\end{array}$ & 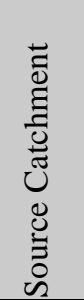 & 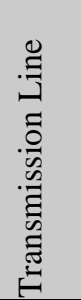 & 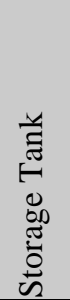 & 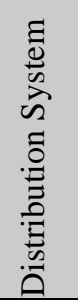 & 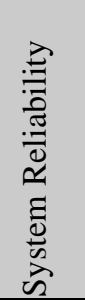 & 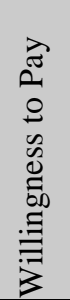 & 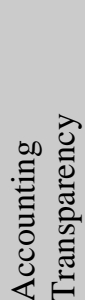 & 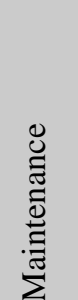 & 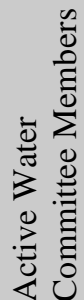 \\
\hline 4 to 5 & 76.9 & 69.6 & 61.5 & 80.0 & 48.1 & 64.0 & 62.5 & 63.6 & 60.0 & 84.2 \\
\hline 2.5 to 3.5 & 23.1 & 17.4 & 30.8 & 12.0 & 37.0 & 28.0 & 20.8 & 27.3 & 30.0 & 5.3 \\
\hline 1 to 2 & 0.0 & 13.0 & 7.7 & 8.0 & 14.8 & 8.0 & 8.3 & 9.1 & 10.0 & 10.5 \\
\hline
\end{tabular}

\subsubsection{Age of the System vs. Infrastructure}

One possible explanation for the prevalence of water systems with higher scores is the age of the systems. The 17 systems built by PCV were relatively new as shown in Table 20. The average age of the system was only four years old, and there were already many problems observed with the infrastructure. This is a concern when the design life of a RWS is typically between 15-20 years. The 11 water systems rehabilitated or expanded by PCV were excluded from Table 20 because the age of each component of their system varied significantly, making it impractical to label them in one age group. 


\begin{tabular}{|l|c|c|}
\hline Community & $\begin{array}{c}\text { Age of the } \\
\text { System } \\
\text { (years) }\end{array}$ & $\begin{array}{c}\text { Infrastructure } \\
\text { Score }\end{array}$ \\
\hline Cerro Miguel & 8 & 1.3 \\
\hline El Zapote & 7 & 3.3 \\
\hline Ibiari-Gucamayoi & 7 & 3.4 \\
\hline Junquito & 4 & 4.6 \\
\hline La Pedagoza & 1 & 4.5 \\
\hline Monte Rico & 3 & 3.9 \\
\hline Nudobidy & 2 & 4.8 \\
\hline Oriente de Risco & 6 & 3.8 \\
\hline Playa Balsa & 4 & 4.5 \\
\hline Punta Valiente & 7 & 3.1 \\
\hline Quebrada Cacao & 2 & 4.0 \\
\hline Quebrada Mina & 1 & 4.5 \\
\hline Rio Bonito & 3 & 4.7 \\
\hline Rio Pavo & 1 & 5.0 \\
\hline Salto Dupi & 6 & 3.4 \\
\hline Tobobe & 4 & 3.4 \\
\hline Valle Risco - Bario & 2 & 4.3 \\
\hline Santos & $\mathbf{4}$ & $\mathbf{3 . 9}$ \\
\hline Average & & \\
\hline
\end{tabular}

Table 20. Age of water systems built by PCV and its corresponding infrastructure score.

In order to examine the relationship between the age of the system and the deterioration of infrastructure, a scatter plot with linear regression analysis was prepared (Figure 23). The age of the system was designated as independent variable (x-axis) and the score of infrastructure calculated previously was designated as dependent variable (y-axis).

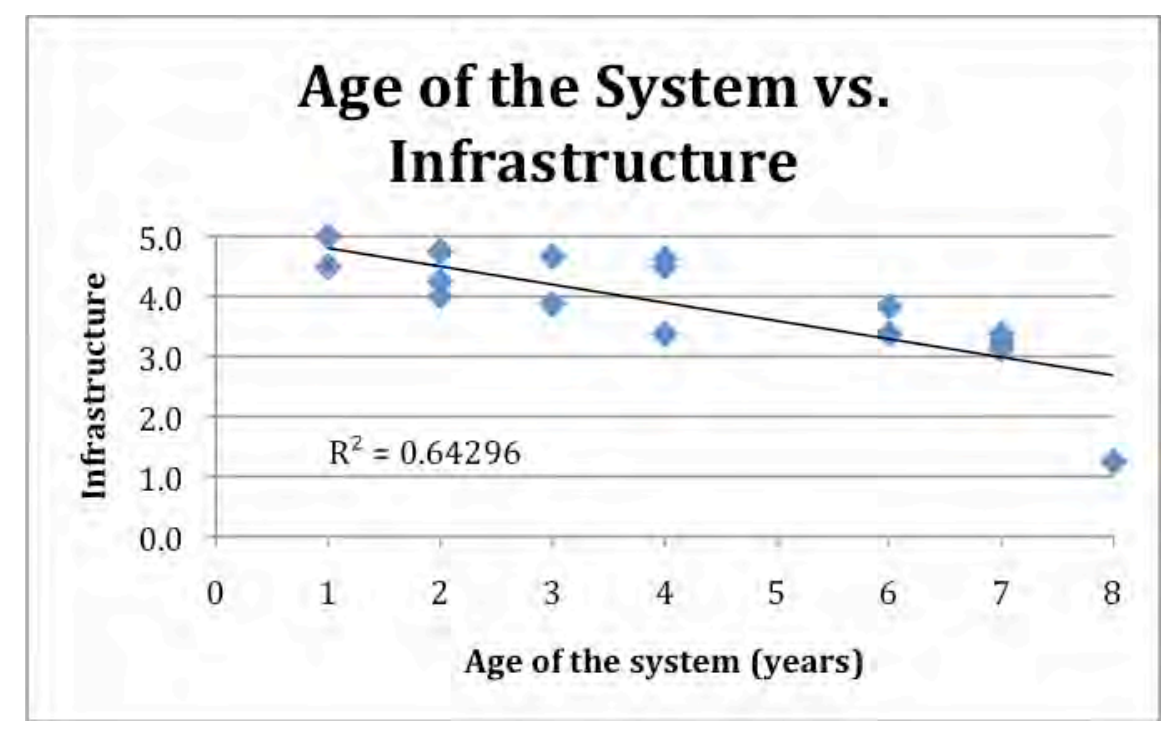

Figure 23. Age of the system (years) vs. infrastructure score. 
Figure 23 suggest that the age of the system is correlated with the deterioration of infrastructure for this sample. Additionally, as these systems approach closer to their design life, the rate of deterioration would increase as well. However, the scale of each water system, quality of construction and level of maintenance could also affect the deterioration of infrastructure.

\subsubsection{Major Rehabilitation and Expansion}

No matter how well the communities maintain their water systems, at some point, these water systems will require major rehabilitation or expansion work, or they will need to be replaced by a new system. The observations made in this study coincide with the World Bank's (2007) concern that the majority of rural communities are not able to generate sufficient income to make this type of major investment on their own. Most likely they will need an outside organization to subsidize the majority of the cost.

However, using outside funds to pay for the major follow-up work for water systems is not unprecedented. Even most towns and cities in the industrialized countries are not completely self-sufficient with their water systems. For example, in the United States, the local municipality collects the monthly water bill in order to cover the cost of daily operation and maintenance. In case the municipality needs a major rehabilitation work or replace an existing system, they typically would apply for the state or federal grant to cover the majority of the cost and they would hire an outside contractor to carry out the job. Perhaps it is not practical to expect low-income communities in the developing world to be responsible for all the major investments when even most towns and cities in the developed world still rely on outside assistance.

\subsection{Additional Observations}

During the post-project assessment of the 28 water systems, several recurring themes were observed. Although these factors were not included as one of the indicators established in the study methodology, the literature review revealed their relative importance to the sustainability of water systems.

\subsubsection{Inter-Institutional Coordination}

The lack of collaboration between national governments, donors and civil society is considered to be one of the main factors hindering effectiveness of development efforts (Kakande, 2004). 
Although these organizations supposedly have the same goal of serving the world's poor, there has been very little coordination of efforts, lack of transparency and a lot of mistrust. The difficulty of coordinating efforts between the Peace Corps EH sector and MINSA, which both have the same goal of providing improved water supply and sanitation, was also observed.

For example, the community of San Pedro in the Cocle province had been soliciting MINSA for many years to receive assistance with the extension of their water system to connect to another water source. Frustrated by the years of inaction, they solicited for a PCV and worked together to construct a spring box, install about one mile of 2 " tubes to connect to the existing system, and construct a 5,000-gallon storage tank. However, a year after the project was complete, MINSA came in and installed a 3" transmission line along the same path and constructed a 10,000-gallon storage tank right next to the tank built a year before, as seen in Figure 24 .

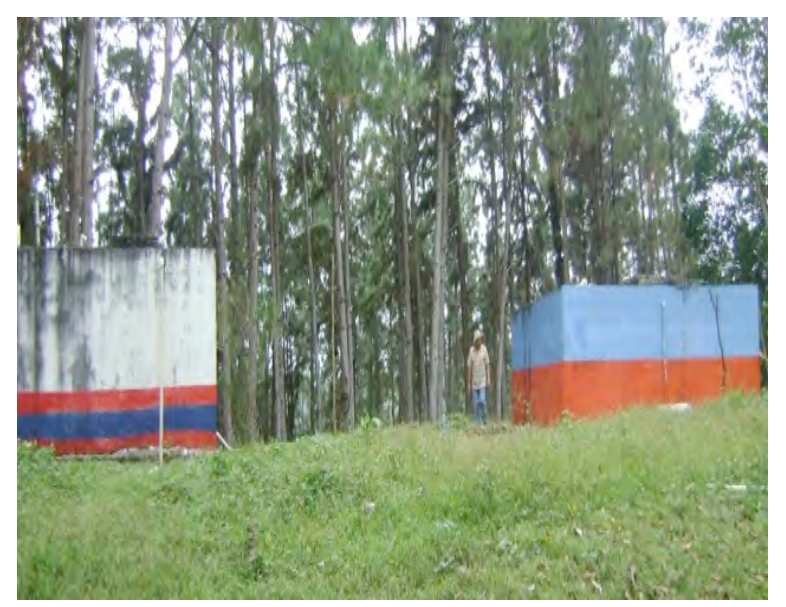

Figure 24. 5,000-gallon tank constructed by a PCV and 10,000-gallon tank constructed by MINSA a year later.

In the community of Nuevo Paraiso, Darien, a PCV and the local MINSA office supposedly made an agreement that the PCV would construct the spring box and storage tank, and MINSA would finance the cost of materials for the transmission line and distribution system. Four years after PCV left the community, the spring box and storage tank remained unused, while the community still suffered from the lack of reliable water service because MINSA had yet to complete its promise. MINSA finally approved the project in 2009, but they claimed that they would have to construct a new storage tank. Apparently, according to the MINSA procedure, they need to paint their logo on their infrastructure projects. This implies that for water systems, they are required to construct the storage tank themselves in order to have the eligibility to paint it with their logo. 


\subsubsection{Operator's Manual}

During the assessment, few communities possessed an operator's manual for basic maintenance and trouble-shooting. This was even more problematic for systems with complicated components such as pumps and volcanic sand filter with automatic backwash. The water committee members expressed a lack of knowledge regarding how to repair minor damages or who they could contact if these components ever break down. Both the EH sector and MINSA currently lack standardized operator's manual for RWS.

\subsubsection{Inequity}

Mukherjee and van Wijk (2003) identified that the economic, social and ethnic differences within each community cause inequity of access to water supply. They observed that poorest and most marginalized members of each community tend to receive the least benefit from the water systems. Although there are certainly economic and social disparities within most communities in rural Panama, this did not appear to be causing inequity of access to water supply for the communities visited. The inequity seemed to result from the differences in the geographical location of the houses, where houses located farther away from the source and on a higher elevation have more difficulty connecting to the system or suffer from more intermittent services. Additionally, since most communities do not punish users for not paying the monthly tariffs, even if certain household does not have the ability to pay, they would not lose their service. Unfortunately, assessing the relationships between gender and water supply was beyond the scope of this study.

\subsubsection{Incentive to Participate}

The lack of incentive to participate as a member of the water committee has been identified as one of the main factor affecting the sustainability of RWS (Lockwood, 2003). The following are some of the common complaints that the committee members shared during the assessment:

- "Nobody appreciates all the work I am putting in, but if there ever is a problem, they immediately blame me."

- "People believe that water committees are responsible for everything that happens with the water system. They don't understand that entire community is responsible for its well-being and we only act as managers."

- "If I tell people to pay their monthly tariffs or repair their leaky taps, and threaten to cut their water service if they don't comply, they criticize me for being too authoritative." 
Many water committee members are forced to bear the criticisms of their fellow community members, while dedicating their personal time without any economic rewards. The success of community management (CM) model promoted by so many outside organizations depends so much on the presence of strong leadership by individuals within each community willing to make personal sacrifices for the common good. Thus the CM model has the danger of perpetuating "the exploitation of the great by the small phenomenon, where those community members with less interest in the public good free-ride on the efforts and contribution made by those with greater interest in the public good" (Olson, 1973 quoted in Mansuri and Rao, 2003).

\subsubsection{Knowledge Transfer}

The lack of knowledge transfer was another common problem identified by Lockwood (2003). While speaking with the newly elected water committee members, many of them admitted that they have limited knowledge regarding the water system and its history. They complained that the previous committee did not leave them with any kind of documents or directions on how to carry out their responsibilities. This could be problematic even for the high performing water committees. If they ever leave the community, become discouraged with the work or get voted out of position, there is no mechanism to ensure that they would train the new water committee and hand over all the documents that they possess.

\subsection{Request for Follow-Up Support}

Although the assessment showed that higher scores were more prevalent, it does not preclude the need for additional support. Most communities, including the ones with higher scores, requested some kind of additional assistance from an outside organization. The following are possible types of follow-up support that communities may need for their water systems. The specific recommendations for each community can be found in Appendix F.

- Damage repairs for the spring boxes and storage tanks.

- Cost sharing or full financing for major repairs.

- Connection to an additional water source.

- Conflict management for watershed issues.

- Installment of pressure-regulators for houses or neighborhoods with excessive pressure.

- Installment of chlorinator and reliable supply of chlorine tablets.

- J AAR certification.

- Community motivation for better participation. 
- Water committee trainings that include the following themes (the water committee training seminars was not standardized until 2008):

oAccounting and Transparency.

oWatershed protection.

o Basic concepts of gravity-fed water systems.

oThermal forming to produce higher quality joints for damage repairs in the tubes. oLeadership.

\subsection{Conclusion}

Overall, the data collection method developed for this study proved to be effective in assessing general problems encountered by each community regarding their water systems. However, data for indicators such as willingness to pay, accounting/transparency and active water committee members were much more difficult to collect. There were also many situations where the scoring indicator was not relevant or applicable. That is why rather than mechanically giving scores to each community, the focal point of the assessment was to engage in a dialogue with different water committee members and users.

The assessment of 28 communities across the country revealed that the current state of physical infrastructure, as well as the financial, managerial and administrative capabilities of water committees varied depending on the community. While some communities are enjoying continued service and their water committee completing all of its responsibilities, others have seen their water systems fall apart and be abandoned.

Overall, the higher scores were much more prevalent than the lower scores. This could be because the average age of 17 water systems built by PCV was only four years old. However, high scores do not imply that water systems are sustainable. The scores only represent the current state of the infrastructure and water committee, and their performance will inevitably fluctuate over time.

Finally, most communities, including the ones with the highest scores, requested some kind of additional technical, financial or legal help. This conclusion concurs with the growing recognition in the rural water supply sector that communities should receive some kind of 
Post-Project Assessment and Follow-Up Support for Community Managed Rural Water Systems in Panama

continued external assistance to ensure that the benefits from the water systems are sustained beyond their design life. 


\section{Chapter 5 - Incorporating Institutional Support Mechanism into the Environmental Health Sector Policy}

The post-construction assessment of the 28 water systems revealed that communities do need continued external assistance to ensure the longevity of their water systems, which coincided with the most recent literature and research (Sara and Katz, 1997; Newman et al, 2002; Lockwood, 2002, 2003, 2004; IRC, 2003; Annis, 2006; Schweitzer, 2009). A new paradigm is forming in the rural water supply and sanitation sector, based on the recommendation that efforts at participatory development should continue beyond the implementation phase. That is why the Peace Corps Environmental Health sector should incorporate the institutional support mechanism (ISM) into its sector policy, enabling them to systematically provide follow-up support to the communities where volunteers have worked in the past.

Although community members can, and should, assume the majority of responsibility to maintain their water systems, in most cases they will need some kind of external assistance. The ISM refers to the capacity of an organization to provide long-term support to rural communities without undermining the responsibilities of community management or creating long-term dependency (Lockwood 2002). Thus, the challenge is to determine the scope and frequency of external assistances that would vary significantly depending on the internal and external factors of each community.

\subsection{Rural Water Information System}

In order to assist the $\mathrm{EH}$ sector in determining the scope and frequency of continued assistance, an inventory of the 28 past EH water project has been created based on this study. This database is similar to the rural water information system (SIAR) utilized in the Technician in Operation and Management (TOM) program in Honduras (Trevett, 2001). This database consists of the following information for each community: Location (corregimiento, district and province), history of the system, current state of the system based on the assessment, recommendation, and community contact information. The database should be updated for all outside interventions carried out in these communities. 


\subsection{Circuit Rider}

The circuit rider or mobile technician concept used in the TOM program could also be adapted for the $\mathrm{EH}$ sector. The $\mathrm{EH}$ program director is already thinking about assigning experienced volunteers to serve as a full time circuit rider that would travel to the communities in need and provide additional assistance. The inventory created for this study would serve as a guideline to identify the communities and the type of assistance they would need.

If the EH sector does decide to assign full time circuit riders, the following points should be considered while designing and establishing the procedures and roles of circuit riders:

- Collecting tariffs as an incentive to receive additional help: Lockwood (2003) identified that tariff collection to cover recurrent cost and the presence of some sort of long-term external support are the two most prominent factors in ensuring sustainability of water systems. One way to ensure that both conditions are met is by making it a requirement that in order to receive additional help, the communities must share their ledger, balance sheet and receipts with the circuit rider and prove that users are paying for their services. Hence, by explaining to the community that the extent of additional help they would receive depends on their willingness to pay and money management, they would have an additional incentive to improve their financial performances.

- Involve community members in the monitoring and evaluation process through visual aid: Each intervention should start with community members evaluating themselves and their water systems. The benchmark scoring systems established for this research would serve as a tool to help them indentify their current situation and visualize what an ideal situation would look like. However, the abstract nature of descriptive categories might be confusing for many community members. That is why there should be a visual representation of each score description to allow even people with limited education levels to participate in the investigation.

- Standardize the financial assistance: One of the most difficult issues regarding follow-up support is dividing up the financial burdens. For example, if the community identified repairing damages as a top priority, who will pay for the materials? Should the community still provide $25 \%$ of the project cost or should they provide everything? What 
if the problems resulted from poor construction of spring boxes or storage tanks? Should the community still bear the whole cost? During the assessment, some communities were willing to pay for half of the materials for rehabilitation, while others wanted the Peace Corps to finance all the materials cost. The financial issue is always one of the most sensitive subjects in community development projects, and if this is dealt with poorly, the continued assistance will most likely perpetuate paternalism and outside dependency.

- Flexible budgeting: The circuit riders should have flexible budgeting for their operations. If they do decide to provide financial assistance to some communities, they should not have to go through the entire standard PC application process to secure funding for each community. The focus should be on how to spend the money well rather how to get the money and spend it all within a certain timeframe.

- Involve the rest of the community in training: The current model for the PC water committee training seminar only provides training to members of the water committee. However, studies have indicated that RWS were more sustainable and had a greater health impact when the whole community was involved in the training process (Newman et al., 2002). Possible topics for the community-wide training program could include the importance of tariff payment, how to repair leaky taps and pipes, hygiene and household treatment, reinforcement of J AAR rules, etc.

- Operator's Manual: The EH sector currently does not have a standardized operator's manual. If the EH or MINSA ever develops an operator's manual, multiple community members should receive this document. There have many cases where the member with all the information lost them or left the community. This operator's manual should also include a copy of the JAAR regulations.

- Assist in the conflict management: Conflicts regarding water resources are inevitable in most cases. Although PCVs are often not in the position to become directly involved with the internal or external conflicts that communities face, there are ways to indirectly assist them. For example, if there is an issue with the watershed rights, the PCV could act as a liaison with the local MINSA or environmental authority (ANAM) offices that have the legal authority to become a mediator in such situation. If a 
community member is questioning the authority of the water committees, then referring to the JAAR regulation would help to resolve doubts or conflicts.

- Provide assistance to new volunteers or other volunteers in need: The circuit rider could also travel to the communities where volunteers currently live to provide additional help and give them a live example of how to facilitate a participatory decisionmaking process. More experienced development practitioners and water technicians serving as mentors to the less experienced staff proved to be successful in other organizations (Sara and Katz 1997; Parfitt, 2004).

- Reward high performing water committees: High performing water committees often do not get the recognition they deserve for their hard work and personal sacrifices. Similar to the TOM program in Honduras, the water committees with good track records should be presented wit certifications in front of the entire community and be encouraged to keep up with the good work. Involving MINSA technicians in this process would also be beneficial in order to designate the committees as official J AAR members.

\subsection{Organizational Learning}

The author hopes to contribute to the organizational learning of the Environmental Health sector and Peace Corps Panama as a whole. One of the key aspects of the organizational learning is to take "time to reflect upon action and experience in order to reframe the problem or issue and gain relevant insights, leading to improved future actions and performance" (Pasteur and Scott-Villiers, 2004). Accordingly, this research aims to provide critical reflection of the past water projects, which will hopefully lead to new actions by incorporating ISM into the sector policy. However, even if the circuit riders are able to provide additional assistance to these rural communities, this will inevitably lead to new problems and challenges. Once again, this will require the organization as a whole to critically reflect and question the current strategy and procedure. Such continuous cycle of action and reflection is the only way to solve complex and dynamic problems posed by community based participatory development. 


\section{Reference}

Annis, J. E. (2006). Assessing progress of community managed gravity flow water supply system using rapid rural appraisal in the Ikongo District in Madgascar. (Master's report, Michigan Technological University). Available at www.cee.usf.edu/peacecorps

Bank-Netherlands Water Partnership (BNWP). (2009). Project No. 007: Follow-Up Support to Communities after Construction of Rural Water Supply and Sanitation Facilities; three country case study: Peru, Ghana and Bolivia. Netherlands: BNWP.

Brikke, F. (2000). Operation and maintenance of rural water supply and sanitation: A training packet for operators and managers. WHO and IRC.

Braithwaite, B. M. (2009). Training water committees in Bocas del Toro, Panama: A case study of Peace Corps Volunteers' initiative to improve rural water system management. (Master's report, Michigan Technological University).

Easterly, W. (2006). The white man's burden: How the west's effort to aid the rest have done so much ill and so little good. New York: Penguin.

Feachem, R. (1980). Community Participation in Appropriate Rural Water Supply and Sanitation Technology: The mythology of decade. Proc. R. Soc. Lond. B209 pp15-29

Freire, P. (1970). Pedagogy of the oppressed. Spain: Siglos XXI Editores.

Gross, B., van Wijk, C., and Mukherjee, N. (2002). Linking sustainability with demand, gender and poverty: A study in community-managed water supply projects in 15 countries. WSP and IRC.

Google. (2010). Google Earth. Map created using GPS points collected by author and reprinted here in accordance with Term of Use. Retrieved on March 20, 2010. http:// www.google.com/ permissions/geoguidelines.html 
Hayward, C., Simpson, L., and Wood, L. (2004). Still left out in the cold: Problematising participatory research and development. Sociologia Ruralis. 44, (1), pp95-108.

International Water and Sanitaiton Centre (IRC). (2003). About community management. Retrieved May 14, 2010 from IRC website, http:// www2.irc.nl/ manage/ index.html

Kakande, M. (2004). The donor-government-citizen frame as seen by a government participant. In Groves, L. et al. (Edit) Inclusive aid: Changing power and relationships in international development (Pp87-96). London: Earthscan.

Karp, A., Meza, L. C., and de Leon, S. C. (1999). Water as the source of community empowerment: Part 1. Waterlines. 17, (3), pp19-21

Lockwood, H. (2002). Institutional Support Mechanisms for Community-managed Rural Water Supply \& Sanitation Systems in Latin America. Arlington, VA: USAID Environmental Health Project.

Lockwood, H. (2003). Post-project sustainability: Follow-up support to communities literature review and desktop study of RWSS Project Documents. Washington DC: World Bank.

Lockwood, H. (2004). Scaling up of community management of rural water supply. A thematic overview paper. Netherlands: IRC.

Mansuri, G. and Rao, V. (2003). Evaluating Community-Based and Community-Driven Development: A Critical Review of Evidence. Washington, DC: The Development Research Group, The World Bank.

Ministry of Health (MINSA). (1994). Decretivo Ejecutivo No. 40. Republic of Panama: MINSA

Mukherji N. and van Wijk C. (2003). Sustainability Planning and Monitoring in Community Water Supply and Sanitation. WSP and IRC. 
Narayan, Deepa. (1993). Participatory Evaluation: Tools for Managing Change in Water and Sanitation. Washington DC: The World Bank.

Newman, J., Pradham, M., Rawlings, L. B., Ridder, G., Coa, R., and Evia, J. L. (2002). An impact evaluation of education, health, and water supply investments by the Bolivian Social Investment Fund. The World Bank Economic Review. 16, (2), pp241-274

Nkongo, D. (2009). Management and Regulation for Sustainable Water Supply Schemes in Rural Communities. Dar es Salaam, Tanzania: WaterAid Tanzania.

Orr, B., and Anis, J. (2009). Participatory approaches and community management in engineering projects. In J . R. Mihelcic, et al. Field guide to environmental engineering for development workers (pp. 31-56). Virginia: ASCE.

Pasteur, K., and Scott-Villiers, P. (2004). Minding the gap through organizational learning. In Groves, L. et al. (Edit) Inclusive aid: Changing power and relationships in international development (Pp87-96). London: Earthscan.

Parfitt, T. (2004). The ambiguity of participation: A qualified defense of participatory development. Third World Quarterly. 25, (3), pp537-556

Programa Nacional de Agua y Saneamiento Rural (PRONSAR). (2003). Estudios de base para implementación de proyectos de agua y saneamiento en las áreas rurales. Lima, Peru: Unidad de Gestión del Proyecto Programa Nacional de Agua y Saneamiento Rural

Sara, J ., and Katz, T. (1997). Making rural water supply sustainable: Report on the impact of project rules. Washington DC: WSP.

Schweitzer, R. (2009). Assessment of sustainability of systems built by National Institute of Potable Water and Peace Corps, Dominican Republic. (Master's thesis, Michigan Technological University). Available at www.cee.usf.edu/ peacecorps

Sugden, S. (2003). Indicators for the water sector: examples from Malawi. United Kingdom: WaterAid 
Trevett, A. (2001). The SANNA Technician in Operation and Maintenance Program in Honduras. In F. Rosensweig (Ed.), Strategic Paper No 1: Case Study on Decentralization of Water and Sanitation Services in Latin America. Washington DC: USAID Environmental Health Project.

UN Human Development Report. (2009). Retrieved May 17, 2010 from United Nations Development Programme website, http:// hdrstats.undp.org/ en/ indicators/ 104.html

van Wijk, C. and Postma, L. (2003). MPA: a new methodology for participatory monitoring. Waterlines. 22, (1), pp6-7

Peace Corps Panama. (2010). Cuerpo de Paz: Programa de Salud Ambiental, hoja de datos 2010. Republic of Panama: Peace Corps Panama.

White, A. (1981). Community participation in water and sanitation: Concepts, strategies, and methods. Netherlands: IRC

WHO/UNICEF. (2010). Progress on sanitation and drinking-water: 2010 Update. WHO/ UNICEF J oint Monitoring Programme For Water Supply and Sanitation.

Water and Sanitation Program (WSP) - South Asia. (1998). Sustainability monitoring: The VIP way. WSP.

World Bank. (2007). Project appraisal document on a proposed loan of US\$32 Million to Republic of Panama for a water supply and sanitation in low-income communities. World Bank - Sustainable Development Department, Latin America and Caribbean Region. 


\section{Appendix}

\section{Appendix A. Scoring Scale for the Ten Indicators}

\begin{tabular}{|c|c|c|c|c|c|c|}
\hline Outcome Indicators & 1 & 2 & 3 & 4 & 5 & Notes \\
\hline Watershed & $\begin{array}{c}\text { No tree coverage, } \\
\text { presence of } \\
\text { contaminants nearby } \\
\text { (open defecation or } \\
\text { latrines, animals, } \\
\text { agrochemicals), no } \\
\text { formal agreement with } \\
\text { the owner }\end{array}$ & $\begin{array}{c}\text { No tree coverage, no } \\
\text { contaminants, no } \\
\text { formal agreement with } \\
\text { the owner }\end{array}$ & $\begin{array}{c}\text { Some tree coverage, } \\
\text { no contaminants, } \\
\text { verbal agreement with } \\
\text { the owner }\end{array}$ & $\begin{array}{l}\text { Area is covered with } \\
\text { lush forest or being } \\
\text { reforested, no } \\
\text { contaminants, verbal } \\
\text { agreement with the } \\
\text { owner }\end{array}$ & $\begin{array}{l}\text { Area is covered with } \\
\text { lush forest or being } \\
\text { reforested, no } \\
\text { contaminants, formal } \\
\text { written agreement with } \\
\text { the land owner to } \\
\text { keep the area } \\
\text { protected }\end{array}$ & \\
\hline Source Capture & $\begin{array}{l}\text { Not protected from } \\
\text { runoff, majority of } \\
\text { water not captured }\end{array}$ & $\begin{array}{c}\text { Runoff could enter the } \\
\text { source, majority of } \\
\text { water not captured }\end{array}$ & $\begin{array}{l}\text { No runoff entering the } \\
\text { source, some water } \\
\text { not being captured }\end{array}$ & $\begin{array}{c}\text { No runoff entering the } \\
\text { source, majority of } \\
\text { water captured, some } \\
\text { leaks }\end{array}$ & $\begin{array}{c}\text { No runoff entering the } \\
\text { source, all the water } \\
\text { captured, no leaks }\end{array}$ & \\
\hline Transmission Line & $\begin{array}{c}\text { Majority of tubes are } \\
\text { exposed, significant } \\
\text { amount of water being } \\
\text { lost from damages or } \\
\text { poorly made joints, } \\
\text { uncovered hole for air } \\
\text { blockage }\end{array}$ & $\begin{array}{l}\text { Majority of tubes are } \\
\text { exposed, some water } \\
\text { being lost from } \\
\text { damages or poorly } \\
\text { made joints, } \\
\text { uncovered hole for air } \\
\text { blockage }\end{array}$ & $\begin{array}{l}\text { Some exposed tubes, } \\
\text { some water being lost } \\
\text { from damages or } \\
\text { poorly made joints, } \\
\text { hole for air release } \\
\text { covered with a piece } \\
\text { of stick or other } \\
\text { smaller material }\end{array}$ & $\begin{array}{c}\text { Majority of tubes } \\
\text { buried, little water } \\
\text { being lost from } \\
\text { damages, joints well } \\
\text { made, air release hole } \\
\text { covered with a piece } \\
\text { of stick or other } \\
\text { smaller material }\end{array}$ & $\begin{array}{l}\text { All tubes buried, no } \\
\text { leaks, joints well made } \\
\text { air release valves } \\
\text { installed in proper } \\
\text { place }\end{array}$ & \\
\hline Storage Tank & $\begin{array}{c}\text { Tank size is too small, } \\
\text { major leakage } \\
\text { observed, never have } \\
\text { been cleaned }\end{array}$ & $\begin{array}{c}\text { Tank size too small, } \\
\text { some leakage } \\
\text { observed, cleaned } \\
\text { less than once a year }\end{array}$ & $\begin{array}{c}\text { Sufficient tank size, } \\
\text { very little leakage } \\
\text { observed, cleaned } \\
\text { less than once a year }\end{array}$ & $\begin{array}{c}\text { Sufficient tank size, no } \\
\text { leakage observed, } \\
\text { cleaned at least once } \\
\text { year }\end{array}$ & $\begin{array}{l}\text { Sufficient tank size, no } \\
\text { leakage observed, } \\
\text { cleaned periodically }\end{array}$ & \\
\hline Distribution System & $\begin{array}{l}\text { Leaky or broken taps, } \\
\text { no valves, major } \\
\text { inequity of water } \\
\text { pressure and flow, } \\
\text { exposed and leaky } \\
\text { tubes }\end{array}$ & $\begin{array}{l}\text { Leaky or broken taps, } \\
\text { no valves, some } \\
\text { inequity of water } \\
\text { pressure and flow, } \\
\text { exposed and leaky } \\
\text { tubes }\end{array}$ & $\begin{array}{l}\text { Some leaky or broken } \\
\text { taps, control valves, } \\
\text { some inequity of water } \\
\text { pressure and flow, } \\
\text { exposed tubes, } \\
\text { minimum leaks }\end{array}$ & $\begin{array}{c}\text { Adequate pressure } \\
\text { and flow at all houses, } \\
\text { control valves, very } \\
\text { little leaky or broken } \\
\text { taps, tubes buried, } \\
\text { minimum leaks }\end{array}$ & $\begin{array}{l}\text { Adequate pressure } \\
\text { and flow at all houses. } \\
\text { Physical infrastructure } \\
\text { is intact including tap } \\
\text { stands, service line } \\
\text { control valve, main } \\
\text { line control valves, } \\
\text { tubes are buried. }\end{array}$ & \\
\hline System Reliability & $\begin{array}{c}\text { Majority of users do } \\
\text { not have enough } \\
\text { water all year around }\end{array}$ & $\begin{array}{c}\text { Majority of users do } \\
\text { not have enough } \\
\text { water during the dry } \\
\text { season, some users } \\
\text { have enough water } \\
\text { during the rainy } \\
\text { season } \\
\end{array}$ & $\begin{array}{c}\text { Some users have } \\
\text { sufficient water during } \\
\text { the dry season, } \\
\text { majority of users have } \\
\text { enough water during } \\
\text { the rainy season }\end{array}$ & $\begin{array}{c}\text { Majority of users have } \\
\text { sufficient water even } \\
\text { during the dry season, } \\
\text { everybody has } \\
\text { enough water during } \\
\text { the rainy season }\end{array}$ & $\begin{array}{c}\text { All users have } \\
\text { sufficient water even } \\
\text { during the dry season }\end{array}$ & \\
\hline Willingness to Pay & $x<20 \%$ & $20 \%<X<50 \%$ & $50 \%<X<70 \%$ & $70 \%<X<90 \%$ & $X>90 \%$ & $\begin{array}{c}\% \text { of people } \\
\text { who have paid } \\
\text { by the end of } \\
\text { the year }\end{array}$ \\
\hline Accounting/Transparency & $\begin{array}{c}\text { No ledger, no receipts, } \\
\text { never reports to } \\
\text { community }\end{array}$ & $\begin{array}{c}\text { Ledger, no receipts } \\
\text { kept, never reports to } \\
\text { community }\end{array}$ & $\begin{array}{c}\text { Ledger, some receipts } \\
\text { are kept but } \\
\text { disorganized, reports } \\
\text { to community once a } \\
\text { year }\end{array}$ & $\begin{array}{c}\text { Ledger, some receipts } \\
\text { are kept and well } \\
\text { organized, and report } \\
\text { to community once a } \\
\text { year }\end{array}$ & $\begin{array}{l}\text { Ledger, all receipts } \\
\text { kept and well } \\
\text { organized, reports to } \\
\text { community } \\
\text { periodically }\end{array}$ & \\
\hline Maintenance & $\begin{array}{l}\text { Damages are never } \\
\text { repaired }\end{array}$ & $\begin{array}{c}\text { Damages are only } \\
\text { repaired when there is } \\
\text { a major water } \\
\text { shortages }\end{array}$ & $\begin{array}{l}\text { Damages are repaired } \\
\text { less than once a year }\end{array}$ & $\begin{array}{c}\text { Damages are repaired } \\
\text { periodically, multiple } \\
\text { times a year }\end{array}$ & $\begin{array}{c}\text { Damages are repaired } \\
\text { immediately }\end{array}$ & \\
\hline $\begin{array}{c}\text { Active water committee } \\
\text { member }\end{array}$ & 1 member & 2 members & 3 members & 4 members & 5 or more members & \\
\hline
\end{tabular}




\section{Appendix B. Scoring Scale for the Ten Indicators in Spanish}

\begin{tabular}{|c|c|c|c|c|c|c|}
\hline Indicador de resultados & 1 & 2 & 3 & 4 & 5 & Notas \\
\hline Cuenca & $\begin{array}{l}\text { No árboles, presencia } \\
\text { de contaminantes } \\
\text { (letrinas, animales, } \\
\text { agroquímicos), sin } \\
\text { acuerdo con el dueño } \\
\text { de la tierra }\end{array}$ & $\begin{array}{c}\text { No cobertura de } \\
\text { árboles, no } \\
\text { contaminantes, sin } \\
\text { acuerdo con el dueño } \\
\text { de la tierra }\end{array}$ & $\begin{array}{l}\text { Poca cobertura de } \\
\text { árboles, no } \\
\text { contaminantes, } \\
\text { acuerdo verbal con el } \\
\text { dueño de la tierra }\end{array}$ & $\begin{array}{c}\text { Mucha cubertura de } \\
\text { árboles o } \\
\text { reforestación de la } \\
\text { zona, no } \\
\text { contaminantes, } \\
\text { acuerdo verbal con el } \\
\text { dueño de la tierra }\end{array}$ & $\begin{array}{l}\text { Mucha cubertura de } \\
\text { árboles o } \\
\text { reforestación de la } \\
\text { zona, no } \\
\text { contaminantes, } \\
\text { acuerdo formal y } \\
\text { escrito con el dueño } \\
\text { de la tierra }\end{array}$ & \\
\hline Captación de la Fuente & $\begin{array}{c}\text { No están protegida del } \\
\text { agua superficial, } \\
\text { mayor parte del agua } \\
\text { no se captura }\end{array}$ & $\begin{array}{c}\text { Agua superficial } \\
\text { puede entrar la fuente, } \\
\text { mayor parte del agua } \\
\text { no se captura }\end{array}$ & $\begin{array}{c}\text { Agua superficial no } \\
\text { puede entrar la fuente, } \\
\text { poco agua no se } \\
\text { captura, poco agua se } \\
\text { escapa }\end{array}$ & $\begin{array}{c}\text { Agua superficial no } \\
\text { entra la fuente, } \\
\text { mayoría del agua se } \\
\text { captura, poco agua se } \\
\text { escapa }\end{array}$ & $\begin{array}{l}\text { Agua superficial no } \\
\text { entra la fuente, toda } \\
\text { agua se captura, no } \\
\text { escapa de agua }\end{array}$ & \\
\hline Línea de transmisión & $\begin{array}{c}\text { Mayoría de los tubos } \\
\text { expuestos, mucha } \\
\text { perdida del agua por } \\
\text { los daños o empate } \\
\text { mal hecho, agujeros } \\
\text { por choque del aire no } \\
\text { cubiertos }\end{array}$ & $\begin{array}{c}\text { Mayoria de los tubos } \\
\text { expuestos, poca } \\
\text { perdida del agua por } \\
\text { los daños o empate } \\
\text { mal hecho, agujeros } \\
\text { por choque del aire no } \\
\text { cubiertos }\end{array}$ & \begin{tabular}{|c|} 
Pocos tubos \\
expuestos, poca \\
perdida del agua por \\
los daños o empate \\
mal hecho, agujeros \\
por choque de aire \\
cubiertos con pedazo \\
de palito o otros \\
materiales pequeños \\
\end{tabular} & $\begin{array}{l}\text { Mayoría de los tubos } \\
\text { enterrados, poca } \\
\text { perdida del agua por } \\
\text { los daños o empate } \\
\text { mal hecho, agujero } \\
\text { por choque del aire } \\
\text { cubiertos con pedazo } \\
\text { de palito o otros } \\
\text { materiales pequeños }\end{array}$ & $\begin{array}{c}\text { Todos tubos } \\
\text { enterrados, no perdida } \\
\text { de agua, empate bien } \\
\text { hecho, válvulas de } \\
\text { respirador instaladas }\end{array}$ & \\
\hline Tanque de almacenamiento & $\begin{array}{c}\text { Tamaño del tanque } \\
\text { muy pequeño, mucha } \\
\text { escape del agua, } \\
\text { nunca se limpia }\end{array}$ & $\begin{array}{c}\text { Tamaño del tanque } \\
\text { muy pequeño, poco } \\
\text { escape del agua, se } \\
\text { limpia menos de una } \\
\text { vez al año }\end{array}$ & $\begin{array}{c}\text { Tamaño del tanque } \\
\text { suficiente, muy poco } \\
\text { escape del agua, se } \\
\text { limpia menos de una } \\
\text { vez al año }\end{array}$ & $\begin{array}{c}\text { Tamaño del tanque } \\
\text { suficiente, no escape } \\
\text { del agua, se limpia por } \\
\text { lo menos una vez al } \\
\text { año }\end{array}$ & $\begin{array}{c}\text { Tamaño del tanque } \\
\text { suficiente, no escape } \\
\text { del agua, se limpia } \\
\text { cada rato }\end{array}$ & \\
\hline Sistema de distribución & $\begin{array}{c}\text { Mayoría de las plumas } \\
\text { dañadas, mayoría de } \\
\text { los tubos expuestos, } \\
\text { mucha perdida del } \\
\text { agua, no llaves, } \\
\text { mucha desigualdad de } \\
\text { la presión y el caudal } \\
\text { de agua entre las } \\
\text { casas }\end{array}$ & $\begin{array}{c}\text { Mayoría de las plumas } \\
\text { dañadas, mayoría de } \\
\text { los tubos expuestos, } \\
\text { mucha perdida del } \\
\text { agua, no llaves, poca } \\
\text { desigualdad de la } \\
\text { presión y el caudal de } \\
\text { agua entre las casas }\end{array}$ & $\begin{array}{c}\text { Poca pluma dañada, } \\
\text { pocos tubos } \\
\text { expuestos, poca } \\
\text { perdida del agua, } \\
\text { Ilaves instalados, poca } \\
\text { desigualdad de la } \\
\text { presión y el caudal de } \\
\text { agua entre las casas }\end{array}$ & \begin{tabular}{|c|} 
Muy poca pluma \\
dañada, muy pocos \\
tubos expuestos, muy \\
poca perdida del \\
agua, llaves \\
instalados, todas \\
casas tienen \\
suficiente presión y \\
caudal de agua \\
\end{tabular} & $\begin{array}{c}\text { No pluma dañada, } \\
\text { todos tubos } \\
\text { enterrados, no perdida } \\
\text { del agua, llaves } \\
\text { instalados, todas } \\
\text { casas tienen } \\
\text { suficiente presión y } \\
\text { caudal de agua }\end{array}$ & \\
\hline Confiabilidad del sistema & $\begin{array}{c}\text { Mayoría de los } \\
\text { usuarios no tienen } \\
\text { suficiente agua todo el } \\
\text { año }\end{array}$ & $\begin{array}{c}\text { Mayoria de los } \\
\text { usuarios no tienen } \\
\text { suficiente agua } \\
\text { durante la época de } \\
\text { sequía, pocos } \\
\text { usuarios tienen } \\
\text { suficiente agua } \\
\text { durante la época } \\
\text { Iluviosa } \\
\end{array}$ & \begin{tabular}{|} 
Pocos usuarios tienen \\
suficiente agua \\
durante la época de \\
sequia, mayoría de \\
los usuarios tienen \\
suficiente agua \\
durante la época \\
lluviosa
\end{tabular} & $\begin{array}{c}\text { Mayoría de los } \\
\text { usuarios tienen } \\
\text { suficiente agua } \\
\text { durante la epoca de } \\
\text { sequía, todos tienen } \\
\text { suficiente agua } \\
\text { durante la epoca } \\
\text { lluviosa }\end{array}$ & $\begin{array}{c}\text { Todos usuarios tienen } \\
\text { suficiente agua todo el } \\
\text { año }\end{array}$ & \\
\hline Disposición a pagar & $x<20 \%$ & $20 \%<X<50 \%$ & $50 \%<X<70 \%$ & $70 \%<x<90 \%$ & $x>90 \%$ & $\begin{array}{l}\text { Porcentaje de } \\
\text { tarifas } \\
\text { mensuales } \\
\text { recolectadas } \\
\text { cada año }\end{array}$ \\
\hline Contabilidad y Transparencia & $\begin{array}{c}\text { No registro de pago, } \\
\text { no libro de } \\
\text { contabilidad, no } \\
\text { facturas, nunca } \\
\text { entrega un informe de } \\
\text { gastos a la comunidad }\end{array}$ & $\begin{array}{l}\text { Registro de pago pero } \\
\text { desorganizadas, no } \\
\text { libro de contabilidad, } \\
\text { no facturas, nunca } \\
\text { entrega un informe a } \\
\text { la comunidad }\end{array}$ & $\begin{array}{c}\text { Registro de pago bien } \\
\text { organizado, libro de } \\
\text { contabilidad pero } \\
\text { desorganizada, pocas } \\
\text { facturas guardadas } \\
\text { pero desorganizadas, } \\
\text { entrega un informe a } \\
\text { la comunidad una vez } \\
\text { al año } \\
\end{array}$ & \begin{tabular}{|c|} 
Registro de pago bien \\
organizado, libro de \\
contabilidad bien \\
organizado, pocas \\
facturas guardadas \\
pero organizadas, \\
entrega un informe a \\
la comunidad una vez \\
al año \\
\end{tabular} & $\begin{array}{c}\text { Registro de pago, libro } \\
\text { de contabilidad, y } \\
\text { todas facturas están } \\
\text { bien organizados, } \\
\text { entrega un informe a } \\
\text { la comunidad } \\
\text { periódicamente }\end{array}$ & \\
\hline Mantenimiento & $\begin{array}{c}\text { Nunca arregla los } \\
\text { daños }\end{array}$ & \begin{tabular}{|c|} 
Arregla los daños \\
solamente cuando hay \\
escasez de agua muy \\
grave
\end{tabular} & $\begin{array}{c}\text { Arregla los daños } \\
\text { menos de una vez al } \\
\text { año }\end{array}$ & $\begin{array}{c}\text { Arregla los daños } \\
\text { cada rato, varias } \\
\text { veces al año }\end{array}$ & $\begin{array}{l}\text { Arregla los daños } \\
\text { inmediatamente }\end{array}$ & \\
\hline Miembros activos de la directa & 1 miembros & 2 miembros & 3 miembros & 4 miembros & más de 5 miembros & $\begin{array}{l}\text { Miembro activo } \\
\text { significa una } \\
\text { persona que } \\
\text { cumple todos los } \\
\text { deberes de su } \\
\text { cargo }\end{array}$ \\
\hline
\end{tabular}




\section{Appendix C. Scores Given to Each Community}

\begin{tabular}{|c|c|c|c|c|c|c|c|c|c|c|}
\hline & 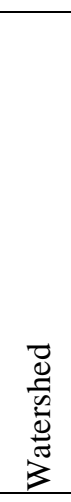 & 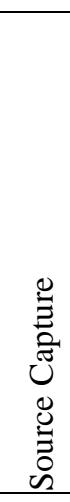 & 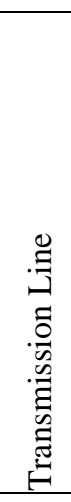 & 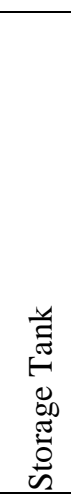 & 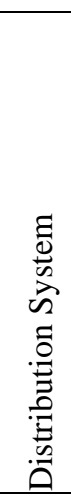 & 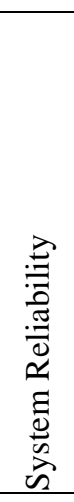 & $\begin{array}{l}\vec{\Xi} \\
0 \\
0 \\
0 \\
0 \\
0 \\
0 \\
\Xi \\
\equiv \\
0\end{array}$ & 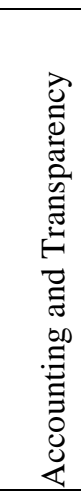 & 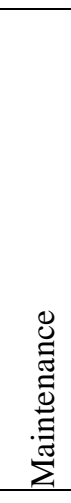 & 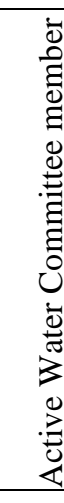 \\
\hline Bahia Azul & 4.0 & 3.0 & 3.5 & 3.0 & 2.0 & 3.0 & 4.0 & 2.0 & 2.0 & 5.0 \\
\hline Cayo Paloma & 5.0 & 4.5 & 4.0 & 2.0 & 3.5 & 5.0 & 4.0 & 4.0 & 3.0 & $\mathrm{X}$ \\
\hline Cerro Iglesia & 3.0 & 4.5 & 3.0 & 5.0 & 2.0 & 3.0 & 3.0 & 3.0 & 3.0 & 5.0 \\
\hline Cerro Miguel & $\mathrm{X}$ & 2.0 & 2.0 & NA & 1.0 & 1.0 & 1.0 & $\mathrm{X}$ & 1.0 & $\mathrm{X}$ \\
\hline Cerro Puerco & 3.0 & 5.0 & 4.0 & 4.0 & 2.5 & 3.0 & 2.0 & 4.0 & 3.0 & 5.0 \\
\hline Cerro Venado* & 4.0 & 5.0 & NA & 5.0 & 3.0 & 1.0 & $\mathrm{X}$ & $\mathrm{X}$ & $X$ & 2.0 \\
\hline $\begin{array}{l}\text { Corazón de Jesus } \\
\text { (Akunasadup) }\end{array}$ & 5.0 & NA & 2.5 & 5.0 & 5.0 & 4.0 & 5.0 & 5.0 & 4.0 & 5.0 \\
\hline El Zapote & 4.0 & 4.0 & 3.5 & 4.0 & 1.5 & 2.5 & $X$ & $X$ & 1.5 & $X$ \\
\hline Ibiari-Gucamayoi & 4.0 & 2.0 & 4.0 & 4.0 & 3.5 & 4.5 & 3.0 & 2.5 & 4.0 & 5.0 \\
\hline Junquito & 3.5 & 4.5 & 5.0 & 5.0 & 4.0 & 4.0 & 3.0 & 3.0 & 4.0 & $\mathrm{X}$ \\
\hline La Gloria & 3.5 & 5.0 & 4.0 & 3.0 & 4.0 & 4.0 & $\mathrm{X}$ & $\mathrm{X}$ & $\mathrm{X}$ & 1.0 \\
\hline La Pedagoza & 5.0 & 5.0 & 4.5 & NA & 4.0 & $\mathrm{X}$ & 4.0 & 4.0 & 5.0 & 5.0 \\
\hline Monte Rico & 4.0 & 3.0 & 4.0 & 4.0 & 4.5 & 5.0 & 4.0 & 3.0 & $\mathrm{X}$ & $\mathrm{X}$ \\
\hline Nudobidy & 5.0 & 5.0 & 4.0 & 5.0 & 5.0 & 5.0 & 5.0 & 5.0 & 5.0 & 5.0 \\
\hline Nuevo Paraiso & 3.0 & 3.0 & NA & NA & NA & NA & NA & NA & $\mathrm{NA}$ & $\mathrm{X}$ \\
\hline Oriente de Risco & 4.0 & $\mathrm{X}$ & 4.0 & 4.0 & 3.5 & 3.5 & $\mathrm{X}$ & $\mathrm{X}$ & 4.0 & 5.0 \\
\hline Playa Balsa & 4.5 & 4.5 & 5.0 & 4.0 & 4.0 & 4.0 & 1.0 & 1.0 & 2.0 & NA \\
\hline Piriati Embera & 5.0 & NA & 3.5 & 5.0 & 5.0 & 4.0 & $\mathrm{X}$ & $\mathrm{X}$ & 3.5 & 5.0 \\
\hline Punta Valiente & 5.0 & 4.5 & 3.0 & 2.0 & 3.0 & 4.0 & 3.0 & 5.0 & 4.0 & 5.0 \\
\hline Quebrada Cacao & 5.0 & 5.0 & 4.0 & 3.0 & 4.0 & 4.5 & 4.0 & $\mathrm{X}$ & 4.0 & 2.5 \\
\hline Quebrada Mina & 3.0 & 5.0 & 5.0 & 4.0 & 4.0 & $\mathrm{X}$ & 4.0 & 5.0 & 5.0 & 5.0 \\
\hline Rio Bonito & $\mathrm{X}$ & $\mathrm{X}$ & 5.0 & 5.0 & 4.0 & 2.5 & 5.0 & 4.5 & 5.0 & $\mathrm{X}$ \\
\hline Rio Pavo & 5.0 & 5.0 & 5.0 & 5.0 & 5.0 & 5.0 & 5.0 & 5.0 & 5.0 & 5.0 \\
\hline Salto Dupi & 4.0 & 4.5 & 2.0 & 4.0 & 3.0 & 4.0 & 5.0 & 3.0 & 3.0 & 4.0 \\
\hline San Pedro & 4.5 & 3.5 & 4.5 & 5.0 & 5.0 & 4.0 & 4.0 & 4.0 & 4.5 & 5.0 \\
\hline Tamarindo/Zimba & 5.0 & NA & 3.0 & 4.0 & 2.5 & 4.0 & 3.0 & 4.0 & 4.0 & 5.0 \\
\hline Tobobe & 4.0 & 2.0 & 3.5 & 5.0 & 3.0 & 3.0 & 3.0 & 5.0 & 4.0 & $\mathrm{X}$ \\
\hline Valle Risco - Bario Santos & 4.0 & 4.5 & 4.0 & 5.0 & 3.5 & 4.5 & 4.0 & 3.5 & 4.0 & 5.0 \\
\hline
\end{tabular}




\section{Appendix D. History of the System}

\begin{tabular}{|c|c|}
\hline Community & History of System \\
\hline Bahia Azul & $\begin{array}{l}\text { Original system built in } 1996 \text {. In 2006, PCV Adam Valenti used } \\
\text { Waterlines fund to replace the dam for the intake, replace } 1,600 \text { feet } \\
\text { of mainline, and connect } 22 \text { additional houses. }\end{array}$ \\
\hline Cayo Paloma & $\begin{array}{l}\text { Original system built in 1990. In 2005, PCV Matthew Babcock } \\
\text { used } \$ 1,148.90 \text { from Waterlines to construct a 4,000-gallon storage } \\
\text { tank. }\end{array}$ \\
\hline Cerro Iglesia & $\begin{array}{l}\text { Original system built in 1973. Between } 2005 \text { and 2006, PCV Mike } \\
\text { Chapura used Waterlines fund to built two spring boxes, connect } 46 \\
\text { additional houses, replace different sections of the tubes and fix the } \\
\text { damages from the storage tanks. }\end{array}$ \\
\hline Cerro Miguel & $\begin{array}{l}\text { In 2002, PCV Ryan J Gross used } \$ 4,800 \text { from Waterlines to } \\
\text { connect to the existing water system of Quebrada Loro. He also } \\
\text { used this funding to build a spring box to increase the water supply. }\end{array}$ \\
\hline Cerro Puerco & $\begin{array}{l}\text { The original system built in } 1998 \text {. In } 2008 \text {, PCV John Nehls helped } \\
\text { to rehabilitate the system by building a new spring box, improving } \\
\text { the transmission line by installing air release valves and bridge- } \\
\text { crossings, and connecting } 20 \text { additional houses. In } 2009 \text {, a private } \\
\text { contract hired by the representante built another spring box and a } \\
\text { storage tank, and connected additional houses. }\end{array}$ \\
\hline Cerro Venado & $\begin{array}{l}\text { Waterlines helped to build a deep well, a storage tank and the } \\
\text { distribution system, and installed a pump } 15 \text { years ago. In } 2005 \text {, } \\
\text { PCV Kevin Bingley used Waterlines funding to build a spring box, } \\
\text { and installed a solar panel and pump to pump up water to the } \\
\text { existing tank. Waterlines also helped to connect to another source } \\
\text { that could supply the community via gravity but does not provide } \\
\text { enough water during the dry season. }\end{array}$ \\
\hline $\begin{array}{l}\text { Corazón de Jesus } \\
\text { (Akunasadup) }\end{array}$ & $\begin{array}{l}\text { The original water system built in } 2003 \text { by an NGO. The system } \\
\text { consisted of a pump, a two-chamber slow sand filter, and } 5 \mathrm{~km} \text { of } \\
3 \text { " tubes. Within couple of years, the intake of the pump stopped } \\
\text { functioning. In } 2005, \$ 750 \text { from Waterlines solicited by PCV } \\
\text { Melitza Wetzler helped to buy } 3 " \text { tubes to connect to the existing } \\
\text { Narganá water system, which is a community located on the island } \\
\text { next to Corazón. }\end{array}$ \\
\hline El Zapote & $\begin{array}{l}\text { The system was built in } 2003 \text { by PCV Ryan Gross. Waterlines and } \\
\text { USAID funded } \$ 3,300 \text { and } \$ 1642 \text { respectively for the project. }\end{array}$ \\
\hline Junquito & $\begin{array}{l}\text { In } 2006 \text {, PCV Sasha Rao used } \$ 3,750 \text { to build a complete water } \\
\text { system that is currently serving } 11 \text { households. In } 2008 \text {, a private } \\
\text { contractor built another complete system serving } 26 \text { additional } \\
\text { houses. }\end{array}$ \\
\hline La Gloria & $\begin{array}{l}\text { In } 2004 \text {, PCV John Spalding solicited } \$ 3,643 \text { from Waterlines to } \\
\text { build a new spring box and anew storage tank of 50,000 liters, and } \\
\text { connect } 25 \text { additional houses. }\end{array}$ \\
\hline La Pedagoza & $\begin{array}{l}\text { In 2008, PCV Andre Hable solicited } \$ 8,830 \text { from Waterlines to } \\
\text { build a spring box and install over } 3,700 \text { meters of tubing. }\end{array}$ \\
\hline
\end{tabular}


Post-Project Assessment and Follow-Up Support for Community Managed Rural Water Systems in Panama

\begin{tabular}{|c|c|}
\hline Monte Rico & $\begin{array}{l}\text { In } 2007 \text {, PCV David Frodsham used } \$ 6,898 \text { from the Waterlines } \\
\text { fund to build two full gravity-fed aqueducts for the communities of } \\
\text { Monte Rico and Rio Bonito. }\end{array}$ \\
\hline Nudobidy & $\begin{array}{l}\text { In, } 2008 \text { PCV Joe Goessling completed the water system using } \\
\$ 6,800 \text { from the Waterlines fund. The water system consists of }\end{array}$ \\
\hline Nuevo Paraiso & $\begin{array}{l}\text { In 2006, PCV Andrew Parruci used } \$ 3,750 \text { to build two spring } \\
\text { boxes and a 5,000-gallon storage tank. The second storage tank } \\
\text { was never completed. FIS had agreed to provide all the tubes for } \\
\text { the distribution system but they still have not completed their } \\
\text { promise. }\end{array}$ \\
\hline Oriente de Risco & $\begin{array}{l}\text { The water system was completed in } 2004 \text { with funding from } \\
\text { Waterlines. }\end{array}$ \\
\hline Piriati Embera & $\begin{array}{l}\text { The original system built in } 1979 \text { by the Panamanian Government. } \\
\text { The system was rebuilt in } 2002 \text { by FIS for } \$ 150,000 \text {. In } 2007 \text {, PCV } \\
\text { Alan Foster solicited } \$ 11,650 \text { to connect to another source using } \\
6 \mathrm{~km} \text { of } 2 \text { "PVC piping. }\end{array}$ \\
\hline Playa Balsa & $\begin{array}{l}\text { In 2006, PCV Matthew Babcock solicited } \$ 566 \text { to build a private } \\
\text { aqueduct for the family of Ovidio Williams. }\end{array}$ \\
\hline Punta Valiente & $\begin{array}{l}\text { In } 2003 \text {, PCV Danny Hurtado solicited } \$ 3,349 \text { to build a complete } \\
\text { aqueduct for the community of Punta Valiente. }\end{array}$ \\
\hline Quebrada Cacao & $\begin{array}{l}\text { In 2008, PCV's Brandon Braithwaite and Joe Goessling helped to } \\
\text { complete two separate water systems for the community of } \\
\text { Quebrada Cacao. }\end{array}$ \\
\hline Quebrada Mina & $\begin{array}{l}\text { In } 2009 \text {, PCV Julie Herrick solicited } \$ 6,450 \text { from Waterlines to } \\
\text { build a water system for the community of Quebrada Mina. }\end{array}$ \\
\hline Rio Bonito & $\begin{array}{l}\text { In } 2007 \text {, PCV David Frodsham used } \$ 6,898 \text { from the Waterlines } \\
\text { fund to build two full gravity-fed aqueducts for the communities of } \\
\text { Monte Rico and Rio Bonito. }\end{array}$ \\
\hline Rio Pavo & $\begin{array}{l}\text { In 2008, PCV Roanel Herrera completed the Rio Pavo water system } \\
\text { with } \$ 9,220 \text { from Waterlines. }\end{array}$ \\
\hline Salto Dupi & $\begin{array}{l}\text { In 2004, PCV Kate Callaghan solicited } \$ 3,120 \text { from Waterlines to } \\
\text { complete the water system for Salto Dupi. }\end{array}$ \\
\hline San Pedro & $\begin{array}{l}\text { The original water system for the community of San Pedro was } \\
\text { installed in } 1988 \text {. In order to accommodate for the growing } \\
\text { population, in 2006, PCV Patricia Greenburg solicited } \$ 6,080 \text { from } \\
\text { Waterlines to build a spring box, install about one mile of } 2 \text { " tubes } \\
\text { to connect to the existing system and build a 5,000-gallon storage } \\
\text { tank. However, a year after the project was complete, the local } \\
\text { Ministry of Health (MINSA) came in and installed a 3" } \\
\text { transmission line along the same path and constructed a 10,000- } \\
\text { gallon storage tank right next to the tank built a year before. }\end{array}$ \\
\hline Tamarindo/Zimba & $\begin{array}{l}\text { The original system was built over } 20 \text { years ago. The same source } \\
\text { provides water for two communities Tamarindo and Zimba. In } \\
2005 \text {, PCV John Flaherty installed an additional 2" transmission } \\
\text { line connecting the source and the storage tank. In 2006, another } \\
\text { PCV Matthew Rhody built a sand filter and a second 5,000-gallon } \\
\text { storage tank. }\end{array}$ \\
\hline Tobobe & $\begin{array}{l}\text { The community of Tobobe has three separate water systems. In } \\
2006, \text { PCV Matthew Babcock solicited } \$ 1882 \text { from Waterlines to } \\
\text { construct a water system for the Kru-Nikode neighborhood. }\end{array}$ \\
\hline Valle Risco - Barrio Santos & $\begin{array}{l}\text { The water system was completed in } 2005 \text { by PCV Tess Sparks with } \\
\text { funding from Waterlines. }\end{array}$ \\
\hline
\end{tabular}




\section{Appendix E. Summary of Community Visits}

\begin{tabular}{|c|c|}
\hline Community & State of Water System 2009-2010 \\
\hline Bahia Azul & $\begin{array}{l}\text { Although there are } 12 \mathrm{gal} / \mathrm{min} \text { of water entering the storage tank, it } \\
\text { never fills up. There are major leakages in the system. There is an } \\
\text { inequity of flow between the houses and water shortages are } \\
\text { common. }\end{array}$ \\
\hline Cayo Paloma & $\begin{array}{l}\text { The storage tank has leaks in two of the corners as well as where } \\
\text { the outlet pipe is inserted. All the residents have sufficient water } \\
\text { year-round. }\end{array}$ \\
\hline Cerro Iglesia & $\begin{array}{l}\text { Major inequity of flow between the } 127 \text { households connected to } \\
\text { the system. Houses located further away from the source suffer } \\
\text { from frequent water shortages throughout the year and may not } \\
\text { have water for multiple days in a row during the dry season. This } \\
\text { problem is getting worse as the community keeps increasing } \\
\text { rapidly. }\end{array}$ \\
\hline Cerro Miguel & $\begin{array}{l}\text { Rapid population growth in Quebrada Loro caused frequent water } \\
\text { shortages throughout the year. Then a tractor cutting a new road } \\
\text { through Cerro Miguel destroyed tubes connecting majority of the } \\
\text { residents. Today, majority of the water system remains abandoned. }\end{array}$ \\
\hline Cerro Puerco & $\begin{array}{l}\text { Inequity of flow and pressure between the houses. A spring box } \\
\text { built by the contractor is not functioning. The community is happy } \\
\text { with the work done by John Nehls. During the dry season, the first } \\
\text { storage tank is closed at night to allow the tank to fill up. The old } \\
\text { water committee president is accused of misusing the funds and the } \\
\text { leftover materials. }\end{array}$ \\
\hline Cerro Venado & $\begin{array}{l}\text { The solar panel or the pump broke down two years ago. PRODEC } \\
\text { built in a new spring box (although it was not necessary), new tank } \\
\text { for the pump, another tank for the distribution, and installed a } \\
\text { electric pump (there is electricity in the community as of five years } \\
\text { ago). }\end{array}$ \\
\hline $\begin{array}{l}\text { Corazón de Jesus } \\
\text { (Akunasadup) }\end{array}$ & $\begin{array}{l}\text { Although Narganá water system should have enough water to } \\
\text { supply both communities, the residents of Corazón complained } \\
\text { about the infrequent services. The fractions between the two } \\
\text { communities is forcing Corazón to explore options to have their } \\
\text { own separate water system. } 9 \mathrm{~km} \text { of } 6 \text { " PVC tubes serves water } \\
\text { from a river to Narganá. }\end{array}$ \\
\hline El Zapote & $\begin{array}{l}\text { The source output diminishes during the dry season causing } \\
\text { intermittent services. Some residents claim they stopped receiving } \\
\text { water within couple months of finishing the system. The road } \\
\text { construction destroyed some tubes and lower part of the community } \\
\text { no longer receives water from the system. }\end{array}$ \\
\hline Ibiari-Gucamayoi & $\begin{array}{l}\text { Unless there is a long dry spell, which is uncommon in this area, } \\
\text { there is sufficient water for all the users. The spring box is } \\
\text { vulnerable to runoff and there are some leaks. Although the water } \\
\text { committee seems to be well-organized, they are not using glue to } \\
\text { form new joints. }\end{array}$ \\
\hline
\end{tabular}




\begin{tabular}{|c|c|}
\hline Junquito & $\begin{array}{l}\text { The watershed for the aqueduct built with Waterlines fund has been } \\
\text { reforested by a local youth environmental group. Besides some } \\
\text { leaky taps, the system is still in good condition with no major } \\
\text { damages. When a dry spill lasts for multiple weeks, there is a } \\
\text { shortage of water. }\end{array}$ \\
\hline La Gloria & $\begin{array}{l}\text { According to the community members, the storage tank was poorly } \\
\text { built and it was not able to withstand the weight of water when it } \\
\text { was full. The source where the new spring box is also not in use. }\end{array}$ \\
\hline La Pedagoza & $\begin{array}{l}\text { PCV Aaron Wintston, who is currently assigned to the community } \\
\text { will help to build a storage tank. Each house is responsible for } \\
\text { paying for tubes to connect to the mainline. }\end{array}$ \\
\hline Monte Rico & $\begin{array}{l}\text { Since this is a small system serving about } 10 \text { houses, all the } \\
\text { residents always have enough water. There is a leak in the spring } \\
\text { box and it has no tube for breathing. }\end{array}$ \\
\hline Nudobidy & $\begin{array}{l}\text { The water system is still in excellent condition providing enough } \\
\text { water to all users. The water committee has been diligent about } \\
\text { collecting money and maintaining the system. The break-pressure } \\
\text { tank not in use. }\end{array}$ \\
\hline Nuevo Paraiso & $\begin{array}{l}\text { The spring boxes and water tank remain abandoned. The } \\
\text { Panamanian Government will finance a complete new system } \\
\text { including a new storage tank. }\end{array}$ \\
\hline Oriente de Risco & $\begin{array}{l}\text { The original source is no longer in use as all the water leaks from } \\
\text { the bottom of the spring box. The community has connected to } \\
\text { another source with greater volume on their own. There is an } \\
\text { inequity of flow and pressure between houses and houses located in } \\
\text { unfavorable locations suffer from intermittent services. }\end{array}$ \\
\hline Piriati Embera & $\begin{array}{l}\text { There are many leaks in the distribution system especially at night } \\
\text { when the pressure in the system builds up from closed-taps. These } \\
\text { leaks may cause water shortage if it does not get fixed. The } \\
\text { committee did not get sufficient training to operate the volcanic } \\
\text { sand filter with mechanical backwash pump. The break-pressure } \\
\text { tank has no overflow and the foundation is getting carved out. }\end{array}$ \\
\hline Playa Balsa & $\begin{array}{l}\text { The system is working fine but the family has no money saved up } \\
\text { for system maintenance. They would like to have Peace Corps send } \\
\text { them glue and other materials to fix the damages. }\end{array}$ \\
\hline Punta Valiente & $\begin{array}{l}\text { The community suffer from water shortages when it has not rained } \\
\text { for multiple weeks in a row. None of the } 1.6 \mathrm{~km} \text { transmission line } \\
\text { has been buried. The water committee is certified as an official } \\
\text { entity (JAAR) by the Ministry of Health. }\end{array}$ \\
\hline Quebrada Cacao & $\begin{array}{l}\text { Despite some leaky taps and valves, the aqueduct is providing } \\
\text { enough water for majority of the time. When a dry spill lasts for } \\
\text { multiple weeks, the residents must use nearby creek for bathing and } \\
\text { washing clothe. }\end{array}$ \\
\hline Quebrada Mina & $\begin{array}{l}\text { The system is working well up to now. The community members } \\
\text { are not sure if the sources would provide enough water during the } \\
\text { dry season. }\end{array}$ \\
\hline Rio Bonito & $\begin{array}{l}\text { The majority of the houses have not had any water for over a week } \\
\text { at time of visit. The current source dries up during the dry season. }\end{array}$ \\
\hline
\end{tabular}




\begin{tabular}{|l|l|}
\hline Rio Pavo & $\begin{array}{l}\text { The system is working well. The community had used } \$ 1,300 \text { from } \\
\text { the monthly tariffs to buy } 1 \text { ha of land for watershed protection and } \\
\text { they are planning to buy another 4 ha. }\end{array}$ \\
\hline Salto Dupi & $\begin{array}{l}\text { The system provides enough water for all uses for 9 1/2 months out } \\
\text { of the year. Water shortages are common during the dry season. }\end{array}$ \\
\hline San Pedro & $\begin{array}{l}\text { The spring box has a leak. The system provides enough water for } \\
\text { all uses majority of the year except for middle of the dry season. }\end{array}$ \\
\hline Tamarindo/Zimba & $\begin{array}{l}\text { SDR } 41 \text { that should only be used as drainage pipe was used for the } \\
\text { transmission line. As a result, damages among this line is common } \\
\text { especially because these tubes are not buried. There might be } \\
\text { short-circuiting in the sand filter. The community suffers from } \\
\text { intermittent services especially the houses located further down the } \\
\text { line or higher up on a hill. }\end{array}$ \\
\hline Tobobe & $\begin{array}{l}\text { The population of Tobobe is growing quickly. The water is } \\
\text { available for only 15 to 30 minutes in the morning and in the } \\
\text { afternoon when the water tank is opened. Majority of the water is } \\
\text { leaking from the spring box. }\end{array}$ \\
\hline Valle Risco - Bario Santos & $\begin{array}{l}\text { Despite some inequity of pressure and flow, the system provides } \\
\text { enough water to all users throughout the year. }\end{array}$ \\
\hline
\end{tabular}




\section{Appendix F. Recommended Follow-Up for Each Community}

\begin{tabular}{|c|c|}
\hline Community & Recommendations \\
\hline Bahia Azul & $\begin{array}{l}\text { Fix the damages present throughout the distribution system. } \\
\text { Provide additional training to the water committee. }\end{array}$ \\
\hline Cayo Paloma & Fix the leaks in the tank. \\
\hline Cerro Iglesia & $\begin{array}{l}\text { Place flow regulators in houses or sections with disproportionate } \\
\text { amount of pressure. Fix all the leaks present in the system. Form } \\
\text { an agreement with the landowner to protect the watershed. }\end{array}$ \\
\hline Cerro Miguel & $\begin{array}{l}\text { The president of the water committee claims that there is another } \\
\text { source that they could use to build a separate system for Cerro } \\
\text { Miguel. Additional training for the new water committee. Not } \\
\text { recommended for PCV because of Disgruntled local political } \\
\text { leader. }\end{array}$ \\
\hline Cerro Puerco & $\begin{array}{l}\text { If the community wants to utilize the new source installed by the } \\
\text { private contractor, a pressure-break tank must be installed to unite } \\
\text { the flow and another hydraulic gradient calculation must completed } \\
\text { to make sure that water will reach the tank. Flow regulators should } \\
\text { be installed for houses with excessive pressure. Additional training } \\
\text { for the new water committee. }\end{array}$ \\
\hline Cerro Venado & $\begin{array}{l}\text { Water committee training with special focus on pump operation and } \\
\text { maintenance. }\end{array}$ \\
\hline $\begin{array}{l}\text { Corazón de Jesus } \\
\text { (Akunasadup) }\end{array}$ & $\begin{array}{l}\text { The community of Corazón would like to install their own } \\
\text { transmission line from their existing unused sand filter to the dam } \\
\text { where Narganá currently draws its water. A survey should be } \\
\text { completed from the dam to the filter to determine the optimum tube } \\
\text { width and quantity. }\end{array}$ \\
\hline El Zapote & $\begin{array}{l}\text { Training for the water committee. Apparently, there is another } \\
\text { source that could increase the quantity of water available. }\end{array}$ \\
\hline Ibiari-Gucamayoi & $\begin{array}{l}\text { Construct a new spring box especially if the population keeps } \\
\text { increasing. The residents would like to receive more } 1 / 2 \text { " tubes to } \\
\text { connect new houses. }\end{array}$ \\
\hline Junquito & $\begin{array}{l}\text { With the current population growth, the community will need to } \\
\text { connect to another source in the future. }\end{array}$ \\
\hline La Gloria & $\begin{array}{l}\text { Training of the water committee. Currently the committee only } \\
\text { consists of a president. Rehabilitate the storage tank. }\end{array}$ \\
\hline La Pedagoza & $\begin{array}{l}\text { Build a storage tank. Flow-reducers may need to be installed at } \\
\text { certain houses with excessive pressure. }\end{array}$ \\
\hline Monte Rico & Fix the spring box. Training for the water committee. \\
\hline Nudobidy & $\begin{array}{l}\text { For future water committee training in Bocas del Toro, use } \\
\text { Nudobidy as an example of how a water committee should work. }\end{array}$ \\
\hline Nuevo Paraiso & $\begin{array}{l}\text { PCV Guy Litt will be working with the community and the } \\
\text { government agency on the construction of the new system. }\end{array}$ \\
\hline Oriente de Risco & $\begin{array}{l}\text { The community would like to connect to another source. Interested } \\
\text { in receiving another PCV. }\end{array}$ \\
\hline Piriati Embera & $\begin{array}{l}\text { Install a overflow pipe in the break-pressure tank or build a new } \\
\text { one higher up. The president of the committee would like to } \\
\text { receive training on water system maintenance and operation of the } \\
\text { high-tech filter. }\end{array}$ \\
\hline Playa Balsa & $\begin{array}{l}\text { The residents of Playa Balsa would like to build a complete } \\
\text { aqueduct for the whole community }\end{array}$ \\
\hline
\end{tabular}




\begin{tabular}{|l|l|}
\hline Punta Valiente & $\begin{array}{l}\text { The community would like to connect to another source located } \\
\text { right below the current source. There are also some leaks in the } \\
\text { tank that needs to get fixed. }\end{array}$ \\
\hline Quebrada Cacao & $\begin{array}{l}\text { If the population keeps increasing, the main system they may need } \\
\text { to connect to another source. This would mean that the current } 1 / 2 " \\
\text { transmission line would have to replaced with larger tube. The } \\
\text { second water system may need a storage tank in the future. }\end{array}$ \\
\hline Quebrada Mina & $\begin{array}{l}\text { Install control valves throughout the distribution system. Plant } \\
\text { more trees in the watershed of the sources. }\end{array}$ \\
\hline Rio Bonito & $\begin{array}{l}\text { The community will connect to another source with help from the } \\
\text { Ministry of Health. They also expressed interest in receiving } \\
\text { training for water committee. }\end{array}$ \\
\hline Rio Pavo & $\begin{array}{l}\text { The Rio Pavo could be used as a model water committee for future } \\
\text { water committee trainings. The community would like to receive } \\
\text { help on how to install a chlorinator. }\end{array}$ \\
\hline Salto Dupi & $\begin{array}{l}\text { If the population keeps increasing, there is another source available } \\
\text { near the current source. They may need to use larger tubes for the } \\
\text { transmission line. }\end{array}$ \\
\hline San Pedro & $\begin{array}{l}\text { The community would like to use the 2" tubes bought with } \\
\text { Waterlines fund to replace the transmission line from the old } \\
\text { system. They are also meeting to fix the spring box. }\end{array}$ \\
\hline Tamarindo/Zimba & $\begin{array}{l}\text { Install air-release valves in the main line. Install flow-reducers for } \\
\text { houses with excessive pressure. Perform water quality analysis at } \\
\text { the intake and outtake of the sand filter to measure its effectiveness. }\end{array}$ \\
\hline Tobobe & $\begin{array}{l}\text { Repair the spring box. The community is willing to finance part of } \\
\text { the cost. Connect to additional source. }\end{array}$ \\
\hline Valle Risco-Barrio Santos & Install pressure reducers to houses with excessive pressure. \\
\hline
\end{tabular}


Appendix G. Cross Correlation Matrix of Ten Indicators. Prepared by calculating the correlation of each indicator's data set to another indicator's data set. The correlation ranges from +1 (positive perfect linear relationship) to -1 (negative perfect linear relationship).

\begin{tabular}{|c|c|c|c|c|c|c|c|c|c|c|}
\hline & 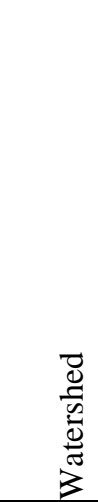 & 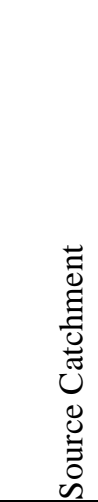 & 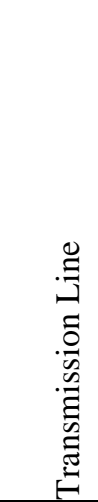 & 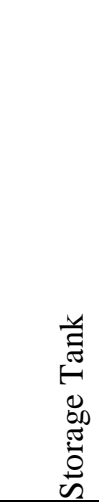 & 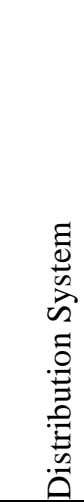 & 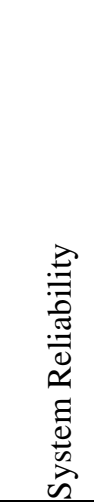 & 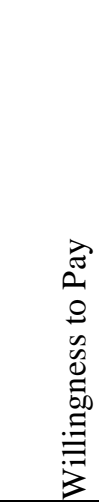 & 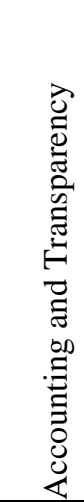 & 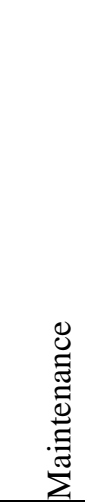 & 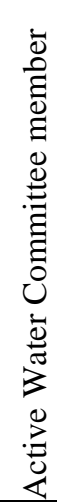 \\
\hline Watershed & $X$ & $X$ & $\mathrm{X}$ & $X$ & $\mathrm{X}$ & $X$ & $\mathrm{X}$ & $\mathrm{X}$ & $\mathrm{X}$ & $\mathrm{X}$ \\
\hline Source Capture & 0.16 & $X$ & $\mathrm{X}$ & $\mathrm{X}$ & $\mathrm{X}$ & $\mathrm{X}$ & $X$ & $\mathrm{X}$ & $\mathrm{X}$ & $X$ \\
\hline Transmission Line & -0.11 & 0.16 & $\mathrm{X}$ & $\mathrm{X}$ & $\mathrm{X}$ & $X$ & $X$ & $\mathrm{X}$ & $\mathrm{X}$ & $\mathrm{X}$ \\
\hline Storage Tank & -0.14 & -0.06 & 0.16 & $X$ & $\mathrm{X}$ & $X$ & $\mathrm{X}$ & $\mathrm{X}$ & $\mathrm{X}$ & $X$ \\
\hline Distribution System & 0.44 & 0.36 & 0.52 & 0.31 & $\mathrm{X}$ & $X$ & $X$ & $\mathrm{X}$ & $X$ & $\mathrm{X}$ \\
\hline System Reliability & 0.47 & 0.25 & 0.37 & -0.22 & 0.66 & $\mathrm{X}$ & $\mathrm{X}$ & $\mathrm{X}$ & $\mathrm{X}$ & $\mathrm{X}$ \\
\hline Willingness to Pay & 0.34 & 0.34 & 0.11 & 0.19 & 0.83 & 0.49 & $\mathrm{X}$ & $\mathrm{X}$ & $\mathrm{X}$ & $\mathrm{X}$ \\
\hline $\begin{array}{l}\text { Accounting and } \\
\text { Transparency }\end{array}$ & 0.27 & 0.26 & -0.04 & 0.14 & 0.33 & 0.07 & 0.50 & $X$ & $X$ & $X$ \\
\hline Maintenance & 0.24 & 0.39 & 0.49 & 0.36 & 0.73 & 0.59 & 0.66 & 0.74 & $\mathrm{X}$ & $\mathrm{X}$ \\
\hline $\begin{array}{l}\text { Active Water Committee } \\
\text { Members }\end{array}$ & 0.14 & -0.32 & 0.01 & 0.27 & 0.02 & 0.31 & -0.17 & 0.26 & 0.09 & $X$ \\
\hline
\end{tabular}

